Document downloaded from:

http://hdl.handle.net/10251/43605

This paper must be cited as:

Serra Lluch, J. (2013). Three color strategies in architectural composition. Color Research and Application. 38(4):238-250. doi:10.1002/col.21717.

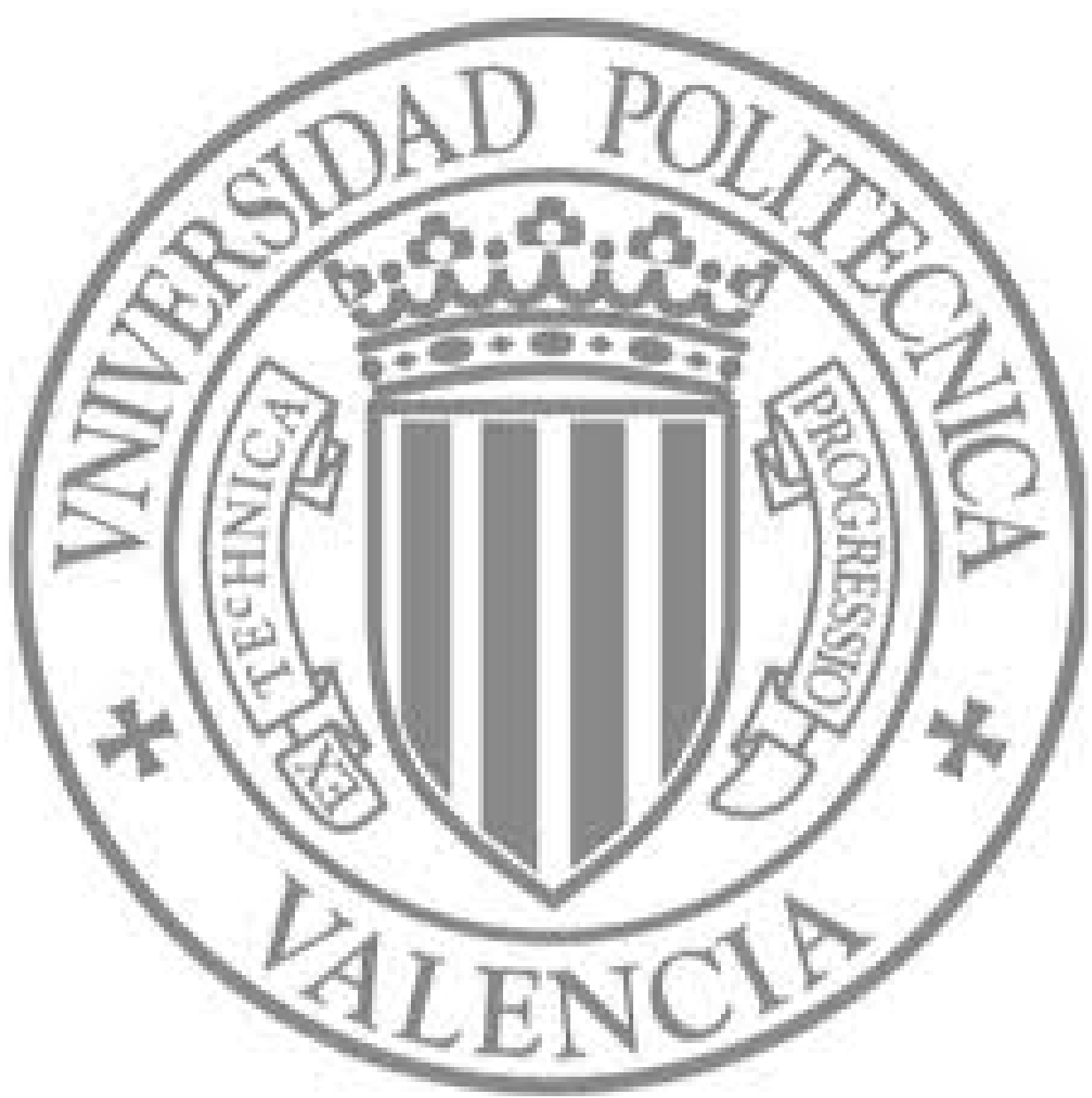

The final publication is available at

http://dx.doi.org/10.1002/col.21717

Copyright Wiley 


\section{Three color strategies in architecture composition}

\begin{tabular}{|c|c|}
\hline Journal: & Color Research and Application \\
\hline Manuscript ID: & Draft \\
\hline Wiley - Manuscript type: & Research Article \\
\hline $\begin{array}{r}\text { Date Submitted by the } \\
\text { Author: }\end{array}$ & $n / a$ \\
\hline Complete List of Authors: & $\begin{array}{l}\text { Serra, Juan; Escuela Técnica Superior de Arquitectura, Expresión } \\
\text { Gráfica Arquitectónica }\end{array}$ \\
\hline Keywords: & Architecture, Color Theory, Art, Comite Espanol del Color, Design \\
\hline
\end{tabular}

THIS IS THE PRE-PEER REVIEWED VERSION OF THE FOLLOWING ARTICLE:

"Three color strategies in architectural composition"

COLOR RESEARCH \& APPLICATION

Volume 38, Issue 4, August 2013, Pages: 238-250, Juan Serra

Article first published online : 13 FEB 2012, DOI: 10.1002/col.21717

Which has been published in final format at:

http://onlinelibrary.wiley.com/doi/10.1002/col.21717/abstract 


\title{
Three color strategies in architecture composition
}

\author{
Juan Serra ${ }^{1}$ \\ ${ }_{1}$ Equipo de Investigación del Color, Instituto de Restauración del Patrimonio, Universidad \\ Politécnica de Valencia, Spain. \\ Keywords: Architecture, Color Theory, Art, Comite Espanol del Color, Design \\ This article is part of the results of the thesis entitled: "The versatility of color in the composition of European \\ contemporary architecture: artistic context, plastic strategies and intentions", which was directed by prof. Ángela Garcia \\ and obtained a European Mention last 19th April 2010.
}

\section{O. ABSTRACT}

We investigate the possibilities that color provides to the architecture composition, the strategies that color enables as a vocabulary for expression. We mostly pay attention to the rules of grammar and syntax of color, and not so much to the semantic meanings, which would depend on observer's multiple interpretations.

After an analysis of color classification systems in architecture proposed by other authors, we infer three main groups of plastic strategies which are not mutually exclusive but complementary: color may interfer with the perception of the visual properties of architectural shapes (I), color may describe the building (II) and color may be arranged for its intrinsic value (III).

Each of these strategies covers a different level of knowledge of the building, which needs both unconscious and conscious mechanisms of identification by the observer. These are the color strategies that the architect may use to express a particular compositive intention.

\section{OBJETIVE}

This research aims to find and organize the plastic possibilities of color in order to achieve certain architectural intentions. This is not a study of the purposes but the resources, the strategies that color enables. This term is pointed out by the British architect Sir Norman Foster, who says that color collaborations with artists "have had a strategic component", so "adding color has brought our thinking into sharper focus" ${ }^{1}$. The architect and color consultant Michael Lancaster also uses the term chromatic strategies when referring to the color schemes for urban ensembles ${ }^{2}$.

Our aim is to study the color capacity to enhance a particular provision of architectural shapes, based on those aspects that are invariant and constitute the rules of grammar and syntax of color. Although color can not be dettached from its semantic, representative, allegorical or symbolic connotations, we focus on its writing rules, on the designer's compositive strategies to achieve goals. We believe these strategies are very usefull for day to day architects work and provide a rational classification system to analyze and understand colored buildings.

\section{STATE OF THE QUESTION}

There are many different systems to classify color in architecture deppending on the discipline used to address the problem ${ }^{3}$. We notice that architects are interested in color related with the composition of buildings, related with the rules that govern a particular shapping, those that pre-occupy and occupy the creative thinking.

The classification system we propose takes into account the results of Swedish architect Karin Fridell, who describes six different reasons (though not exclusive) to color in architecture, apart from those of durability of materials: illusion, allusion, pictures carrying codes, decoration, spatial use of color and functional coloring ${ }^{4}$. All these concepts are 
integrated into our classification, except for the painting for allusion and the pictures carrying codes ${ }^{*}$, as both refer to semantic aspects of color.

We also study the method proposed by Peruvian architect Malvina Arrarte Grau, who identifies seven coloring modes in architecture: plannar, volumetric, layer, structural or syntax, decorative, neutralizing and white ${ }^{5}$. All of them are collected in our classification, except for white and layer. We want to avoid the uniqueness assigned to the white color and not to extend the old debate between white architecture versus colored one. Likewise, the layer color refers to the coloring technique, something that we want to leave aside when considering the plastic strategies.

The adjective decorative color requires further study. It might be considered decorative any unidimensional color provision, without spatial implications. This conception allows to easily understand the difference between the two main color trends in early $20^{\text {th }}$ Century European architecture (aprox. 1920-1960), as described by Swiss historian Verena Schindler ${ }^{6}$. On one hand, there is a two-dimensional/ decorative color legathy of $19^{\text {th }}$ century, which covers the buildings as clothing and comes into being in the theories of G. Semper (1803-1879). On the other hand, there is the three-dimensional/ non-decorative color of modern architecture itself, which is considered from a volumetric point of view and pays attention to the effects of light and shadow. Nevertheless, we consider that nowadays it is insufficient to link decorative with twodimensional coloring, because color in contemporary architecture is often solid or threedimensional, but still an ornament ${ }^{7}$.

To connect decorative with unnecessary is also equivocal, because the pure need leads to retrace the already overcome functionalist architecture period (aprox. 1920-1930). In fact, a non-decorative color could depend on the architect skills to provide any reason in favour of a chromatic provision, exceeding one's own personal preferences. This is the case of Le Corbusier in the Unite d'Habitation (Marseille, 1947), who was reluctant to paint outside concrete brisol-leils with just a decorative criterion, and made an effort to put forward unnecessary functional arguments. Le Corbusier arranges color to mitigate building errors during the construction: "Out of regulatory proportion windows and cement blocks shaped in unadequated molds [...]. That outspoken rebellion of numbers between those harmonic of the Modulor was so distressing for me that arose, at the height of exasperation, the invention of exterior polychromy in the Unitè [...]. Without those mistakes, Marseille's Unitè would never have been colored outside" 8 (fig. 1).

However, our classification requires a third group of plastic strategies, containing those color arrangements which are not related neither with the composition of the shapes, nor with the description of the building. We call it color for its intrinsic value and includes what the authors referred before define as decorative (fig. 2).

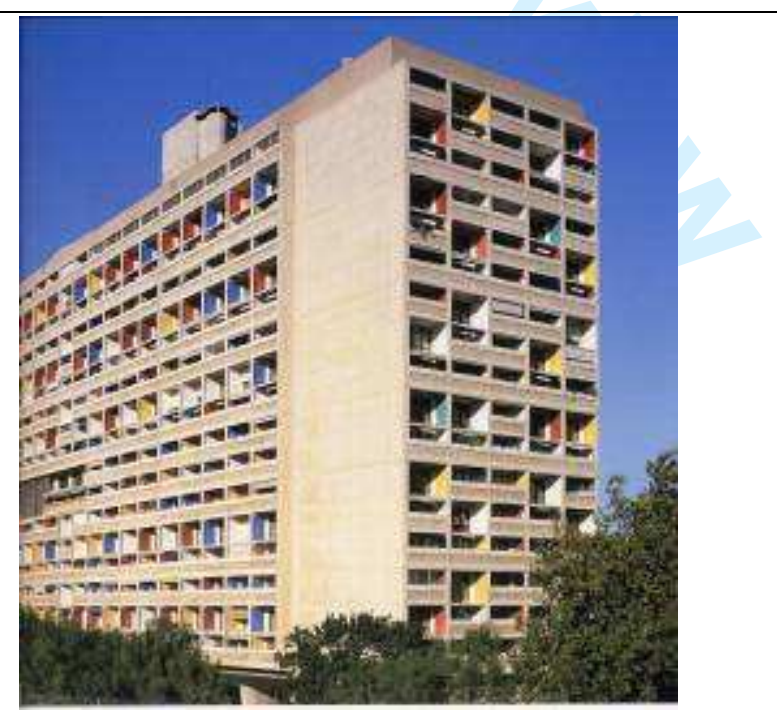

Fig 1. Unitè d'Habitation, Le Corbusier, Marseille, France, 1945-1952. In : Noury L. La couleur dans la ville. Thouard V, editor. $1^{\text {st }}$ ed. Paris: Moniteur (Départment Architecture); 2008. p 43.

\footnotetext{
" Pictures carrying codes are partially taken into account when they describe the function of the building (see chap. 5.3), but not when they refer to other allegorical meanings.
} 


\section{DESCRIPTION OF THE CLASSIFICATION SYSTEM PROPOSED}

The classification system proposed includes three main groups of color strategies: when color interferes with the perception of the visual properties of architectural shapes (I), when color participates in the description of the building (II) and when color is arranged for its intrinsic value (III).

(I) When we study the color strategies to interfere with the perception of the visual properties of architectural shapes, we refer to a starting stage of knowledge with just unconscious identification mechanisms. In this first level, our intelligence organizes stimuli from the physical world by means of cognitive schema which are in common to any observer without pathologies. These schema were studied by the Gestalt psychology school [Max Wertheimer (1880-1943), Wolfgang Köhler (1887-1967), Kurt Koffka (1886 - 1941), Kurt Lewin (1890-1947), etc], and later developed by iconological critics after World War II [E. Panofsky (1892-1968), R. Wittkower (1906-1971), E. Gombrich (1909-2001), R. Arnheim (1904-2007), etc.].

(II) When we study the color strategies to describe the building, it is necessary an active participation of the observer in a conscious level of thought. Color transmits coded information to be interpreted.

(III) When color is performed by its intrinsic value we just attend to its plastic interest. Color improves the appearance of architecture without special attention to neither formal nor functional requirements.

It should be emphasized that this classification is not exclusionary and a particular architectural intention will usually require the simultaneous use of more than just one isolated strategy.

\begin{tabular}{|c|c|c|c|c|c|}
\hline \multicolumn{6}{|c|}{ Comparative among different color classification systems by authors } \\
\hline \multicolumn{3}{|c|}{ J. Serra } & K. Fridell & M. Arrarte Grau & V. Schindler \\
\hline \multirow{6}{*}{$\begin{array}{l}\text { Estrategie I: } \\
\text { Color interfers } \\
\text { with the } \\
\text { perception of the } \\
\text { visual properties } \\
\text { of architectural } \\
\text { shapes }\end{array}$} & \multirow{3}{*}{ Geometry } & $\begin{array}{l}\text { Mimicry/ } \\
\text { Singularity }\end{array}$ & \multirow{6}{*}{$\begin{array}{l}\text { Painting for illusion } \\
\text { Spatial use of colour }\end{array}$} & Neutralizing & \multirow{8}{*}{ Volumetric sense } \\
\hline & & $\begin{array}{l}\text { Integration/ } \\
\text { Disintegration }\end{array}$ & & Plannar/ volumetric & \\
\hline & & $\begin{array}{l}\text { Geometric } \\
\text { distortion }\end{array}$ & & & \\
\hline & Dimensions & & & & \\
\hline & $\begin{array}{l}\text { Visual } \\
\text { weight }\end{array}$ & & & & \\
\hline & Texture & & & & \\
\hline \multirow{2}{*}{$\begin{array}{l}\text { Estrategie II: } \\
\text { Color describes } \\
\text { the building }\end{array}$} & Functional & & Funtional coloring & \multirow{2}{*}{ Structural or syntax } & \\
\hline & Formal & & $\begin{array}{l}\text { Painting for allusion } \\
\text { Carrying codes }\end{array}$ & & \\
\hline \multirow[t]{2}{*}{$\begin{array}{l}\text { Estrategie III: } \\
\text { color is arranged } \\
\text { for its intrinsic } \\
\text { value }\end{array}$} & & & Painted decorations & Decorative & $\begin{array}{l}\text { Textil or decorative } \\
\text { sense }\end{array}$ \\
\hline & & & & $\begin{array}{l}\text { Color layer } \\
\text { White color }\end{array}$ & \\
\hline
\end{tabular}

Fig. 2. Table comparing the color classification systems used by different authors, with respect to the one adopted in our research. 


\section{ESTRATEGY I: COLOR INTERFERS WITH THE PERCEPTION OF THE VISUAL PROPERTIES OF ARCHITECTURAL SHAPES}

\subsection{Justification of the subcategories}

Our intelligence unconsciously organices the electromagnetic stimuli of the physical world and interprets them as color. There are some particular aspects involved in that process such as the visual memory (which anticipates, uses information already known and recognizes the perceived reality) ${ }^{9}$, the mood, the cultural conditioning, the environment, etc ${ }^{10}$. But it also involves perceptual preconceptions, common to any observer without pathologies, which are interesting for our investigation. The Gestalt demonstrated that we have globalizing perceptual systems, which integrate the fragments we extract from reality in a priori structures, governed by a set of laws (law of closure, law of proximity, law of symmetry and law of continuity). The problem is that those Gestalt's experiences and examples are mostly related to two-dimensional shapping, as it is pointed out by the perception psychologist James J. Gibson (1904-1979), when addressing the study of space throughout art's history in his book The Perception of the Visual World (1950).

German psychologist Rudolf Arnheim (1904-2007) uses Gestalt principles to interpret the artwork ${ }^{11}$, but continues to refer primarily to two dimensions. His thinking is based on the grammatical aspects of the perception of shapes: the law of balance, movement, depth, the visual weight of objects, etc.

Hawaiian architecture professor Francis D. K. Ching (1947-) transfers Arnheim's approach into architecture and proposes eight visual properties for shapes: the outline, size, color, texture, position, orientation and visual inertia ${ }^{12}$. We rely on them to develop our own classification, considering that color may interfere with the assessment of the size of the shape, its (visual) weight, geometry and texture ${ }^{\dagger}$. We are interested in how color influences the visual perception of these physical properties, not the real ability to change them ${ }^{\ddagger}$.

\subsection{Color interferes with the perception of the geometry of architecture}

We consider that color may interfere with the perception of the geometry of the architectural object in three ways. The first one concerns the relationship between object and environment, and allows the extreme positions of mimicry and singularity. The second concerns the relationship between the parts and the whole, and allows the integration or disintegration. The third refers to the geometric characteristics of the object and allows the geometric distortions.

\subsubsection{Mimicry/ Singularity (in relation with the environment)}

The identification of a building in an environment is governed by the law figurebackground, which has been studied by many psychologists as Danish Egar Rubin (1886-1951) or the German Rudolf Arnheim. As we have a binary perception, we see the buildings as figures cut out on surrounding surfaces or backgrounds, something facilitated by several factors: its smaller size, closed contour, the more textured, bottom position in the composition, the simplicity of its shape and symmetry, convexity versus concavity and, of course, the colors. Color can help to visually distinguish an object that is understood as a figure over another or

$\dagger$ It is beyond the scope of this research to study the ability of color to interfere on the chromatic parameters of the surrounding colors, or on its own ones, with respect to its extension and observation distance.

To deepen in the first case, refer to: Albers J. La interaccion del color. Madrid: Alianza, 1982.

To deepen in the second one, refer to: Fridell Anter K. What colour is the red house? Perceived colour of painted facades. $1^{\text {st }}$ ed. Stockholm: Royal Institute of Technology, School of Architecture, Department of Architectural Forms, 2000.

$\ddagger$ Color can truly change some physical properties of bodies like their temperature. See: Gatz, K. [Architektur-Farbig] Colour and Architecture. London: Batsford; 1967. p 9. 
§ Le Corbusier, "Le Lait de Chaux: La Loi Du Ripolin (A Coat of Whitewash: The Law of Ripolin)", The Decorative Art of Today, translated by James I. Dunnett (London: The Architectural Press, 1987) First published as L'Art décoratif d'aujourd'hui (Paris: Editions Crés, 1925)

** "Das Prinzip der Bekleidung" in Neue Freie Presse, Viena, 4th September, 1898. In: Loos A, Quetglas J. and Opel A. Escritos 1897-1909, pp. 151-157.

others that are understood as background. The hue, chroma and brightness of color can help or hinder this interpretation that reaches two extremes: mimicry, when figure and background are not distinguished, and what we call singularity, when both reach their maximum contrast.

Instead of architectural mimicry Le Corbusier talks about architectural camouflage, which is to use color to "massacre the volume, the form, to completely alter the notion of silhouette" 13 . The French term camoufler also means disguise, a sense that the architecture critic M. Wigley links to the use of white in Purist architecture ${ }^{14}$. Specifically, he argues that the "Law of Ripolin"§ that Le Corbusier formulates in 1925 is a continuation of "The principle of cladding" by Adolf Loos (1897-1909), and also the "Principles of dressing" formulated in the mid-nineteenth century by Gottfried Semper (1803-1879).

To avoid a terminological conflict, we use the term mimicry, which has no military connotations and corresponds to the defense mechanisms used in the natural kingdom. Mimicry in architecture is provided to rid anything that is visually disturbing, to mitigate the visual impact of large buildings with inadequate sizes with respect to the environment. Sometimes architects want the building to disappear, and the environmental qualities of the landscape to prevail (eg. ThyssenKrup AG Feuerbeschichtungsanlage FBA 8, Dortmund, Germany, 2003) (fig. 3).
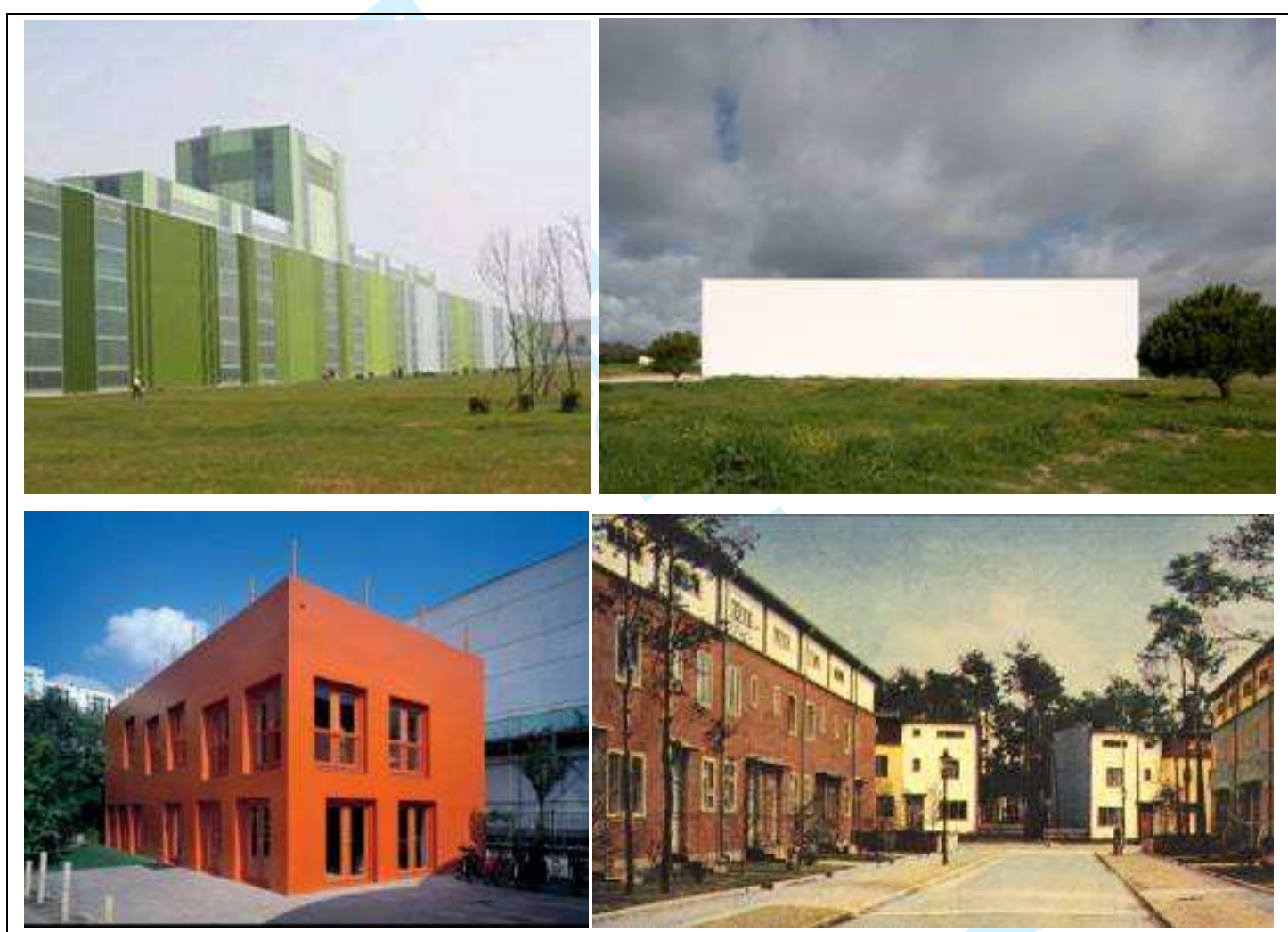

Fig. 3. ThyssenKrupp AG Feuerbeschichtungsanlage FBA 8. Friedrich Ernst von Garnier, Dortmund (Germany), 2003. Courtesy Stucio Ernst Von Garnier <http://www.studiovongarnier.de/>

Fig. 4.Guerrero House. Alberto Campo Baeza, Zahora, Cádiz (España), 2005.

In: < http://arquitecturamashistoria.blogspot.com/2008/04/la-idea-construda-de-campo-baeza-un.html>

Fig. 5. Studio Thonik or the Orange House. MVRDV arquitects, Ámsterdam (Holanda), 1998-2001. Courtesy MVRDV architects <http://www.mvrdv.nl/>

Fig. 6. Siedlungen Onkel Tom's Hutte. Argentinische Alleé, B. Taut, Zehlendorf (Germany), 1926-1931. In: Taut B. and Nerdinger W. Bruno Taut: 1880-1938. Milano: Electa, 2001.

Sometimes color aims to single out and highlight the architecture within a more or less uniform context. It is usual in degraded environments to try to draw attention onto certain buildings and distract from anything less interesting. The challenge is to enhance the landscape by working individually, without falling into the trap of those buildings that Spanish architecture 
critic JM Monater calls autistic monads, which are completely unrelated with the environment ${ }^{15}$. These color arrangements are booming at present and often serve to propaganda, advertising or different types of identity intentions. White is sometimes used with these wills, as it performs the purity of abstract-minimalist architecture objects (eg. Guerrero House, A. Campo Baeza, Cádiz, España, 2005) (fig. 4). Other times, the singularity is reached with very chromatic colors, which can be extremely controversial and convert the buildings into authentic "advertising signs", as described by Dutch architects MVRDV speaking of the Studio Thonik (Amsterdam, 1998-2001) (figs.5): "It was amazing that a color of one house can lead to such attention: architecture works! ${ }^{16}$.

To use color to single one's own home is rooted in the origins of human civilization ${ }^{17}$. Many Mediterranean villages performed brighty different colors on facades, for fishermen to recognice their home from the sea, but the singularity of each property was produced in a chromatic context that finally resulted a harmonic set ${ }^{18}$. This need has also been transferred to the massive housing construction, where color is used to link inhabitants with architectures. In this field it highlights the Berliner Siedlungen developed by B. Taut after the World War II (Onkel Tom's Hute, Zehlendorf, etc.) (fig.6), or so many examples of social housing dwellings during the seventies (eg. T. Taveira in Lisbon).

Between mimicry and singularity there are intermediate positions in which architecture establishes a dialectical relationship with the environment not entailing a color submission, neither a color imposition. It is characteristic of contemporary architecture to "take into account the environment but not to be contextual", to "give a non-friendly response to the environment, although it is taken into account", as ensures the Iraqian architect Zaha Hadid (1950-) when talking about her buildings ${ }^{19}$. Something similar states the German architect Louisa Hutton: "I do not think that there is necessarily a contradiction between a strong presence and working with the context". To what Matthias Sauerbruch adds: "The buildings that we have built do stand out as individual objects, but they have been generated in response to observations of the immediate reality that we find at a particular location" ${ }^{20}$. This is the case of the GSW Headquarters Building in Berlin (fig. 7), where the form is linked to the modern architecture of Western Berlin, while the red color of the curtain wall matches with the rooftops of Eastern Berlin, providing different color treatments for each facade according to its orientation.
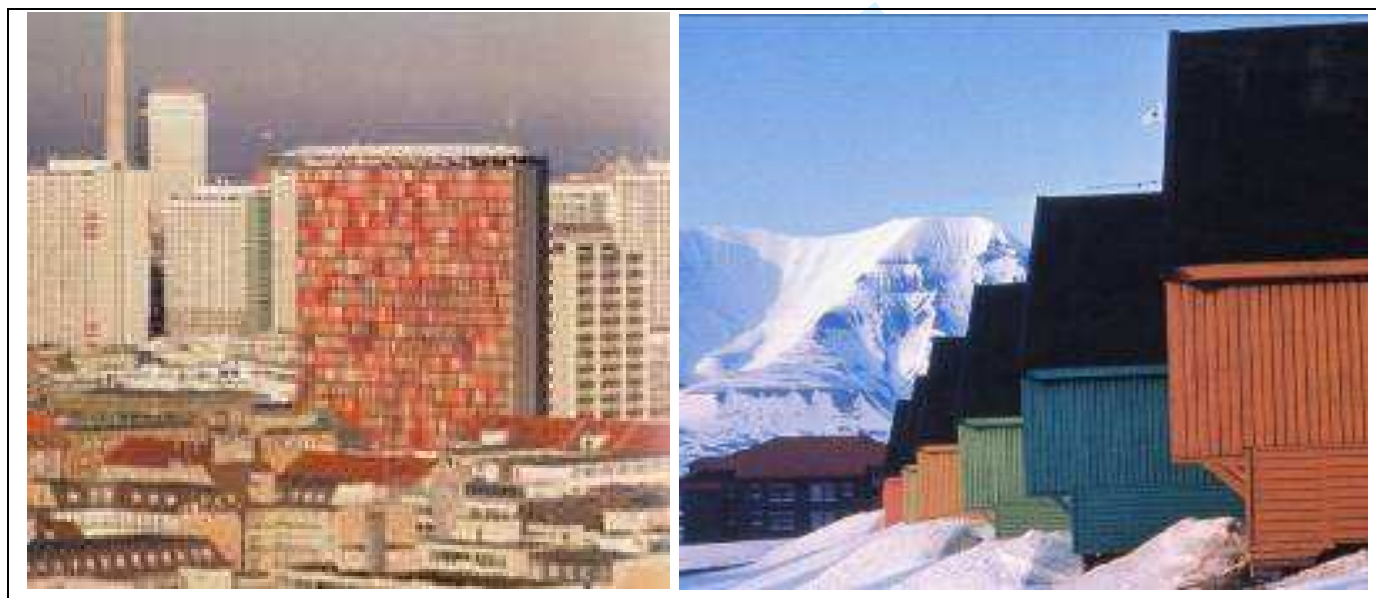

Fig. 7. GSW Headquarters, Sauerbruch \& Hutton architects, Berlín, 1991-1999. Courtesy Stucio Sauerbruch \& Hutton <http://www.sauerbruchhutton.de/>

Fig. 8. Longeyearbyen Project, Grete Smedal, Longeyearbyen (Sweden), 1981. In: Porter T and Mikellides B, editors. Colour for architecture today. London: Taylor \& Francis; 2009. p 77.

There exist exemplary colored architectures referring to the attention payed to the natural landscape, as it is the color project for Longyearbayen (Grete Smedal, Sweden, 1981) (fig.8). Located almost at the North Pole, with three months with total darkness and three months with midnight sun, Smedal wondered "Should one attempt to hide the man-made structure in this setting, or was a distinct contrast appropriate? ". Unable to mimic in every condition all along the year "the decision was made to enter into a dialogue with nature. In other words, to let the man-made structures define themselves with their own characteristic colour scale -inspired from, but not imitating, the colours nature" ${ }^{21}$. It forms an artificial colored landscape which does not smother the exceptional natural environment but dialogues with it, establishing a relationship of equality and respect. 


\subsubsection{Integration/ Disintegration (in relation with the components)}

Different elementary components of the form can be perceived as a unit by color (integration) or conversely, express or reinforce their autonomy (disintegration).

The law of continuity described by the Gestalt states that "when several objects have the same properties [color] but are far in between, they are interpreted by our intellect as forming a single group, whereas if they posses unequal properties [colors], they are perceived as autonomous or independent" ${ }^{22}$. So the maximum chromatic integration is achieved with the monochromy, that strengthens the unitary aspect of architecture and prevents a more detailed description of its components (eg. Blue House, F. Hoffmann, Amsterdam, 2004-2006) (fig. 9) ${ }^{23}$.

Disintegrate means "to separate the various elements that form a whole" $\mathrm{ft}$ and may have different degrees of intensity until to reach a "total breakdown of the object", something difficult to achieve if color is not accompanied with a fragmentary formal composition. These two possibilities of disintegration, to separate and break, are exemplified in the work of Le Corbusier and T. G. Rietveld (1888-1964), respectively.

At Schroeder's House (Utrecht, 1924), Rietveld arranges color to break the enclosure of the space and dissolve the boundaries between interior and exterior. Color frees the components of the spatial box, which is not a closed prism anymore, but the encounter of independent planes and edges. Le Corbusier, however, used in Vilea La Roche Jeanerette a chromatic composition that aims to introduce tension, but without breaking the spatial box: "The wall plane as a carrier of color may have certain autonomy, but it remains a component of an intact space" 24 . Paradoxically, Le Corbusier many times uses color disintegration to reinforce the architectural volume and not to break it, clearly distancing of Neoplasticism, as we will see later in Ville Saboie.

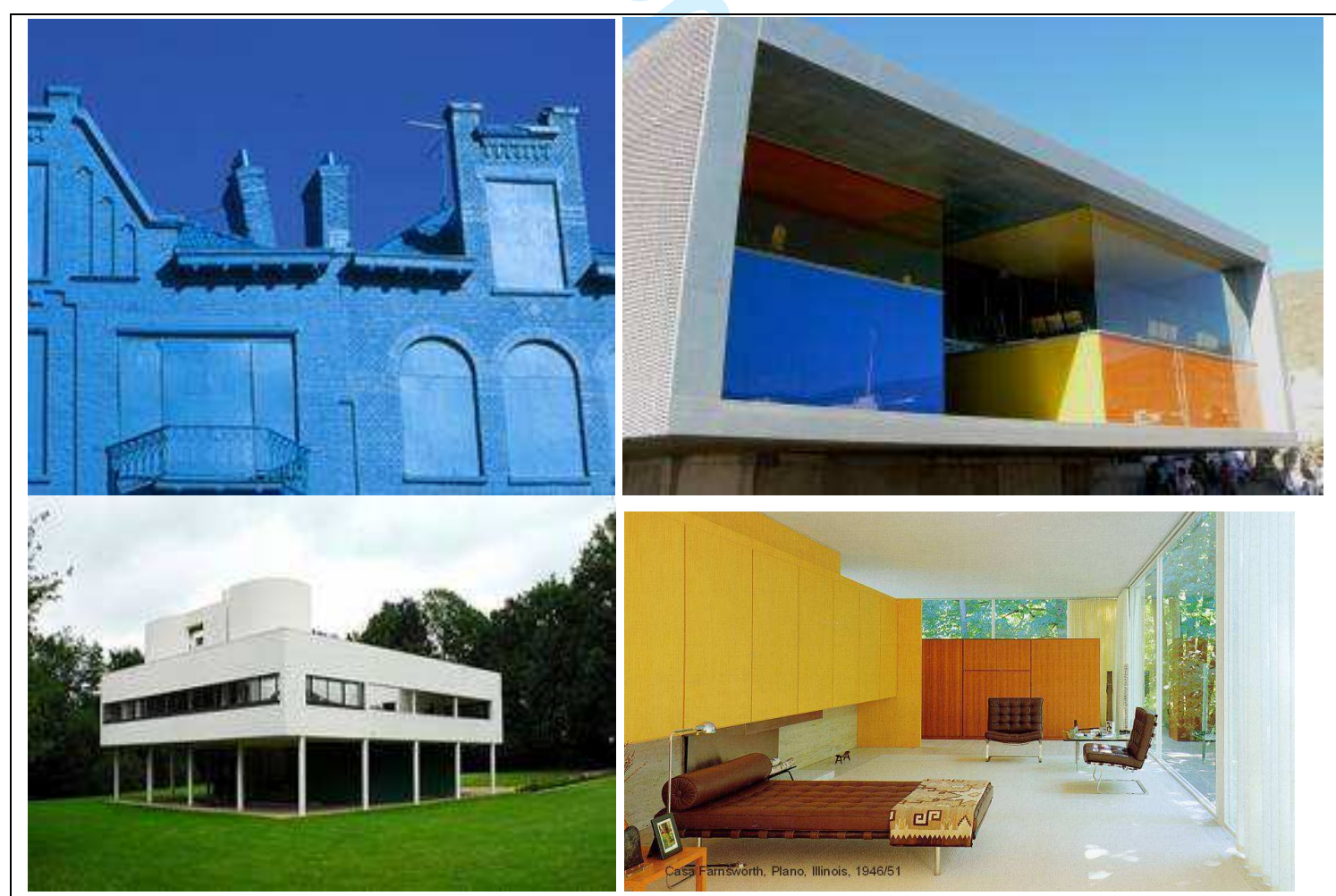

Fig. 9. Beukelsdijk, Florentijn Hoffman, Rotterdam (Holland), 2004-2006. In <http://www.florentijnhofman.nl/> Fig. 10. Scenic Space, MGM arquitects (José Morales, Sara Giles and Juan González), Nijar, Almería (Spain), 19982006. Photo by author.

\footnotetext{
${ }^{\dagger \dagger}$ Dictionary of the Royal Academy of Spanish Language. Translated by the author.
} 
Fig. 11. Ville Saboye. Le Corbusier, Poissy (Francia), 1929-1931. Detalle de la planta baja de la villa, coloreada de verde para confundirse con el contexto. In <http://www.flickr.com/photos/yisris/267935008/>

Fig. 12. Farnsworth House, Mies van der Rohe, Piano, Illimois (USA), 1946-1951. In: Blaser W. Ludwig Mies Van Der Rohe. Barcelona: Gustavo Gili, 1991.

Mies Van der Rohe (1886-1969) himself used the disintegration resource to transform walls and floor structures into separate planes, by color. His famous Farnsworth House (Piano, Illimois, USA, 1946-1951) (fig. 11) is a large white pavilion, abstract and isotropic, with wood furniture in different hues that distinguish from the container prism by color. There are many other contemporary examples, such as the Scenic Space in Níjar (MGM architects, Spain, 1998-2006) (fig. 10) or the Cultural and Congress Center in Lucerne (Jean Nouvel, Switzerland, 2000).

It should be noted that color disintegration does not necessarily involve greater disorder in architectural composition. In fact, Le Corbusier uses it to introduce order in his buildings, to recover the purity of shapes. This happens in his famous Ville Saboie (fig. 11), where the ground floor is painted green, to enhance and dettach the upper white box. As Le Corbusier states, polychromie may "destroy the pure form of an object and [...] allow one to appreciate in one volume only what one wishes to show" 25.

\subsubsection{Geometric Distortion}

Color distorts the geometry when there is a discrepancy between the real shape of the object and the one that observer perceives: straightness/ curvature of the edges, flatness/ concavity/ convexity of the planes, orthogonality between faces, two-dimensionality/ threedimensionality, etc. The distortion is the result of the conflict between the color scheme perceived and the one expected.

The color distortion may be achieved by an inconsistent provision of color brightness. Such is the case of the facade of the Depuratore Sud de Milano (J. Tornquist, Italy, 2004) ${ }^{26}$ (fig. 13), where the color gradations produce that a smooth facade is perceived as warped. Color introduces a new rythm on a wall that was too homogeneous and now gets movement. On the chimney of the Termoutilizattore in Brescia (J. Tornquist, Italy, 1997-1998) (fig. 14), this dynamic occurs vertically and looks like a straight prism subjected to a twisting motion by effect of color.
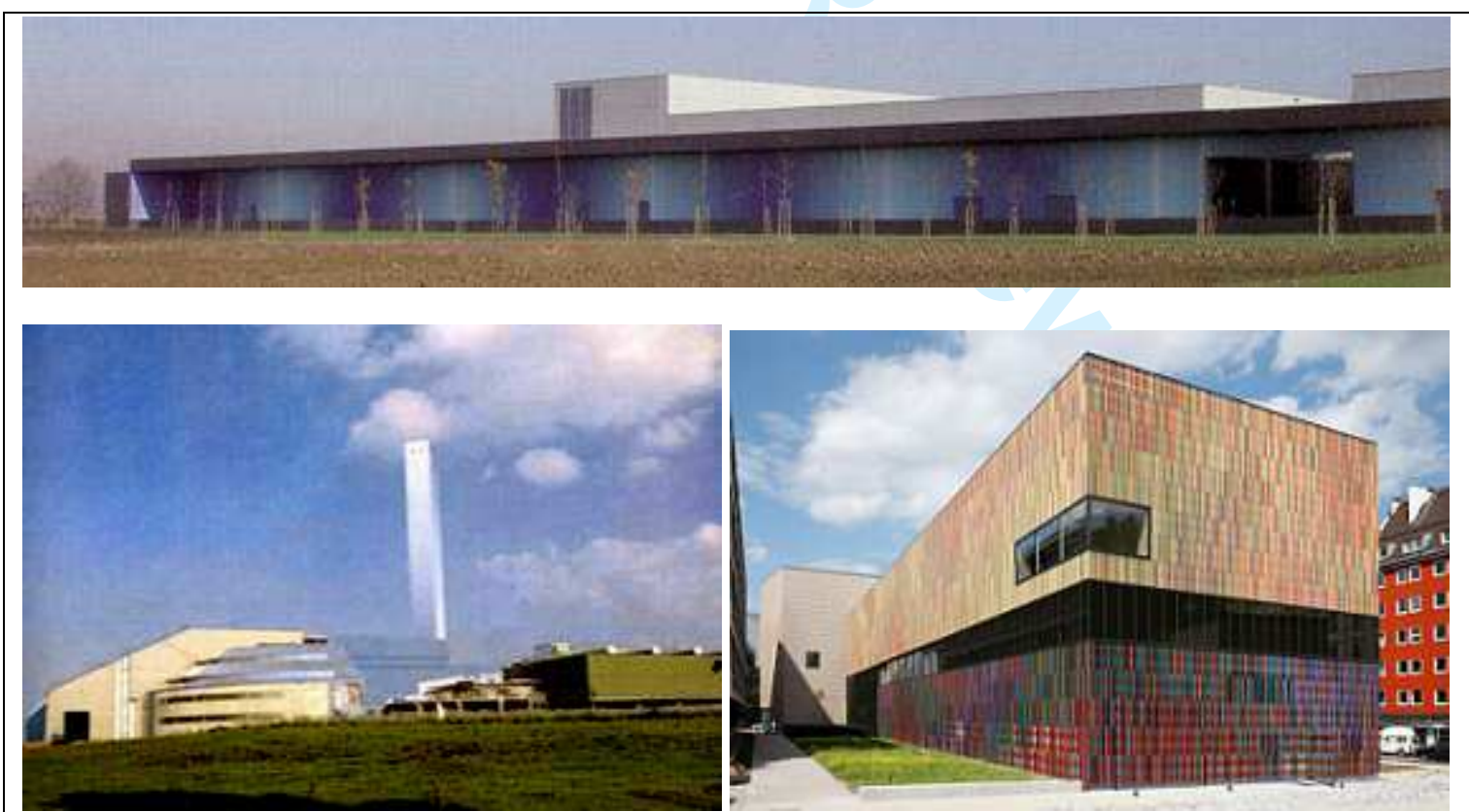

Fig. 13. Depuratore Milano Sud, Jorrit Tornquist, Milano, 2004. In: Tornquist J. Colore e luce: Teoria e Pratica; $3^{\text {rd }}$ ed. Milano: Istituto del colore, 2005. p 306.

Fig. 14. Project Termoutilizzatore di Brescia, Jorrit Tornquist, Brescia (Italy), 1997-1998. In: Tornquist J. Colore e luce: Teoria e Pratica; $3^{\text {rd }}$ ed. Milano: Istituto del colore, 2005. p 109.

Fig. 15. Brandhorst's Museum, Sauerbruch \& Hutton, Munich, 2002-2007. In <http://blog.bellostes.com/> 
The arrangement of color patterns inconsistent with the real geometry, or just patters which are complex and difficult to aprehense, also distort the geometry. Swirnoff says: "When the form of a surface is neither modular nor repeated, clues to form are very ambiguous. As a consequence, this model is radically altered in its appearance by light or by a shift in the observer's position" ${ }^{27}$. This happens in the Brandhorst Museum Collection (Sauerbruch \& Hutton, Munich, 2002-2007) (fig. 15) with separated colored ribbons over a colored background. The pieces seem to move, the edges are blurred and confused, the surfaces seem to loose the smoothness and finally, the geometry of the building distorts. To this effect contribute different color phenomena: simultaneious contrast, Bezold-Brücke Effect ${ }^{\ddagger \ddagger}$, Abney effct ${ }^{\S \S}$, etc.

\section{3. Color interfers in the dimensions of the volume/ space}

Polychromie may cause space/ volume contradictions between its real and apparent dimensions. Color interferes with the proportion of the object (height, width, and length), its measures related to a reference (scale) and its separation from other objects (distances).

Color design manuals in architecture often review these qualities. "A high ceiling and a wall that seem very distant look, respectively, lower and closer if they are painted in a warm shade" ${ }^{28}$. In addition, each color corresponds to a spatial distance from the observer as "color (hue) is inherently spatial, and each spectral hue differs in its spatial nature" ${ }^{29}$. However, not only every hue is related to a visual distance but every distance changes the perception of the hue. Dr. Anders Hard describes it when observing the leaves in a forest at different distances, which change color from green to blue ${ }^{30}$. Le Corbusier states "blue-space, red-fixity of the plan" and gives the short wavelengths the capacity to "give dimension, make an atmosphere, distance the wall, make it imperceptible, remove its quality of solidity by interposing a certain atmosphere"; whereas long wavelengths can "fix the wall, affirm its exact position, its dimension, its presence" ${ }^{31^{* * *}}$.

This way we may understand the color arrangement in the Quartiers Modernes Frugés (Le Corbusier, Pessac, France, 1925) (fig. 16), where color is provided to give width to a rectangular block courtyard that was too small: "We break the enclosure, by painting in blue the houses A [...]; this barrier of houses then collapses towards the horizon. But in order that the outcome be effective we insist on fixing the two lateral sides of the enclosure, to the left and to the right; we paint these B groups pure burnt Sienna earth (dark). The result is conclusive" ${ }^{32}$.

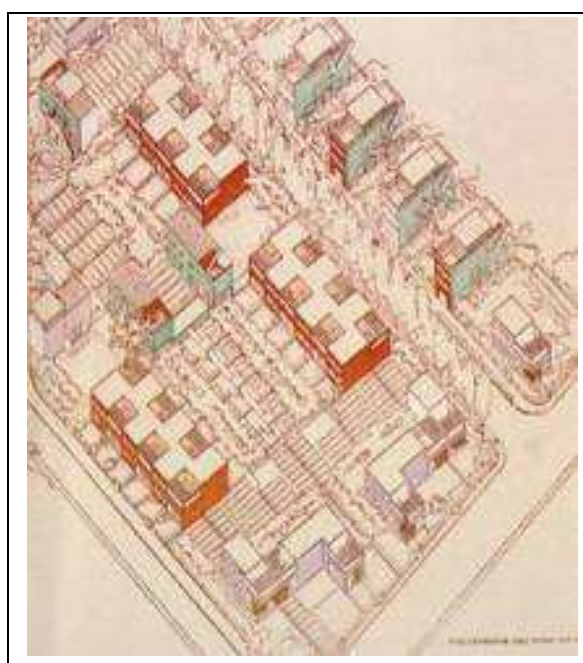

Fig. 16. Quartier Modernes Frugès, Le Corbusier, Pessac (France), 1924-1926. In : Noury L. La couleur dans la ville. Thouard V, editor. $1^{\text {st }}$ ed. Paris: Moniteur (Départment Architecture); 2008. p 46.

\footnotetext{
${ }^{\ddagger \ddagger}$ Bezold-Brücke effect is produced when there are two color stimuli with the same wavelength, but with different intensity (brightness) that produce the perception of different hues.

$\$ \S$ Abney effect is produced when there are two color stimuli with the same dominant wavelength, but with different chroma that produce the perception of different hues.

${ }_{* \star \star}$ Dr Nicholas Humphrey points out some important variables in the illusion of depth generated by colors: the chromatic aberration (SH Bartley, 1958), the figure-ground interaction (W.H. Ittelson, 1960), and brightness, although some experiments contradict the sense of depth related to white (R.M. Hanes, The long and short color distance, 1960). Humphrey N. The effect of colour on our perception of space. In: Porter T and Mikellides B, editors. London: Studio Vista; 1976. p 100.
} 
Brightness of color is very important in depth perception of a space. Under scotopic vision conditions, brighter colors come forward to the observer, whereas under photopic, brighter colors recede. As the president of the Association of Colour Consultant/ Designers (AICC), Frank Mahnke states: "Lighting is one of the most important factors in our perception of openness in interior spaces. Light or pale colors recede and increase the apparent room size, as do cooler colors and smaller patterns. Dark or saturated hues protrude and decrease the apparent size of a room. [...] A high illumination level will enlarge the appearance of volume, whereas a low illumination will diminish it" ${ }^{33}$. Prak also describes how "the mountains are distant because they are light in tone" ${ }^{34}$. Other researchers such as psychologist C. C. Liebmann, or Ittelson and Kilpatrick ${ }^{35}$ studied the importance of light in the perception of the depth of color. Indeed, the American professor Mary C. Miller demonstrated experimentally that the sense of depth in a room can be altered with a proper arrangement of white and black ${ }^{36}$.

In any case, we must bear in mind that color has little influence in the perception of depth as it involves many other variables such as color contrast, overlapping, size, parallax, and visual focus ${ }^{37}$.

\section{4. Color interfers in the visual weight of architecture}

The visual weight of architecture is the evaluation of the force of attraction between a building and the earth, done by an observer. The color does not alter the real value of the mass of the building, but its subjective assessment, its sense of lightness or heaviness. This assessment is linked to the size of the volume (I), its compactness (II) and materiality (III), and is based on our own real experience with the physical weight of other objects. So a small body, transparent, with many gaps, or a material that we recognize as lighty, is visually perceived to be light (fig. 17).

Lightness is achieved by interfering with the color on the three variables mentioned: (I) reducing the size either by altering the perception of size (see chap. 4.3), either fragmenting chromatically (see chap. 4.2.2); (II) altering its compactness by confussing chromatically with the environment (see chap. 4.2.1); (III) modifying its materiality by interfering chromatically in the texture of the object (see chap. 4.5).

The British Standards Institution (BSI) defines the term Apparent Weight of color to explain why on the same conditions of value and chroma, yellow family shades seem not to be equivalent to other colors families of the visible spectrum. The yellow light should increase to reach an equivalent apparent weight.

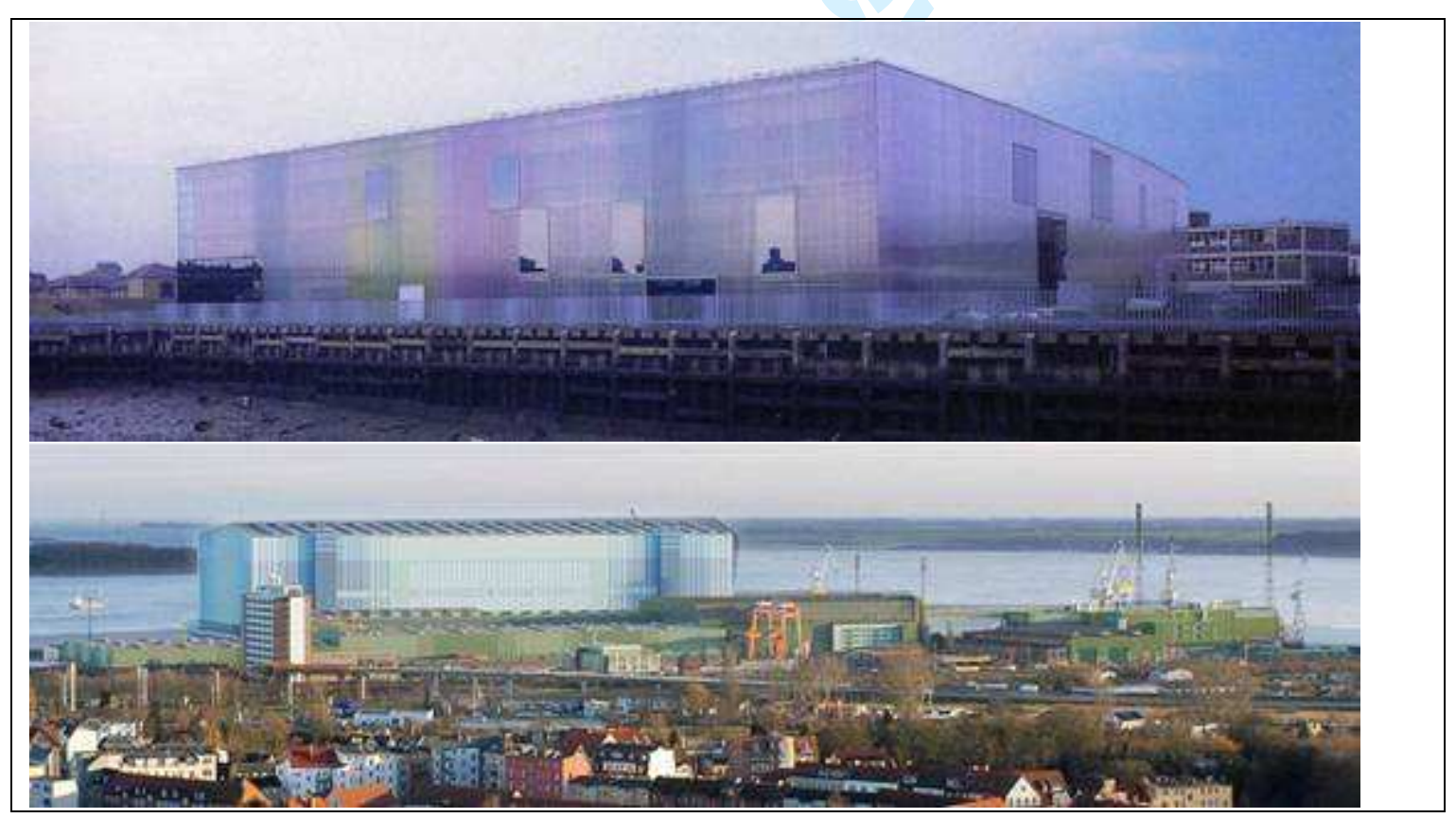


${ }^{\mathrm{ttt}}$ It is no coincidence that this proposal to be developed by an architect who studied in Milano, the city that guards the extraordinary Cenácolo by Leonardo da Vinci, and his Atlantic Codice. the weight of objects. Authors such as P. J. Hayten in the sixties, or F. Waldron in the seventies ${ }^{38}$ state that "the light warm colors, and white, seem to have less weight than the dark cold colors and black. [So] A black painted box gives the impression that it is much heavier than other white-painted " 39 . F. Mahnke also assures that "darker colors appear heavier, whereas lighter and less saturated (pastel) tones seem less dense. If the hues are of the same value and intensity, the tendency is to perceive the warmer hues as heavier " 40 . Le Corbusier agrees and ensures that blue "removes its quality of solidity by interposing a certain atmosphere" while red "affirms the presence" ${ }^{41}$. The Italian architect Piero Bottoni refers in a very specific way to the alteration of the visual weight of the form by color. In his manifesto "Cromatismo Architettonico" (Milano, 1927), he demonstrates that, depending on how it is arranged a color gradation with different lightness (value) in ascending or descending order, it changes the height of the centroid of a building. If brighty colors are located on the bottom of a facade, "it is easy to notice a sense of imbalance in the buildings of the street, and an anti-constructive consistency of the masses in the lower level" ${ }^{42}$. Bottoni relates the weight of the colors with Leonardo da Vinci's aereal perspective ${ }^{\dagger \dagger t}$, as it responds to same principles: "In general, the warm colors (red, orange) and earthy colors at their maximum intensity, give a sense of mass-volume-color, higher than the one given by some cold colors (like green, or blue) and even light violet [...]. A red, black or earthy Siena material resists better and is heavier than a light blue, gray, green olive, etc" ${ }^{43}$. Dr Nicholas Humphrey satblishes a "statistically significant order of apparent weight which, reading from heavy to light, is as follows: red, blue, purple, orange, green, and yellow. However, the influence of color on heaviness as judged by actual lifting seems slight, if at all significant" 44 .

In the industrial building for Stralsund shipyard (figs. 18), (F. E. von Garnier, Germany, 1999) the blues of the front facade reduce the visual weight of an architectural volume with huge dimensions in relation with the scale of the town where it is located. Although it also operates a strategy of mimicry into the sky (see chap. 4.2.1.), blue shades themselves make such an impressive mass to be less heavy, and even more when considering how it would look with reddish hues (Fig. 19).

\section{5. Color interfers in the texture of architecture}

Color arrangement may suggest a different texture of the building material. This is a cheap resource, which was commonly used in the past to emulate finest materials. It falls into disuse from A. Loos manifesto Ornament and Crime (1906), in which Loos claims for material truth. One of the consequences is the waiver, more or less consciously, to the color gradations in favor of the flat colors in later modern architecture. In fact, examples of contemporary buildings with colors imitating materials are very scarce. One of these is the IADE Totovola Building (Lisbon, 1973-1984) by the Portuguese architect Tomás Taveira (fig. 20), in which the concrete is painted with a metallic color to mimic the steel, because of very exceptional circumstances that occurred during the execution of the building. 
However, the expressionist painter V. Kandinsky points out that flat colors have inherent tactile qualities, something related to their synesthetic ability: "Some colors look rough and bristly, and others polished and velvety, and invite the caress (like the dark ultramarine blue, the green oxide chromium or the Garanza varnish). There are colors that look soft (the Garanza varnish) and others that seem so hard (the cobalt green or the blue-green rust) that, as early as they come out of the tube, seem dry" 45 . During the development of our research, we have found no contemporary buildings where it has consciously been raised this link between flat color and its intrinsic texture. However, there is an interest in performing colors with new textures incorporated. This is evidenced by Dutch architect $\mathrm{R}$. Koolhaas when he asks the more than thirty members of OMA to choose their favorite color ${ }^{\ddagger \ddagger \ddagger}$, proving that "only ten people chose a simple single colour. Most imagined their colours as a treatment, a way to affect reality in a more subtle way than mere paint: not simply a layer of colour but a more subtle conditioning, a layer that alters the state of the painted wall or object, a colour that would interfere with the status of the painted object " ${ }^{46}$. In these experiments with novel textures incorporated in the colored material, it highlights Swiss architecture (eg. Caixa-Forum Building, Herzog \& de Meuron, Madrid, 2008) (fig. 21). Also A. Bony's color designs for Jean Nouvel's architecture, in which he uses different kind of deterioration techniques to alter the walls' color and texture.

Although many contemporary buildings have a finishing texture which does not match with the genuine of the construction material, it is usually based on a geometric pattern, and not a naturalistic imitation of other construction materials. In this sense, we assess that contemporary color remains committed to the Loosian principle of not simulating another material ${ }^{47}$.

In the evaluation of color and texture, it is important to attend the cesia of the materials. Architect J. L. Caivano describes this term as "the modes of appearance produced by different spatial distributions of light" and can be defined by three variables: "perceived permeability (or its opposite, opacity), perceived darkness (or its opposite, lightness), and perceived diffusivity (or its opposite, regularity)" ${ }^{48}$.
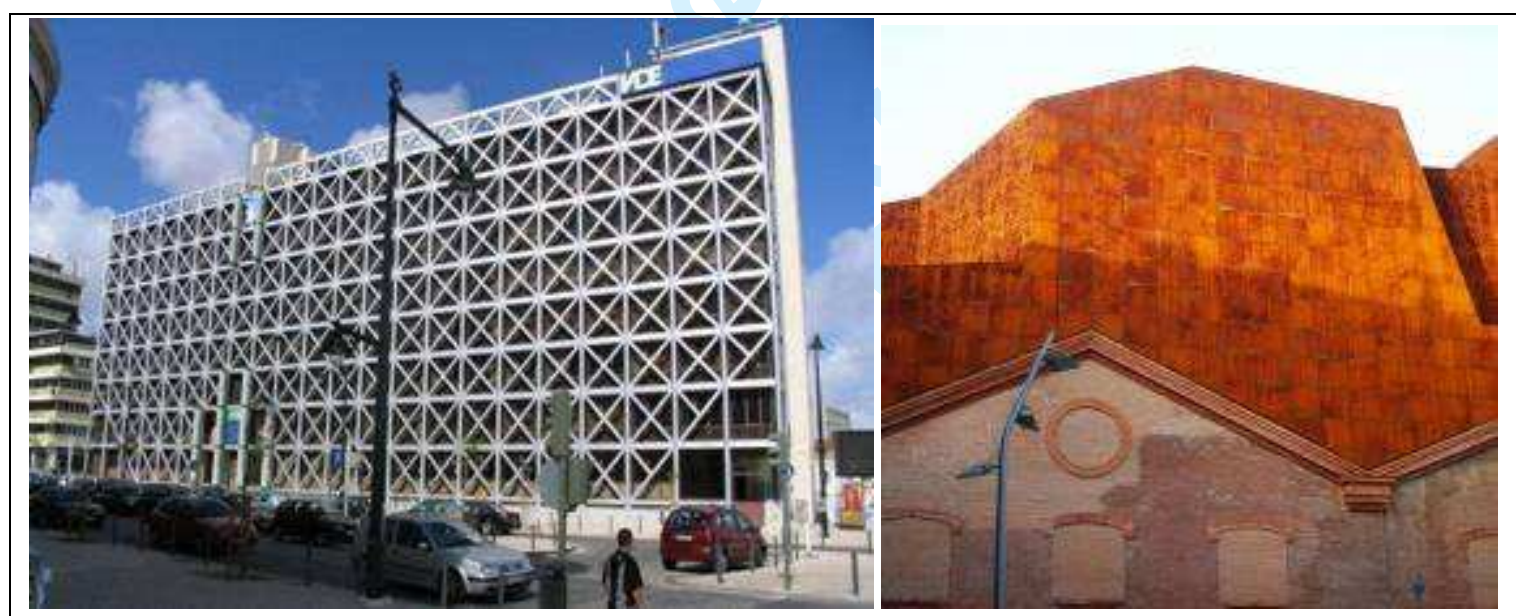

Fig. 20. Totovola Building (IADE), Tomás Taveira, Lisbon (Portugal), 1973-1984

Fig. 21. Caixa-Forum Building, Herzog \& de Meuron, Madrid, 2008. Photo in Public Gallery IMAR, Author Miguel de Guzmán, http://blog.bellostes.com/?s=herzog+y+de+meuron

\section{ESTRATEGY II: COLOR DESCRIBES THE BUILDING}

\section{1. Justification of the subcategories}

Every color composition that describes architecture in any aspect of its arrangement belongs to this section. Color is used in order to interfere with the reading of the building, its

¥¥¥ R. Koolhaas does so in 2001, when the British painting enterpraise Sikkens involves him in the project "New colours for a new century". 
comprehension. Color evidences those characteristics of the building which are not immediate a priori and require a process of interpretation by the observer. The colors that describe the architecture are coded colors, able to formulate and understand a message, which is usually related to the composition of shapes (chapter. 5.2), or the function of the building (chapter 5.3). The narrative sense of these colors helps to get one's bearings, or to understand the architectural object/ space in any of its peculiarities. These color arrangements are common in industry, where safety measures and efficient use of the facilities require color codes.

If we look at its historical development, descriptive color begins to acquire importance in the civil architecture in the $19^{\text {th }}$ century. "Under the pressure of dogmatic Ruskianian look of what constituted bad taste, the Victorian architecture tour in polychrome has survived little. Instead, the resurrection of the colors of antiquity emerged as an embellishment of the metals of the age of the machine, applying a striking color layer for protecting steel structures such as bridges, vehicles and engines, including parts of the industrial and agricultural machinery" ${ }^{49}$.

If we pay attention to the color resources chosen to describe the buildings, we see that color schemes tend to be easy to differentiate and able to associate with a more or less conventional meaning. The designer has to be expert in the chromatic discrimination variables, the thresholds at which they occur and the laws of contrast. The discrimination threshold for a given parameter of color (hue, value or chroma) is the minimum relative difference required for two colors which are different in physical measurements, to be perceived unequal under specific lighting conditions. Although we should not forget that, to differentiate two objects, "shape is a better identification and orientation media than color, unless color discrimination is reduced to the primary ones" 50 .

\section{2. Color describes architectural shape}

When color is used as a strategy to describe the architectural shape, it communicates some aspects of the metric (1), the structural system (2) or the logic of formal operations used in the design (3), among others. The Spanish architects Anna and Ricardo Bofill define this color color strategy when assure that color "should be used to underline the internal laws of the architectonic form of the building and to make it visible and artistic" ${ }^{51}$.

(1) When describing the metric of the building color informs of the size and the proportional relationships between the different parts. Le Corbusier used this strategy in the Pilgrim House in Notre Dame du Haut (Ronchamp, France, 1950-1955) (fig. 22), with a sequence of triangles with different colors over the facade, which show the proportions that justify the dimensions. In Heidi Weber Pavilion (Zurich, 1965) (fig. 23), color identifies the rectangular building module, which consists of the repetition of precast pieces with a $2 \times 1$ proportion.

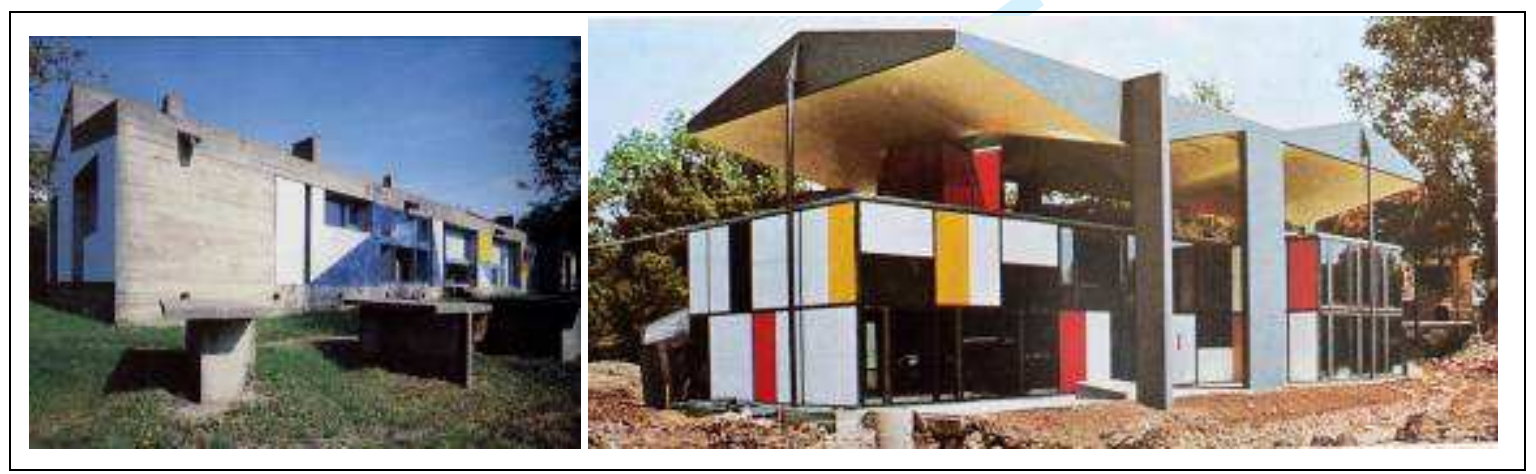



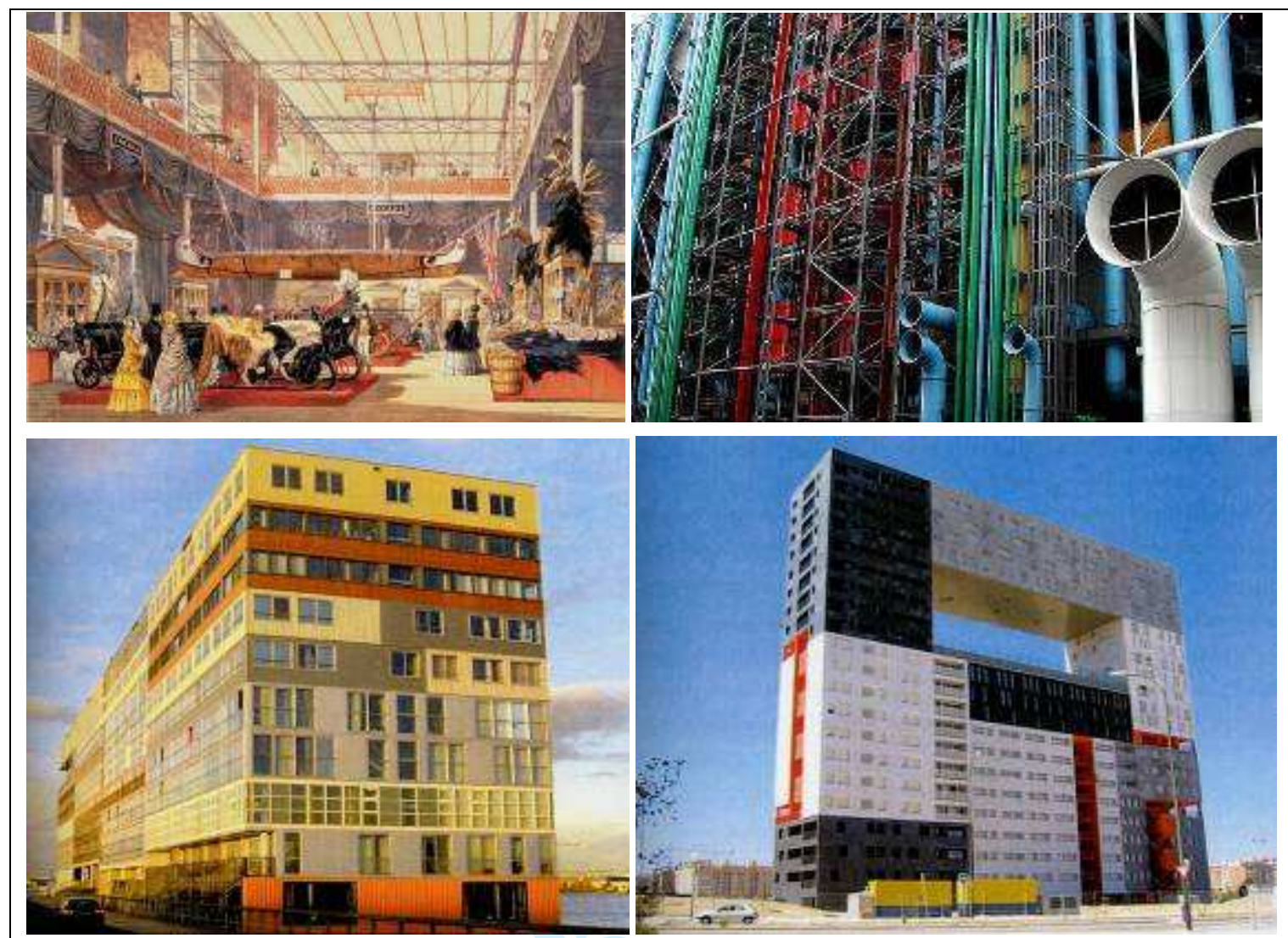

Fig. 22. Maison des Pèlerins, Le Corbusier, Ronchamp, France, 1950-55.

Fig. 23. Heidi Weber Pavilion, Le Corbusier, Zurich, 1965. In:

Fig. 24. Crystal Palace, Joseph Paxton, London International Exhinition, 1851.

In http://carefullyaimeddarts.files.wordpress.com/

Fig. 25. George Pompidou Arts Centre, Richard Rogers and Renzo Piano, Paris, 1971-1977.

Fig. 26. Silodam Building, MVRDV architects, Borneo, Amsterdam, 2002. Courtesy MVRDV architects

$<$ http://www.mvrdv.nl/>

Fig. 27. Mirador Building. MVRDVarchitects, Madrid, 2004. Courtesy MVRDV architects http://www.mvrdv.nl/

(2) When color describes the structural system of architecture, it tells us about its supporting method. A pre-modern example is the Crystal Palace by Joseph Paxton (1803-1865) for the International Exhibition (London, 1851), and colored by architect Owen Jones (18091874). This building is the paradigm of the enlightened society which is confident of the progress of reason and science, and thus organizes the color in a scientific way. "Jones deployed these hues [blue, yellow and red] to visually underline its structural form -composed of steel, cast iron and wood- following the chromatic laws of M.E. Chevreul, the French scientist and authority on color who, still living at that time, had his Cercle Chromatique exhibited in the French Court section of the Great Exhibition in Hyde Park" ${ }^{52}$ (fig. 24). These color arrangements that describe the structural system, preveal during modern period thanks to the interest of architects in machine functionalism (eg. Le Corbusier), and is inherited by utopian trends during the sixties till nowadays. The group of British architects Archigram revitalized the interest in industrial machinery as an emblem of a technological world which was to come. If Le Corbusier was interested in the "machine for living", Archigram is just interested in the appearance of that machine. The Arts Centre George Pompidou (Richard Rogers and Renzo Piano, Paris, 1971-1977) (fig. 25) crystallizes this technological admiration and anticipates later High Tech architecture. This is the case of contemporary architects such as Norman Foster and Richard Rogers, who use color to express the structural system and introduce color accents in their buildings.

(3) When the color describes the formal operations carried out during the building design, it expresses the process and explains composition mechanisms such as the union, subtraction, juxtaposition or hierarchy established between the components. Such is the case of the residential building Silodam (MVRDV, Amsterdam, 2002) (fig. 26), where the color explains that the final volume of the building is the result of stacking up a serie of simple prisms, like if it was a large container ship. The color of each piece also identifies different typologies of houses, 
offices, etc. This strategy is also developed in the residential building Mirador (MVRDV, Madrid, 2004) (fig. 27). If architects had resorted to monochromy, this building would have been understood as a large rectangular prism with a big hole, and not as a collection of smaller parts that result in a bigger shape.

\section{3. Color describes architectural function}

Modern architecture emancipated from the hierarchical composition systems of classicism, and expressed a new freedom by different formal devices. One of these devices is the geometric pattern, an undifferentiated sequence, homogeneous and isotropic which arises as a logical consequence of prefabrication, and expresses the spirit of universality and democracy that underlies the modern movement. Often, in modular buildings, especially for public use, architects arrange color as a visual code that describes the function and allows users to orient themselves quickly. The Bauhaus building itself (W. Gropius, Dessau, 1926) was susceptible to a functional color scheme, proposed by architect Hinnerk Scheper.

Sir Norman Foster assures, in relation to Commerzbank (Frankfurt, 1997), that "by colour-coding the circulation cores in Per's [Per Arnoldi's] signature primaries of red, yellow, and blue, we were able to make the experience of navigating the building simple and pleasurable. [...] So you are guided from the lobby to your office by the simple experience of following your designated colour" 53 .

There are many outstanding examples of functional color compositions, such as the Terminal 5 at Barajas Airport (R. Rogers and Lamela, Madrid, 2005) (fig. 28), where color allows to recognize the gate to go to, and visually estimate the distance that lasts. Another example is the chromatic intervention in Overschiesestraat (Florentijn Hofman, Schiedam, Netherlands, 2003) (fig. 29) where the historic urban center is revitalized by coloring in yellow the pavement of the main streets that come inside it.

Other times, colors are used with conventional meanings, mostly recognized by any observer in that specific context. This occurs in the Reichstag in Berlin (N. Foster, 1999), where "green meant the Greens, black ment the Fascists, red the Reds (not love at all) and blue the Conservatives" 54 . Color can describe the existence of a corporation (eg. the yellow Renault Centre, N. Foster, Swindon, England, 1982) (fig. 30), a municipal service (eg. red and green in a fire station and police, Sauerbruch \& Hutton, Berlin, 1999/2004), etc. Color can indicate the operation of building facilities, differentiating the pipes for supplies, emergency systems, etc (eg Arts Center George Pompidou, Richard Rogers and Renzo Piano, Paris, 1971-1977) (fig. 25), something usual in industrial architecture (eg. The Solmer Steeel Plant, Jean Philippe Lenclos, Fos sur Mer, France) (fig. 31). Color can even distinguish between "public spaces, gardens and semi-private spaces" (eg. Kirchsteigfeld Potsdam, Werner Spillmann, Germany, 1997) ${ }^{55}$. Color can represent the activities that take place inside the building, although not necessarily in a figurative manner. Some of these cases are discussed later (chap. 6), as these color compositions are considered to be mainly arranged by their intrinsic plastic value.

It should be emphasized the importance of the context to interpret the conventional meaning of color. As Dirk Meyhofer states, after selecting nearly seventy contemporary colored buildings in Europe, "color does not mean the same thing in every context, rather [...] a particular color may convey a different meaning depending on the case to which it is assigned" 56. Psychologist Nicholas Humphrey deduces something similar from natural world: "The flushed cheeks of a man or woman may indicate anger, but they may equally indicate pleasure [...] The content of the message can be interpreted only when the context of the redness is defined" 57 . 

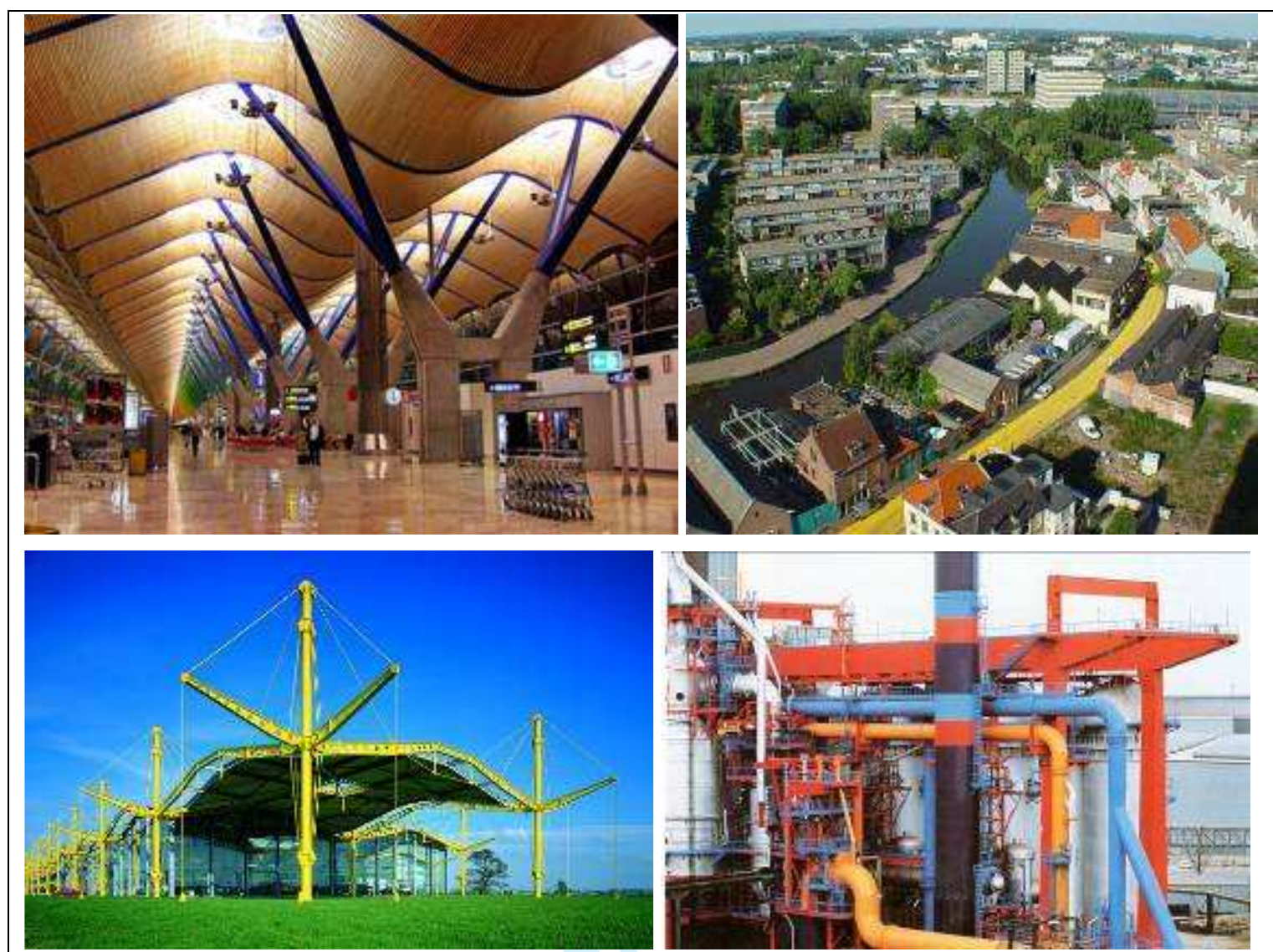

Fig. 28. Terminal T5 at Barajas Airport, Richard Rogers Partnership, Madrid, 2005.

Fig. 29. Yellow Street (Overschiesestraat), Florentijn Hofman, Schiedam, Netherland; 2003. In <http://www.florentijnhofman.nl/>

Fig. 30. Renault Centre, N. Foster, Swindon, England, 1982. In <http://www.fosterandpartners.com/>

Fig. 31. Solmer Steelworks, Jean Philipe Lenclos, Fos Sur Mer, Marseille (France). In: Linton H. Color in Architecture : Design Methods for Buildings, Interiors, and Urban Spaces. New York \& London: Ed. McGraw-Hill, 1999. pp 267.

\section{ESTRATEGY III: COLOR IS ARRANGED FOR ITS INTRINSIC VALUE}

Color for its intrinsic value mainly aims to beautify architecture. Its arrangement has no more connections with other physical or functional properties of building but its inherent aesthetic appeal. Spanish architects Anna and Ricardo Bofill accurately describe the possibility to use color for its intrinsic value when they assure that "through color, architecture can be brought to life, a living breath to animate the coldness of the building" ${ }^{58}$. Foster's color consultant Per Arnoldi says something similar, as he believes "that without prior assumptions, without training, with no knowdlege of codes, we can feel wether a colour in a context [...] has been added and incorporated beneficially. Because somebody wishes you well" ${ }^{59}$.

Color introduces alien benefits into the building itself, and these come about thanks to the plastic possibilities of color. This occurs when color is introduced as an outer layer, although not every example may be understood in terms of dimensionality or $\mathrm{skin}^{60}$.

This is the case of British architect William Alsop, who arranges color exclusively for its intrinsic value, denying any rational argument in relation with the results (eg. Colorium, Dusseldorf, Germany, 2001) (fig. 32): "Architecture critics criticize me for having colour at the moment they can not predict it. [...] They have lots of questions about why am I doing that... and I can not really answer why" ${ }^{61}$. We can say that these color compositions have a selfsupporting character and there is no discoursive effort to support them by compositional, structural or functional reasons. Color essentially pays attention to its own plastic criteria. 


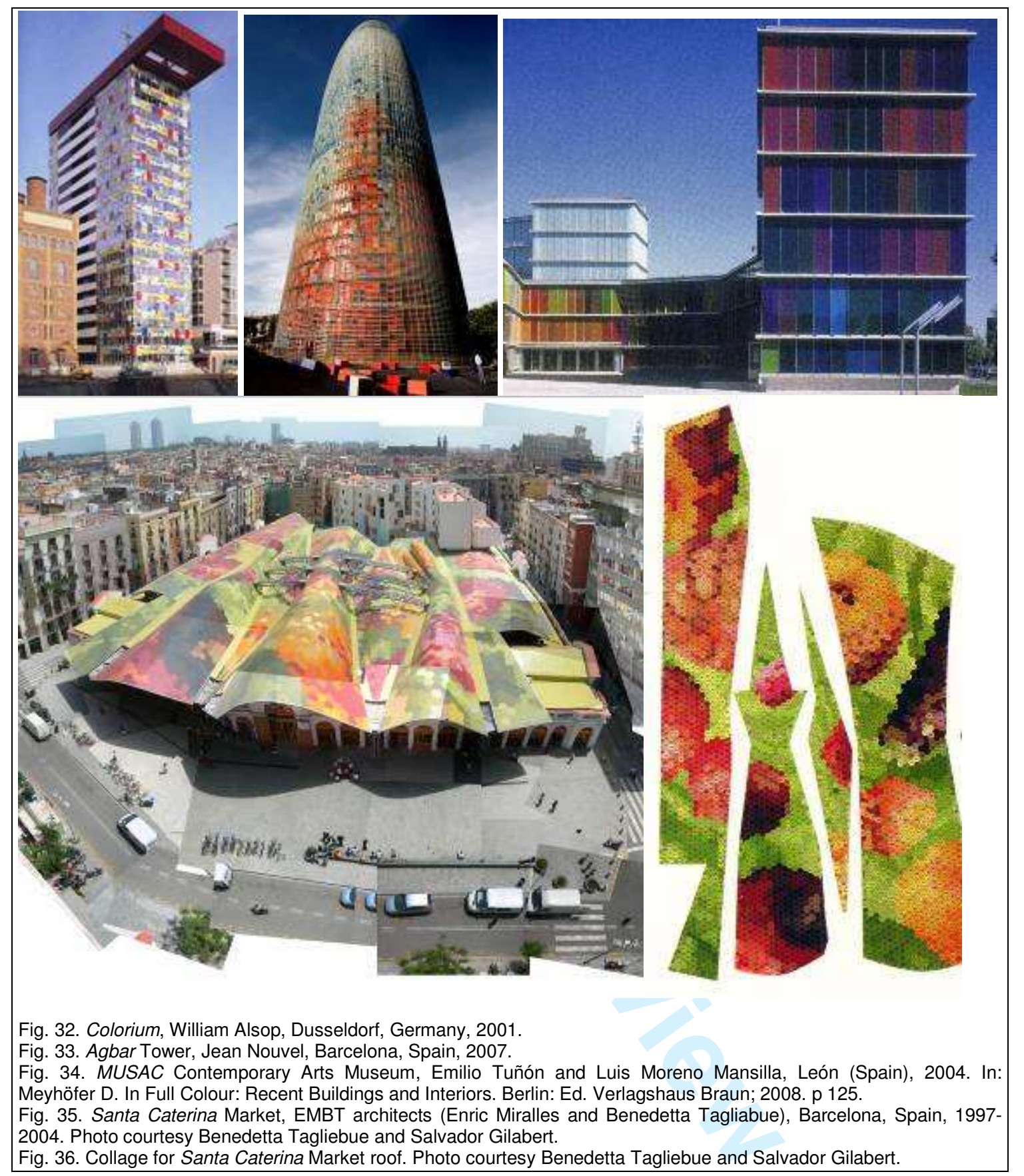

In these cases, if color arrangements are ever justified, it is usual to explain the references that were used during the design. These imaginative referents have made the creative work easy and have suggested certain color ranges, but are often difficult to track when the building is over. This happens in the Agbar Tower (Jean Nouvel, Barcelona, Spain, 2007) (fig. 33) whith a shape and colorr that remind a flame. This symbolic suggestion, not necessarily shared by architect and observer, does not add, nor substract, plastic value to a composition based on aesthetic criteria. Something similar happens with the outer color arrangement in the Museum of Contemporary Art in Leon (Emilio Tuñón and Luis Moreno Mansilla, Spain, 2005) (figs. 34) which are refered to the stained-glass windows of the Gothic cathedral of the city, but with no relation with other compositional or functional features of the building.

In Santa Caterina Market (EMBT, Barcelona, Spain, 1997-2004) (figs. 35, 36), the colors of the roof reproduce the image of a fruit stall on a large scale and are superimposed onto the real market sales stalls. The building is understood as a palimpsest, which shows the accumulation of the various historical facts as strata. The substrate corresponding to the contemporaneousness is the roof, which virtually performs the chromatic experiences that take place underneath, a kind of transparency or tele-reality. This is an interesting experience for 
contemporary perception, which blurs the boundaries between reality and fiction ${ }^{62}$. Other example is the Pharmaceutical Research Laboratories in Biberach (Sauerbruch \& Hutton, Germany, 2000-2002), where colored facades reproduce the microscopic structure of one of the drugs that are synthesized in the interior. In both cases color correspond to figurative references, but its excessive abstraction prevents the reading of any meaning by the observer. Color can only be evaluated by its intrinsic beauty, as it would be done by the discipline of painting. In these buildings, architects deal with the equilibrium of the color composition itself: distribution of the dealing colors, contrasts, rhythm, etc.

\section{CONCLUSIONS}

We have deduced, justified and described three groups of plastic strategies that color enables as it is a plastic medium for architecture: color interfers with the perception of the visual properties of architectural shapes (I), color describes the building (II) and color is arranged for its intrinsic value (III).

It should be emphasized that these strategies are not mutually exclusive but complementary and, in fact, the most interesting color compositions are those that successfully reconcile all of them. By way of example and conclusion we describe the simultaneous use of these three strategies in the extension of a pre-existing building to serve as a fire and police station (Sauerbruch \& Hutton, Berlin, 1999/2004). Color links building and environment: red besides the ancient face brick facade and green besides a nearby grove (strategy I). Moreover, color describes the functions of the building, as red and green are the corporative colors that identify German fire department and police corp, respectively, so a user may easily recognize what part are located each of the functions (strategy II). Finally, and regardless other circumstances, new facade has a plastic self-interest, by providing a balanced gradation between red and green (strategy III). In short, color is usefull as a strategy to easily solve various needs of the architecture.

We insist that these color strategies do not aim to cover the whole complexity of color composition in architecture. Color should never be reduced to just a sintatic understanding, as it is a much more totalizing and inherently significant matter. We definitely believe that our color classification system proposed is necessary to provide a rational order to analyse, understand and create colored architecture, but it is not enough if not linked with other ethic and aesthetic significants which we have consciously left aside.

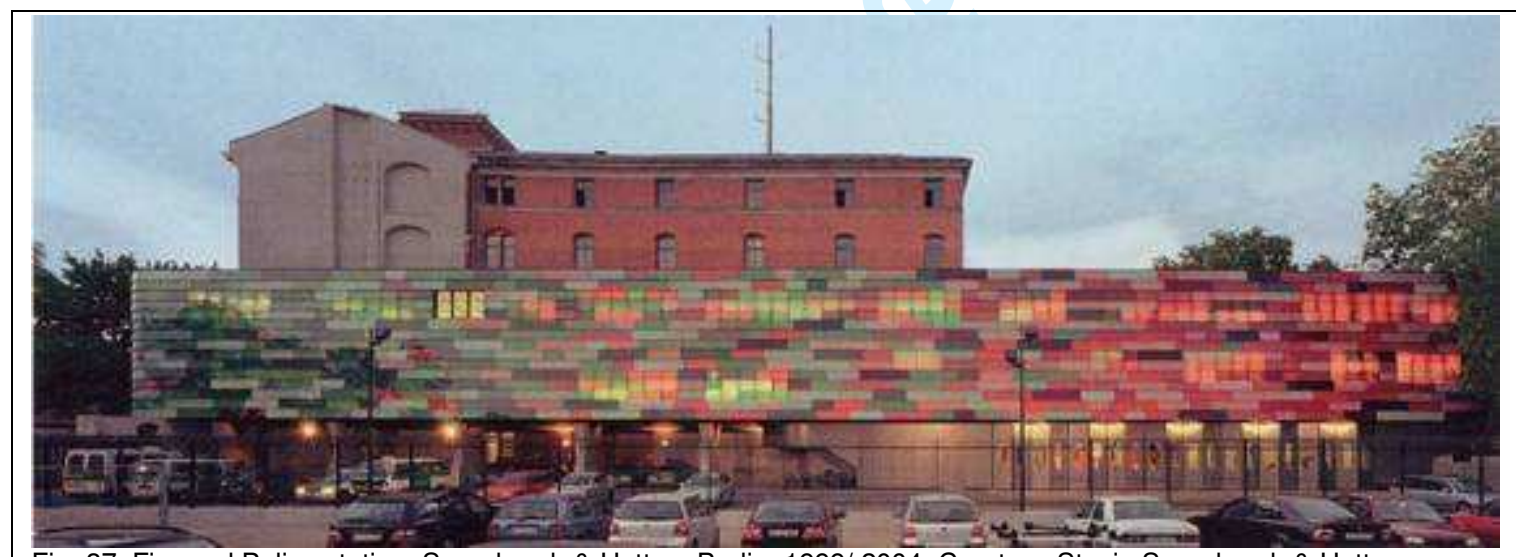

Fig. 37. Fire and Police station, Sauerbruch \& Hutton, Berlin, 1999/ 2004. Courtesy Stucio Sauerbruch \& Hutton <http://www.sauerbruchhutton.de/> 


\section{REFERENCES}

1. Arnoldi P. Colour is communication: Selected projects for Foster+Partners 1996-2006. Basel: Birkhäuser: 2007. p 7.

2. Lancaster M. Colourscape. London: Academy Editions; 1996. p 88.

3. Green-Armytage P. Seven kinds of colour. In: Porter T and Mikellides B, editors. Colour for architecture today. London: Taylor \& Francis; 2009. p 64-68.

4. Fridell Anter K. Painted walls: From pictures and imitations to coloured space. School of architecture, KTH. Stockholm: International Color Association; 2004. p 227.

5. Arrarte Grau M. On the bonding of colour and architecture: Colouring modes. Stockholm: International Colour Association. Interim Meeting "Colour affects \& effects"; 2008. p 54.

6. Schindler VM. Colour culture in European architecture and Le Corbusier: On different approaches to applying colour in architecture. Buenos Aires: Proceedings of the AIC congress "Color: ciencias, artes, proyecto y enseñanza"; 2004. p 393-401.

7. Serra J. Color y espacio, teoría y práctica. Reflexiones con Mark Wigley y Mattias Sauerbruch. Valencia: EGA. Revista de Expresión Gráfica Arquitectónica; 2011.

8. Le Corbusier. Modulor 2: 1955 (los usuarios tienen la palabra) continuacion de "El modulor, 1984". Buenos Aires: Poseidón; 1962. p 239. Trans. by author

9. Marina JA. Teoría de la inteligencia creadora. Barcelona: Anagrama; 2000. pp 384.

10. Dondis DA. La sintaxis de la imagen: Introducción al alfabeto visual. Barcelona etc.: Gustavo Gili; 1980. pp 210. Trans. by author.

11. Arnheim R. Arte y percepción visual. Psicología del ojo creador. Madrid: Alianza; 1981. pp 553.

12. Ching FDK. Arquitectura: Forma, espacio y orden. Mexico: Gustavo Gili; 1982. p 397. Trans. by author.

13. Le Corbusier and Rüegg A. Polychromie architecturale: Le corbusier farbenklaviaturen von 1931 aund 1950= Le corbusier's color keyboards from 1931 and 1959= Les claviers de couleurs de le corbusier de 1931 et de 1959. Basel: Birkhäuser; 1997. p121.

14. Wigley $M$. White walls, designer dresses: The fashioning of modern architecture. Cambridge: MIT Press; 1995. p 121.

15. Montaner JM. Sistemas arquitectónicos contemporáneos. Barcelona: Gustavo Gili; 2008. pp 223.

16. MVRDV. Projects realized. <http://www.mvrdv.nl/\#/news/074studiothonik>

17. Gage J. Color y cultura: La práctica y el significado del color de la antigüedad a la abstracción. Madrid: Siruela; 1997. pp 335.

18. García Codoñer A., Llopis Verdú J., Torres Barchino A. and Serra Lluch J. El color como factor diferencial en la ciudad histórica del arco mediterráneo. Madrid: Congreso europeo sobre investigación arquitectónica y urbana, Escuela Técnica Superior de Arquitectura, Universidad Politécnica de Madrid (ETSAM/UPM); 2007.

19. Hadid Z. Zaha hadid, 1996-2001: Landscape as a plan= el paisaje como planta. Madrid: El Croquis; 2001. p 28-39.

20. Betsky A. Pleasurable and essential: Colour and content in the work of Sauerbruch \& Hutton. Madrid: El Croquis 114(1): 6; 2003. p 8.

21. Smedal G. The longyearbayen project: Approach and method. In: Porter T and Mikellides B, editors. Colour for architecture today. London: Taylor \& Francis; 2009. p 75.

22. Ibid Dondis DA. 1980. p 48. Trans. by author.

23. Serra J. La monocromía como recurso plástico para la arquitectura. Estudio de tres casas azules. Proceedings of the "IX National Congres od Color", Universidad de Alicante. Alicante: Sociedad Española de Óptica, 2010. p 152-156.

24. Ibid Le Corbusier and Rüegg A. 1997. p 27.

25. Ibid Le Corbusier and Rüegg A. 1997. p121.

26. Tornquist J. Color y luz: Teoría y práctica. Barcelona: Gustavo Gili, 2008.

27. Swirnoff L. Dimensional color, 2nd ed. New York; London: W. W. Norton; 2003. p 67.

28. Hayten PJ. El color en arquitectura y decoración. Barcelona: LEDA Las Ediciones De Arte; 1960. p 22. Trans. by author.

29. Swirnoff L. Color structure: A perceptual techtonic. In: Porter T and Mikellides B, editors. Colour for architecture today. London: Taylor \& Francis, 2009. p 82.

30. Hard A. In: Lancaster M. Colourscape. London: Academy Editions, 1996. p 30. 
31. Ibid Le Corbusier and Rüegg A. 1997. p 114-115.

32. Ibid Le Corbusier and Rüegg A. 1997. p 116-117.

33. Mahnke FH. Color, environment, and human response: An interdisciplinary understanding of color and its use as a beneficial element in the design of the architectural environment. New York; London: Van Nostrand Reinhold; Chapman \& Hall distributor, 1996. p 72.

34. Prak NL. The visual perception of the built environment. Delft: Delft University Press; 1977. p. 33

35. Ittelson WH and KilpatricK FP. Experiments in percepcion. Science American 185:50-5; 1952.

36. Miller MC. Color for interior architecture. Chichester: John Wiley \& Sons; 1997.

37. Prak NL. 1977. The visual perception of the built environment. Delft: Delft University Press. p. 33

38. Faulkner W. Architecture and color. New York: Wiley-Interscience; 1972.

39. Ibid Hayten PJ. 1960. p 22-23.

40. ibid Mahnke FH. 1996. p 72.

41. Ibid Le Corbusier and Ruegg A. 1997. p 115.

42. Bottoni P. Cromatismi architettonici. Architettura e Artti Decorative 1927; VI( 1-2).

43. Ibid Bottoni P. 1927.

44. Humphrey N. The effect of colour on our perception of space. In: Porter T and Mikellides B, editors. London: Studio Vista; 1976. p 98.

45. Kandinsky V. De lo espiritual en el arte, $3^{\text {rd }}$ ed. Barcelona: Labor; 1992. p 43-44. Trans. by author.

46. Koolhaas R. The future of colours is looking bright. OMA 30 colours. Koolhaas R, Foster N, Mack G. and others, editors. In: Colours. Basel etc.: Birkhäuser; 2001. p 12.

47. Serra J, Llopis J. and García A. Ruskin revisited: Material truth in modern and contemporary architecture. In: Zenaro $\mathrm{P}$, editor. Proceedings of the international Conference: Colour and light in Architecture. Venice: Università luav di Venezia, Faculty of Architecture, 2010. p 439-444.

48. Caivano JL, Menghi I. and ladisernia N. Cesia and paints: An atlas of cesia with painted samples. Proceedings of the AIC 2004 Color and Paints, Interim Meeting of the International Color Association. $113 \mathrm{p}$.

49. Brino G. Italian colour plans (1978-2007). In: Porter T and Mikellides B, editors. Colour for architecture today. London: Taylor \& Francis, 2009. p 30-35.

50. Arnheim R. El poder del centro: Estudio sobre la composicion en las artes visuales. Madrid: Alianza; 1984. p 239.

51. Bofill A and Bofill R. In: Porter T and Mikellides B, editors. Colour for architecture. London: Studio Vista; 1976. p 49.

52. Ibid Brino G. 2009. p 35.

53. Ibid Arnoldi P. 2007. p 7-8.

54. Ibid Arnoldi P. 2007. p 13.

55. Spillmann W. Unity in diversity at kirchsteigfeld, postdam. In: Porter T and Mikellides B, editors. Colour for architecture today. London: Taylor \& Francis; 2009. p 36.

56. Meyhöfer D. In full colour: Recent buildings and interiors. Hinc A, Hochrein J, Laswitz S. and others, editors. $1^{\text {st }}$ ed. Berlín: Verlagshaus Braun; 2008. p 7.

57. Humphrey N. The colour currency of nature. In: Porter T and Mikellides B, editors. London: Studio Vista; 1976. p 98.

58. Ibid Bofill A and Bofill R. 1976. p 49.

59. Ibid Arnoldi P. 2007. p 14.

60. Baraona Pohl E. Piel, Skin. Baraona Pohl E, editor; $1^{\text {st }}$ ed. España: Imaginación impresa; 2007.

61. Serra J. Colores que alumbran proyectos. Conversando con William Alsop. EGA, Revista De Expresión Gráfica Arquitectónica 1(15):16-25; 2010.

62. Serra J, Gilabert S, Torres A, Llopis J and García A. The colour of food: Last layer on the palimpsest of Sta. Caterina market in Barcelona. Mar de la Plata: Proceedings of the AIC 2010 interim meeting: Color and food, from the farm to the table; 2010. p 178-181. 


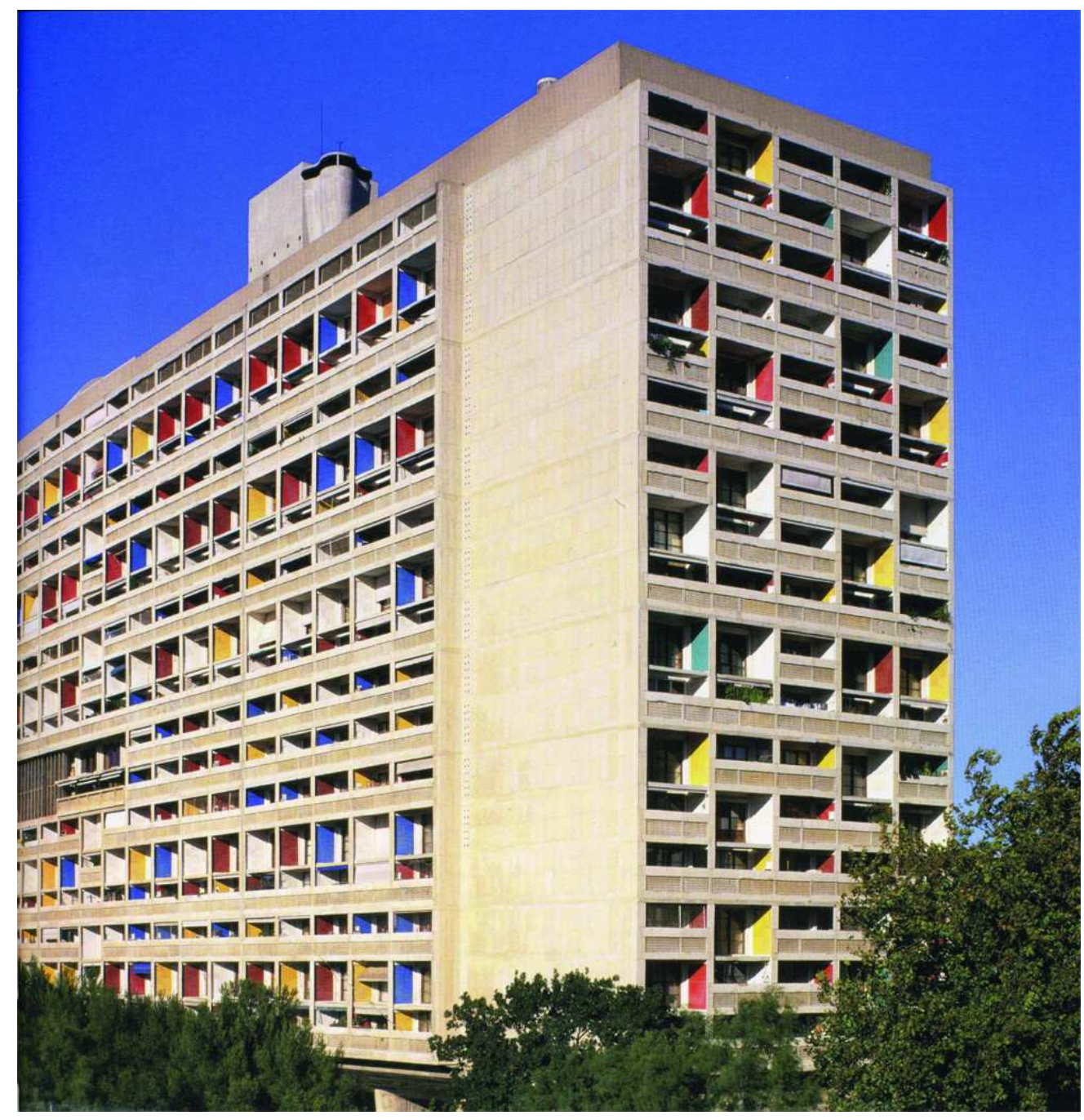

Fig 1. Unitè d'Habitation, Le Corbusier, Marseille, France, 1945-1952. In : Noury L. La couleur dans la ville. Thouard V, editor. 1st ed. Paris: Moniteur (Départment Architecture); 2008. p 43. $84 \times 87 \mathrm{~mm}(300 \times 300 \mathrm{DPI})$ 
Comparative among different color classification systems by authors

\begin{tabular}{|c|c|c|c|c|c|}
\hline \multicolumn{3}{|c|}{ J. Serra } & K. Fridell & M. Arrarte Grau & V. Schindler \\
\hline \multirow{6}{*}{$\begin{array}{l}\text { Estrategie I: } \\
\text { Color interfers } \\
\text { with the } \\
\text { perception of the } \\
\text { visual properties } \\
\text { of architectural } \\
\text { shapes }\end{array}$} & & $\begin{array}{l}\text { Mimicry/ } \\
\text { Singularity }\end{array}$ & \multirow{6}{*}{$\begin{array}{l}\text { Painting for illusion } \\
\text { Spatial use of colour }\end{array}$} & Neutralizing & \multirow{8}{*}{ Volumetric sense } \\
\hline & Geometry & $\begin{array}{l}\text { Integration/ } \\
\text { Disintegration }\end{array}$ & & Plannar/ volumetric & \\
\hline & & $\begin{array}{l}\text { Geometric } \\
\text { distortion }\end{array}$ & & & \\
\hline & Dimensions & & & & \\
\hline & $\begin{array}{l}\text { Visual } \\
\text { weight }\end{array}$ & & & & \\
\hline & Texture & & & & \\
\hline \multirow{2}{*}{$\begin{array}{l}\text { Estrategie II: } \\
\text { Color describes } \\
\text { the building }\end{array}$} & Functional & & Funtional coloring & \multirow{2}{*}{ Structural or syntax } & \\
\hline & Formal & & $\begin{array}{l}\text { Painting for allusion } \\
\text { Carrying codes }\end{array}$ & & \\
\hline \multirow[t]{2}{*}{$\begin{array}{l}\text { Estrategie III: } \\
\text { color is arranged } \\
\text { for its intrinsic } \\
\text { value }\end{array}$} & & & Painted decorations & Decorative & $\begin{array}{l}\text { Textil or decorative } \\
\text { sense }\end{array}$ \\
\hline & & & & $\begin{array}{l}\text { Color layer } \\
\text { White color }\end{array}$ & \\
\hline
\end{tabular}

Fig. 2. Table comparing the color classification systems used by different authors, with respect to the one adopted in our research. 


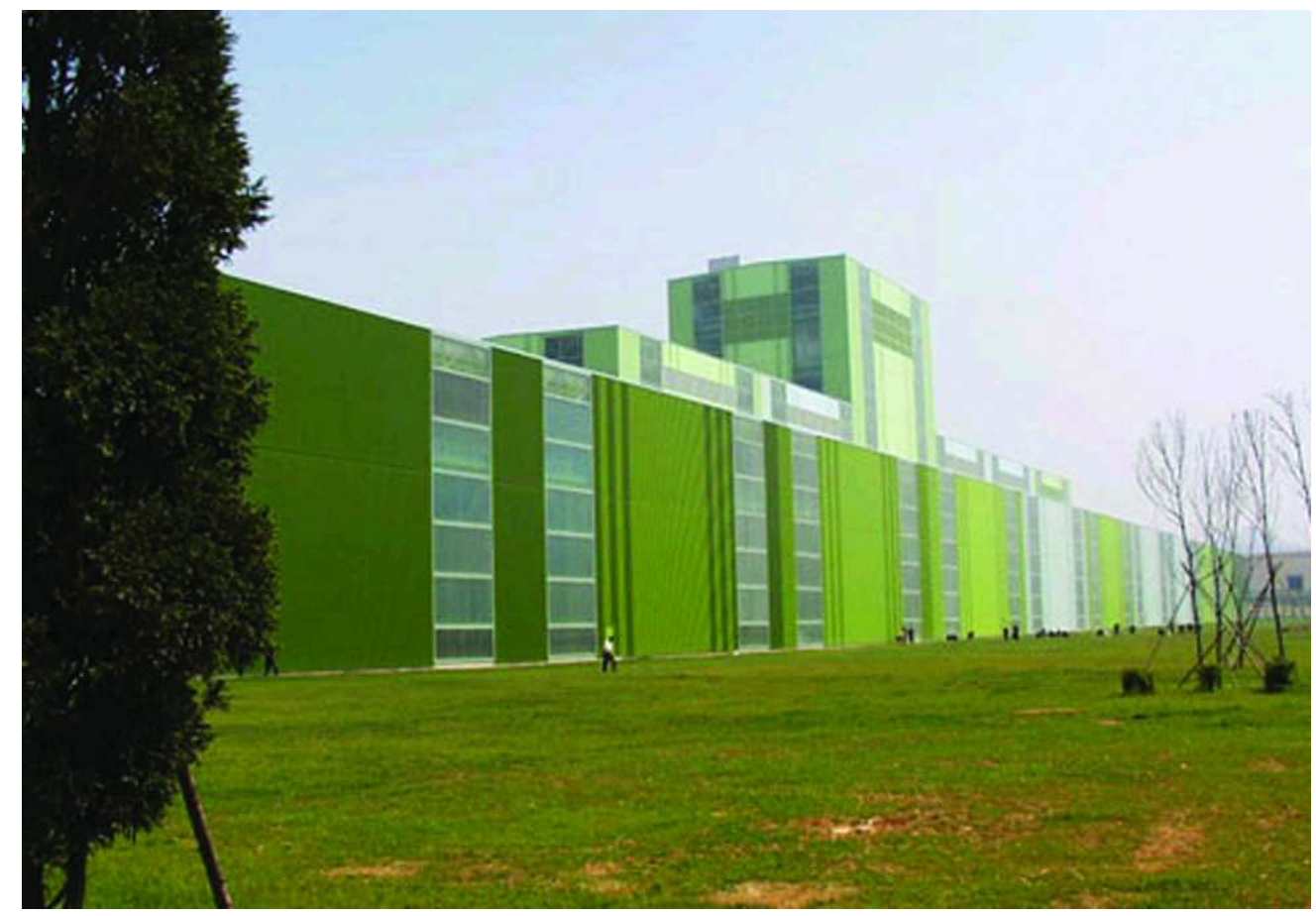

Fig. 3. ThyssenKrupp AG Feuerbeschichtungsanlage FBA 8. Friedrich Ernst von Garnier, Dortmund (Germany), 2003. Courtesy Stucio Ernst Von Garnier <http://www.studiovongarnier.de/> $41 \times 28 \mathrm{~mm}(600 \times 600 \mathrm{DPI})$ 


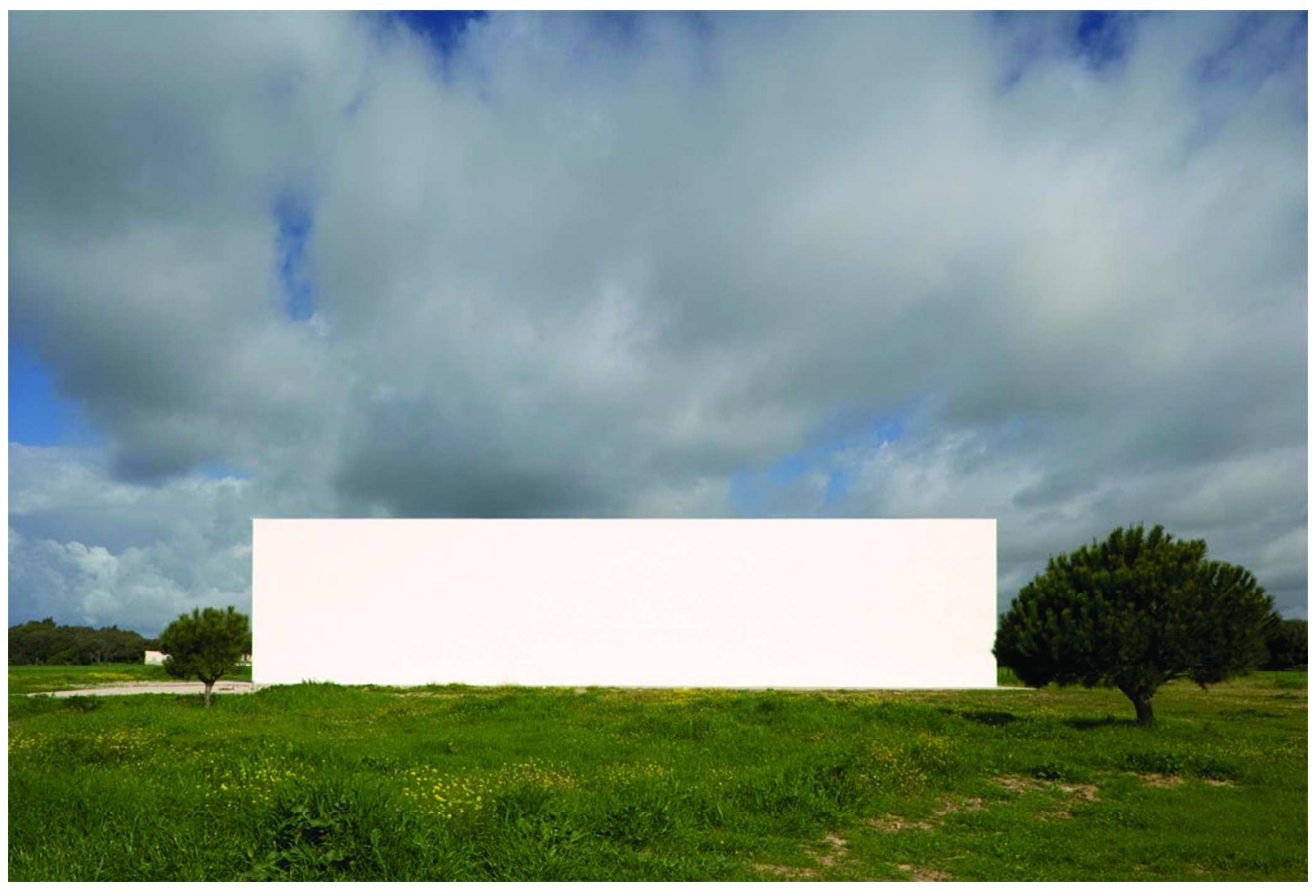

Fig. 4.Guerrero House. Alberto Campo Baeza, Zahora, Cádiz (España), 2005.

In: < http://arquitecturamashistoria.blogspot.com/2008/04/la-idea-construda-de-campo-baezaun.html>

$352 \times 236 \mathrm{~mm}(300 \times 300$ DPI $)$ 


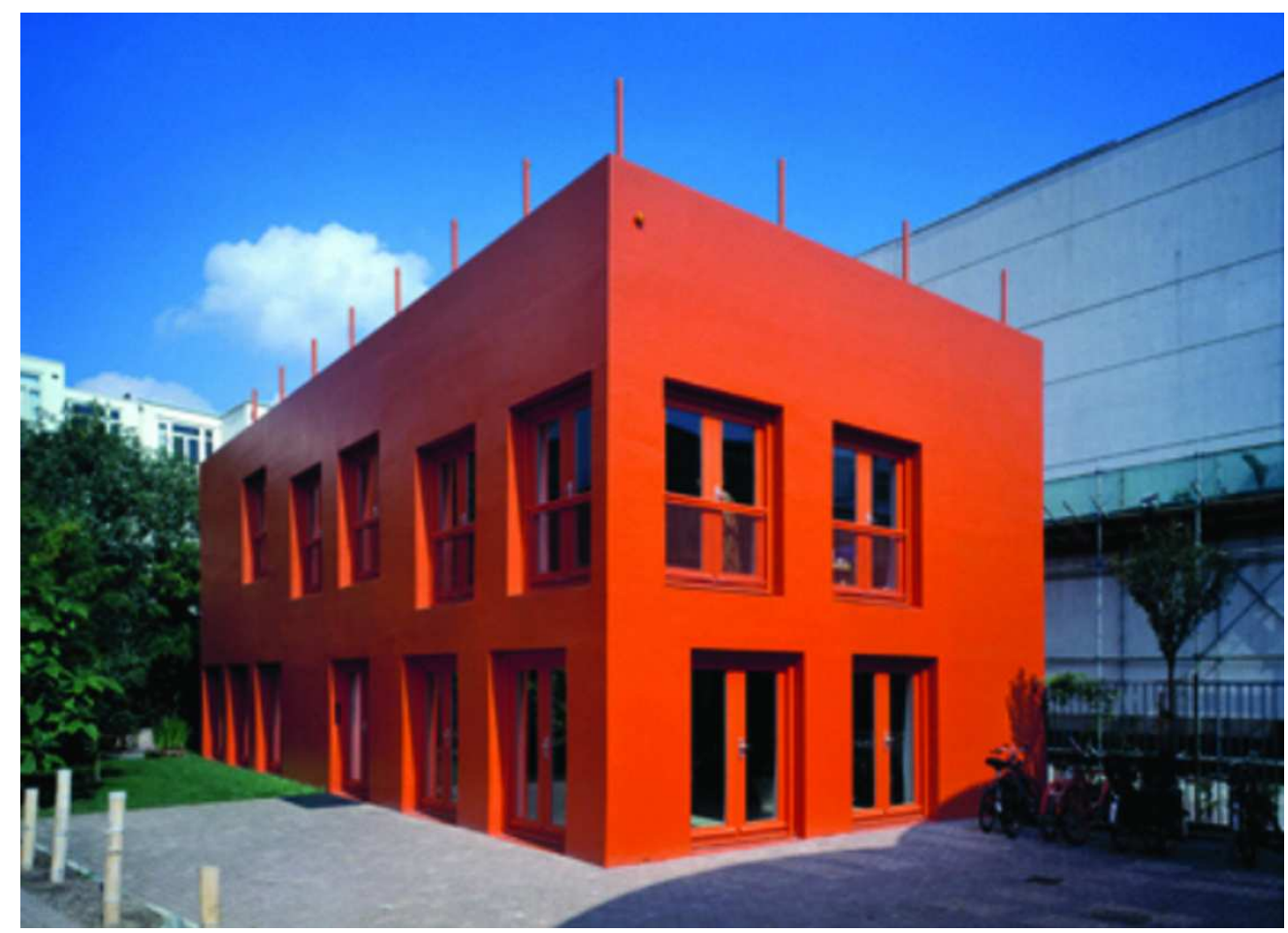

Fig. 5. Studio Thonik or the Orange House. MVRDV arquitects, Ámsterdam (Holanda), 1998-2001. Courtesy MVRDV architects <http://www.mvrdv.nl/> $48 \times 34 \mathrm{~mm}(600 \times 600 \mathrm{DPI})$ 
Fig. 6. Siedlungen Onkel Tom's Hutte. Argentinische Alleé, B. Taut, Zehlendorf (Germany), 19261931. In: Taut B. and Nerdinger W. Bruno Taut: 1880-1938. Milano: Electa, 2001. $84 \times 56 \mathrm{~mm}(300 \times 300$ DPI $)$ 


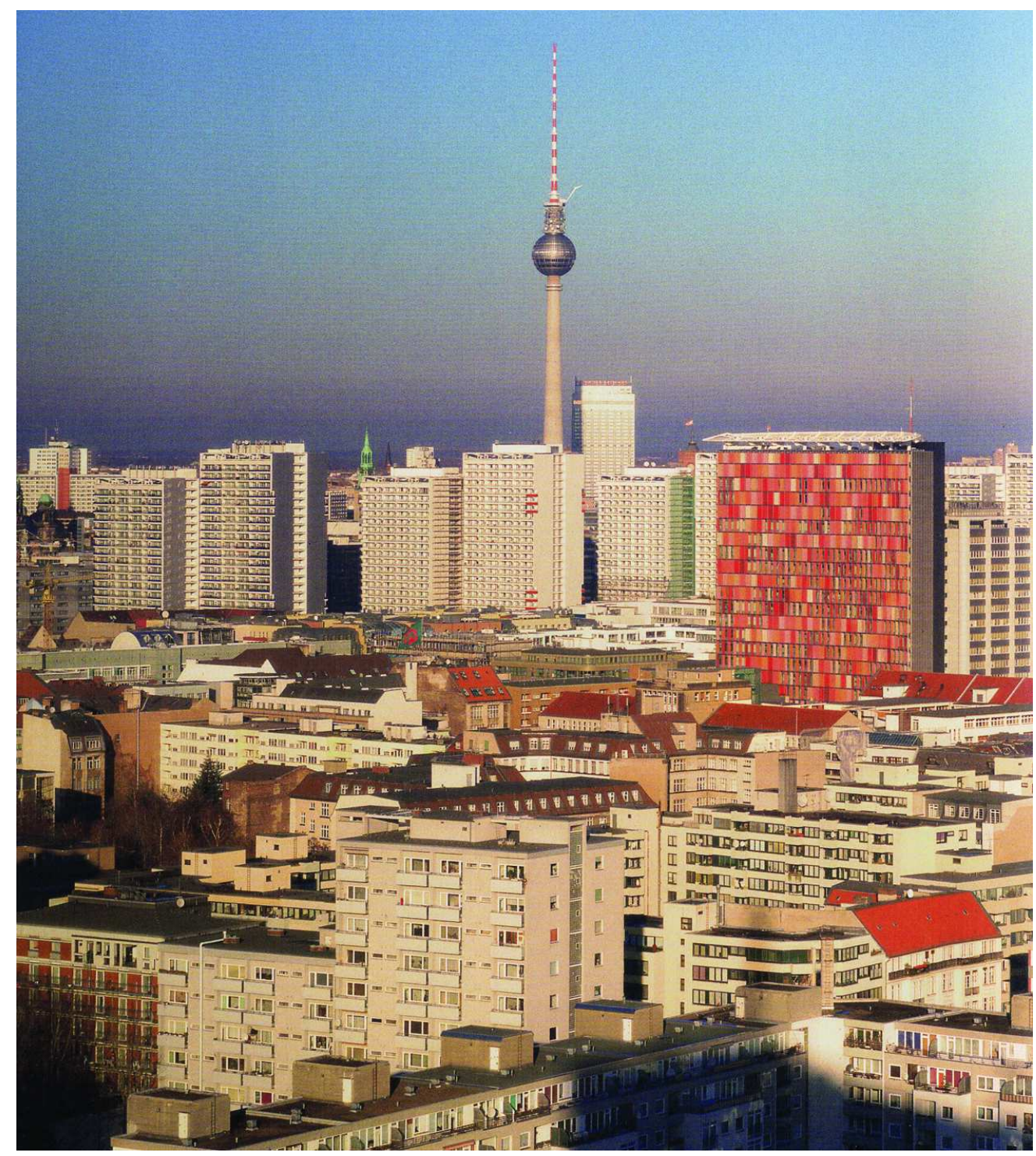

Fig. 7. GSW Headquarters, Sauerbruch \& Hutton architects, Berlín, 1991-1999. Courtesy Stucio Sauerbruch \& Hutton <http://www.sauerbruchhutton.de/> $105 \times 118 \mathrm{~mm}(300 \times 300$ DPI $)$ 


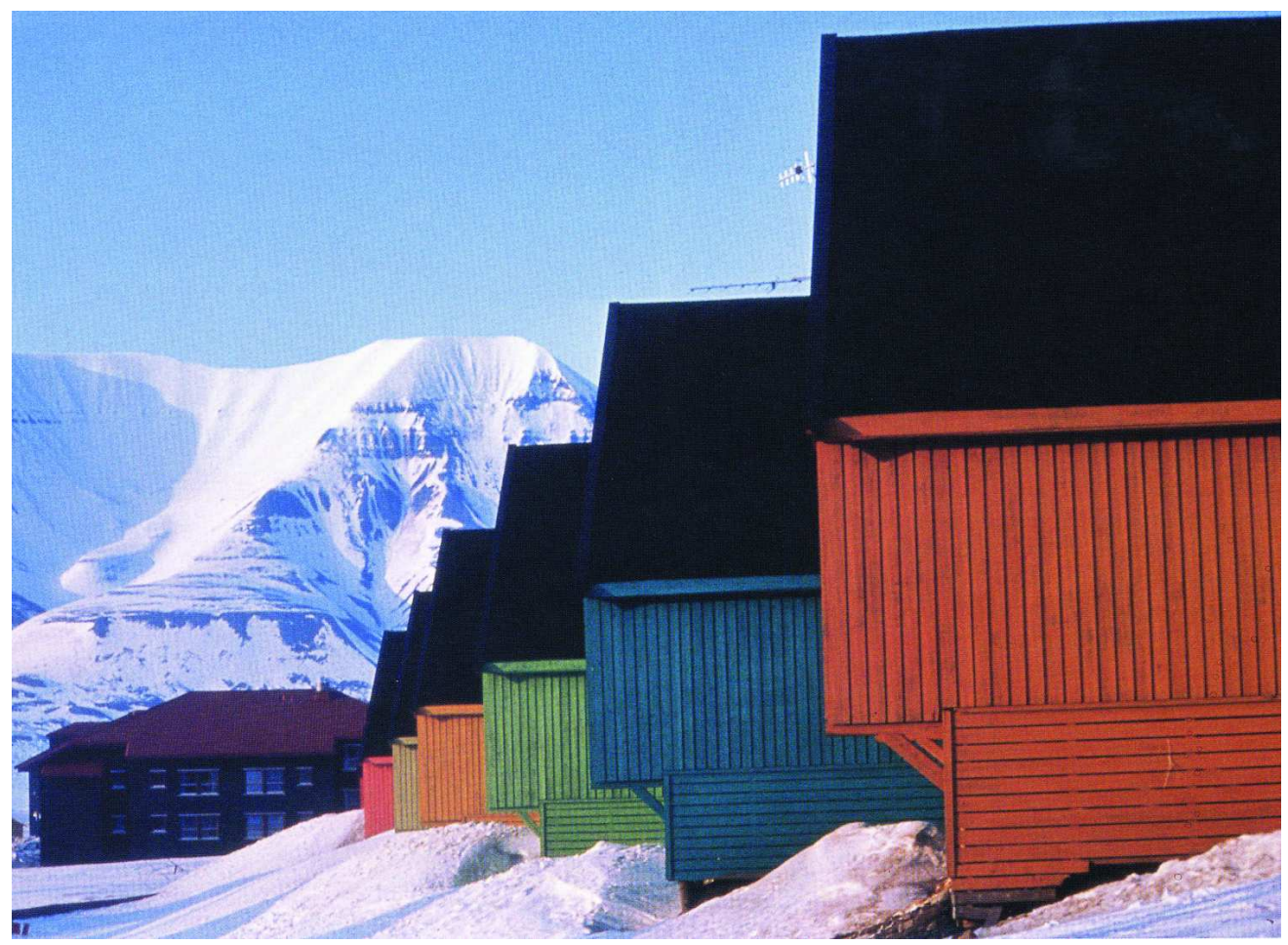

Fig. 8. Longeyearbyen Project, Grete Smedal, Longeyearbyen (Sweden), 1981. In: Porter T and Mikellides B, editors. Colour for architecture today. London: Taylor \& Francis; 2009. p 77. $127 \times 92 \mathrm{~mm}(300 \times 300 \mathrm{DPI})$ 


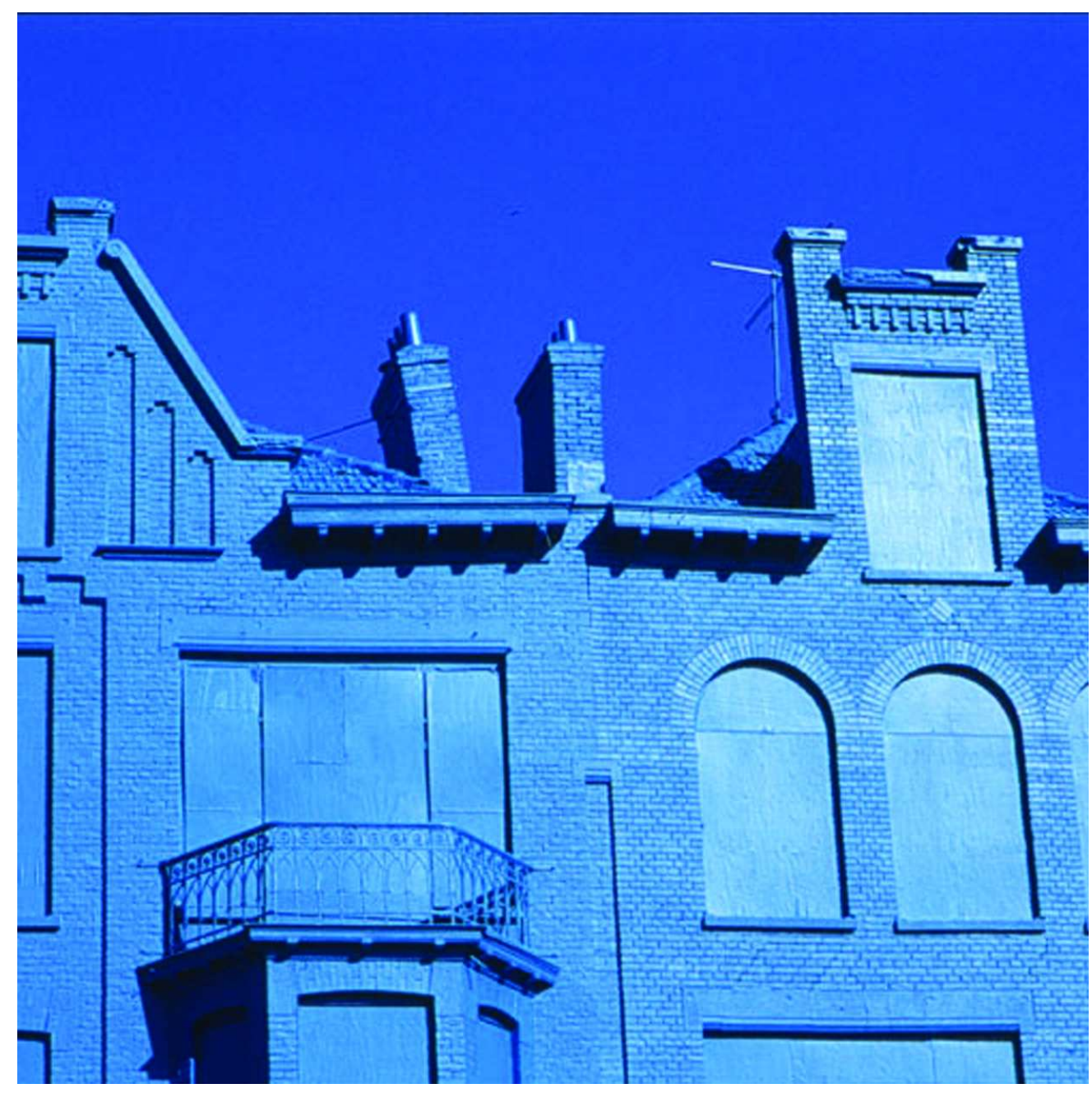

Fig. 9. Beukelsdijk, Florentijn Hoffman, Rotterdam (Holland), 2004-2006. In <http://www.florentijnhofman.nl/> $105 \times 105 \mathrm{~mm}(300 \times 300 \mathrm{DPI})$ 
Fig. 10. Scenic Space, MGM arquitects (José Morales, Sara Giles and Juan González), Nijar, Almería (Spain), 1998-2006. Photo by author. $127 \times 80 \mathrm{~mm}(300 \times 300$ DPI $)$ 


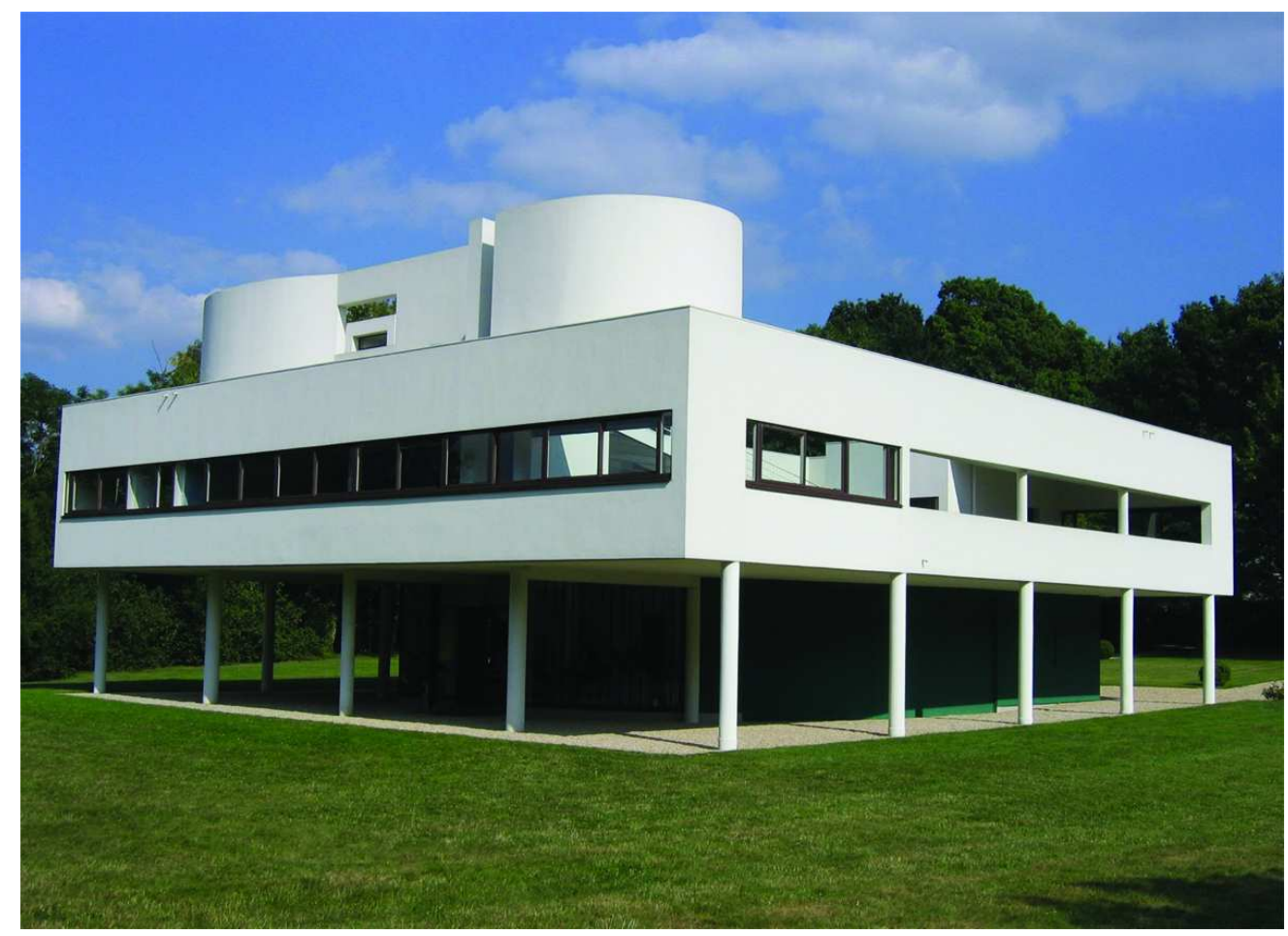

Fig. 11. Ville Saboye. Le Corbusier, Poissy (Francia), 1929-1931. Detalle de la planta baja de la villa, coloreada de verde para confundirse con el contexto. In <http://www.flickr.com/photos/yisris/267935008/>

$$
101 \times 73 \mathrm{~mm}(300 \times 300 \text { DPI) }
$$




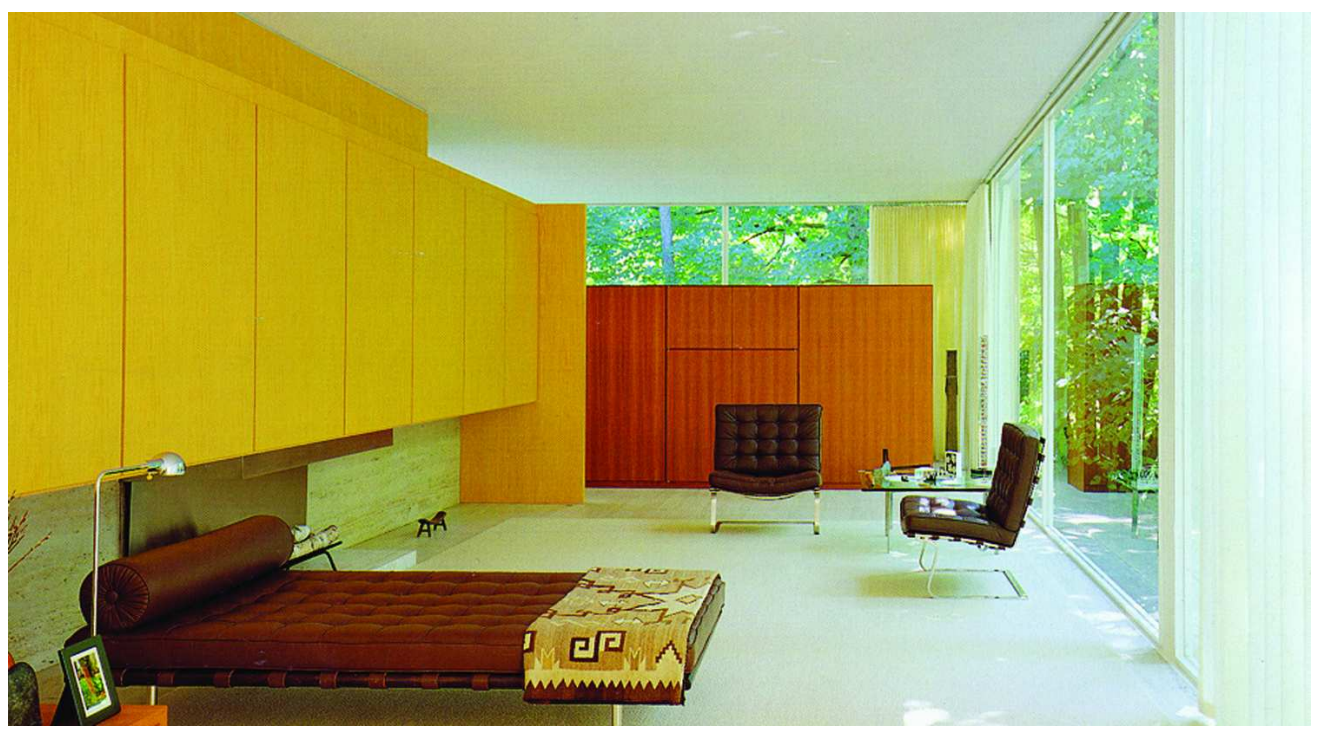

Fig. 12. Farnsworth House, Mies van der Rohe, Piano, Illimois (USA), 1946-1951. In: Blaser W. Ludwig Mies Van Der Rohe. Barcelona: Gustavo Gili, 1991. $127 \times 69 \mathrm{~mm}(300 \times 300 \mathrm{DPI})$ 
Fig. 13. Depuratore Milano Sud, Jorrit Tornquist, Milano, 2004. In: Tornquist J. Colore e luce: Teoria e Pratica; 3rd ed. Milano: Istituto del colore, 2005. p 306.

$123 \times 26 \mathrm{~mm}(300 \times 300 \mathrm{DPI})$ 


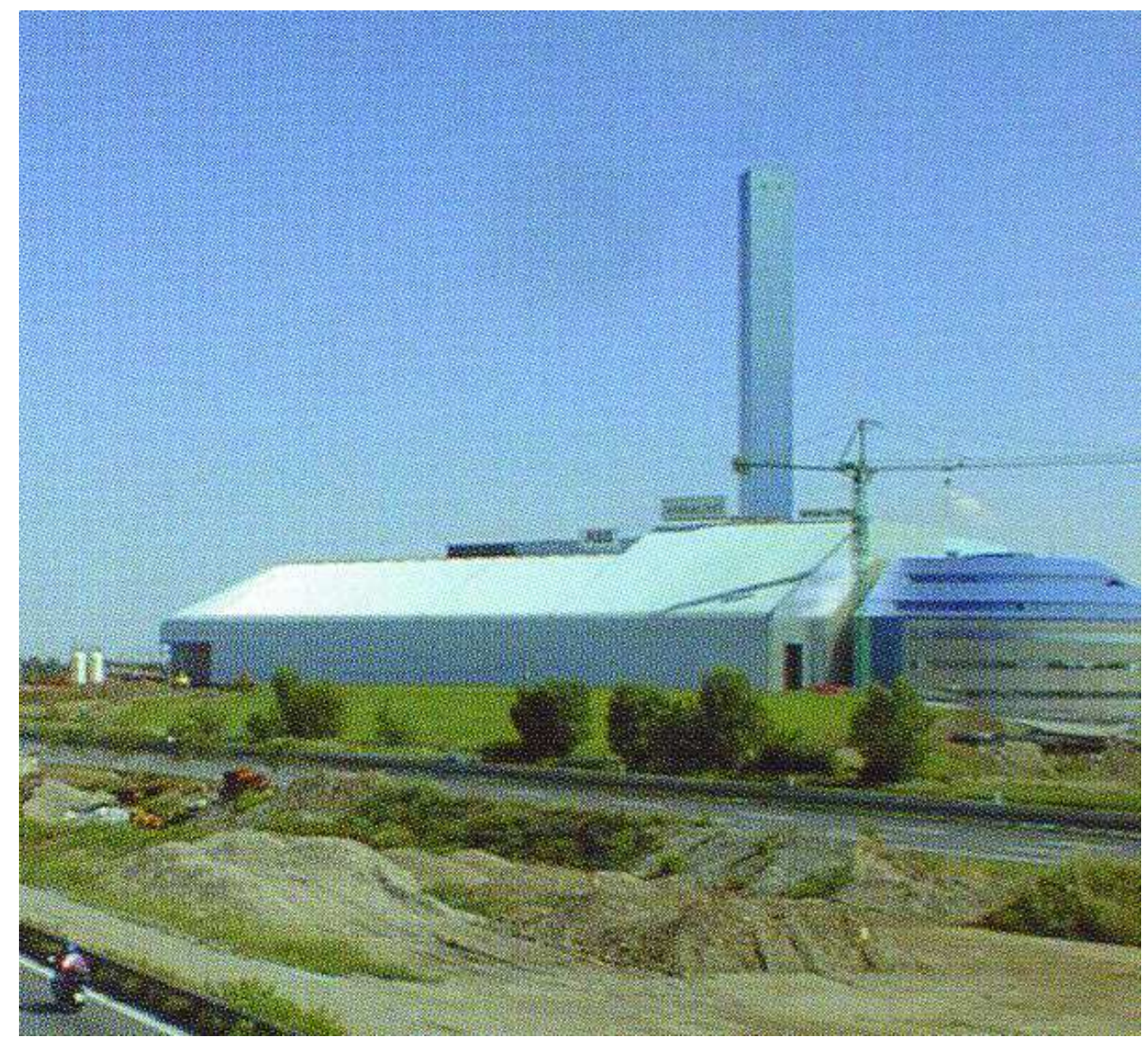

Fig. 14. Project Termoutilizzatore di Brescia, Jorrit Tornquist, Brescia (Italy), 1997-1998. In: Tornquist J. Colore e luce: Teoria e Pratica; 3rd ed. Milano: Istituto del colore, 2005. p 109. $50 \times 46 \mathrm{~mm}(300 \times 300$ DPI) 


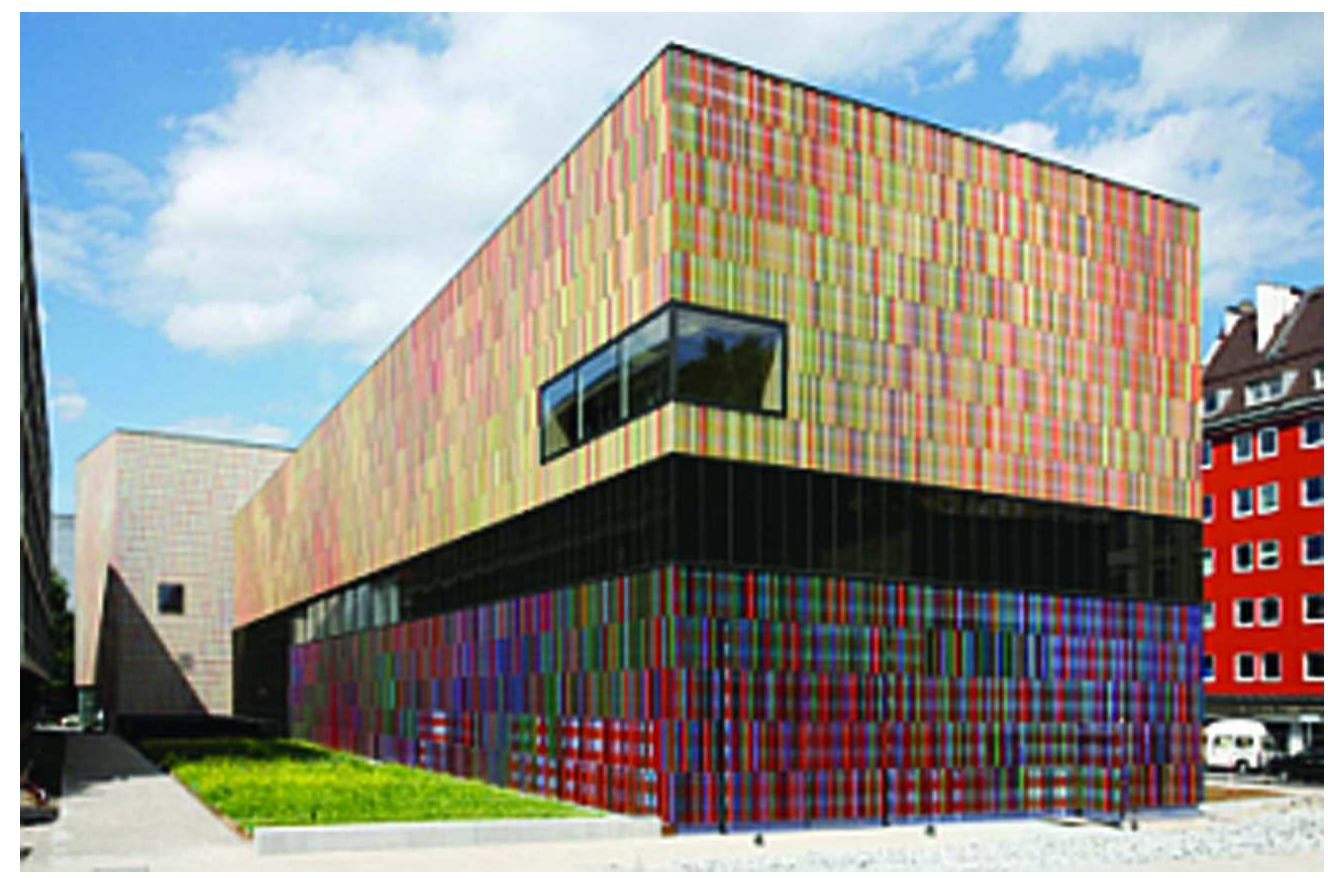

Fig. 15. Brandhorst' s Museum, Sauerbruch \& Hutton, Munich, 2002-2007. In $<$ http://blog.bellostes.com/> $110 \times 72 \mathrm{~mm}(300 \times 300$ DPI $)$ 


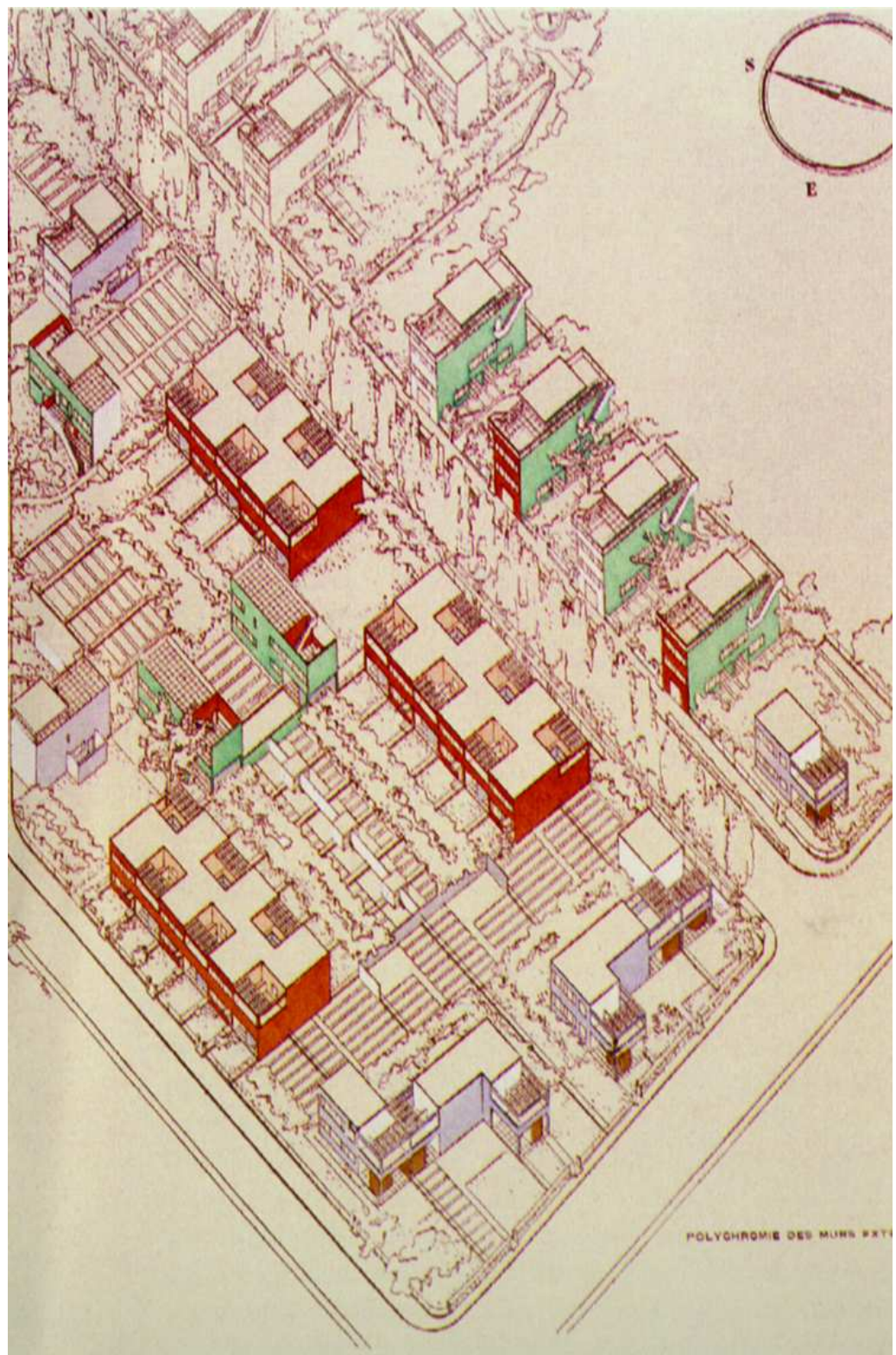

Fig. 16. Quartier Modernes Frugès, Le Corbusier, Pessac (France), 1924-1926. In : Noury L. La couleur dans la ville. Thouard V, editor. 1st ed. Paris: Moniteur (Départment Architecture); 2008. p 46.

$63 \times 96 \mathrm{~mm}(300 \times 300 \mathrm{DPI})$ 
Fig. 17. Laban Center, Herzog y de Meuron, London, 2002. In: VIA Arquitrecture: colour. Valencia: COACV, Colegio Oficial de Arquitectos de la Comunidad Valenciana; 2003. p 91

$127 \times 56 \mathrm{~mm}(300 \times 300 \mathrm{DPI})$ 
Fig. 18. Stralsund shipyard, Friedrich Ernst von Garnier, Stralsund (Germany), 1999. Photo courtesy Stucio Ernst Von Garnier <http://www.studiovongarnier.de/> $61 \times 16 \mathrm{~mm}(300 \times 300 \mathrm{DPI})$ 


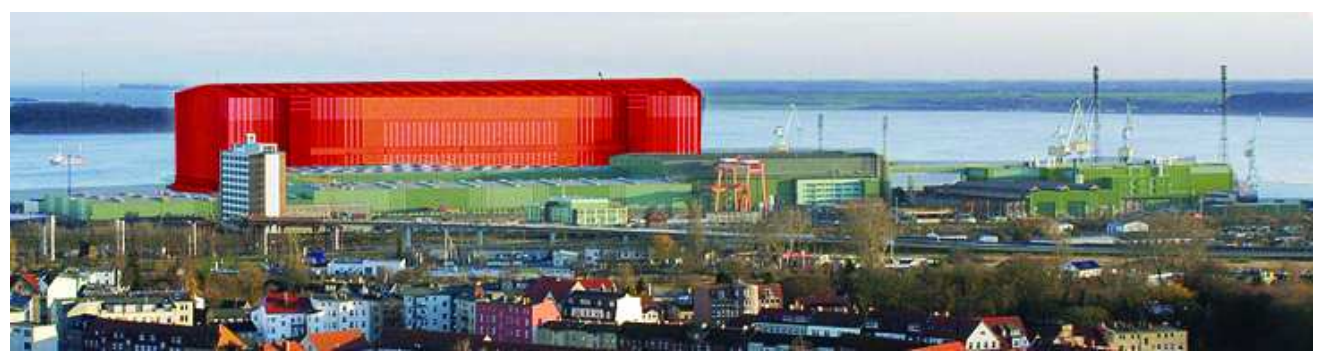

Fig. 19. Stralsund shipyard, photomontage by the author. $61 \times 16 \mathrm{~mm}(300 \times 300 \mathrm{DPI})$ 


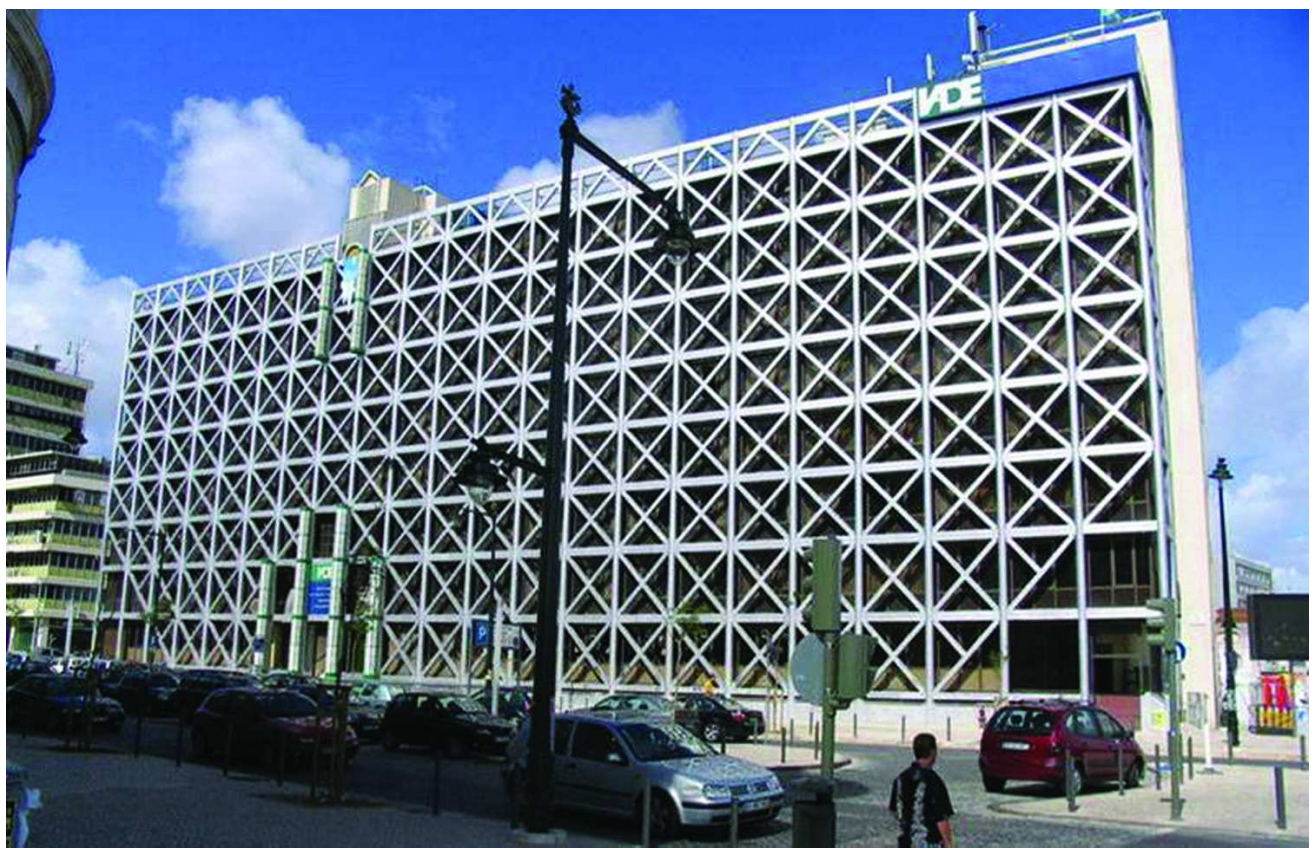

Fig. 20. Totovola Building (IADE), Tomás Taveira, Lisbon (Portugal), 1973-1984. $127 \times 81 \mathrm{~mm}(300 \times 300$ DPI $)$ 


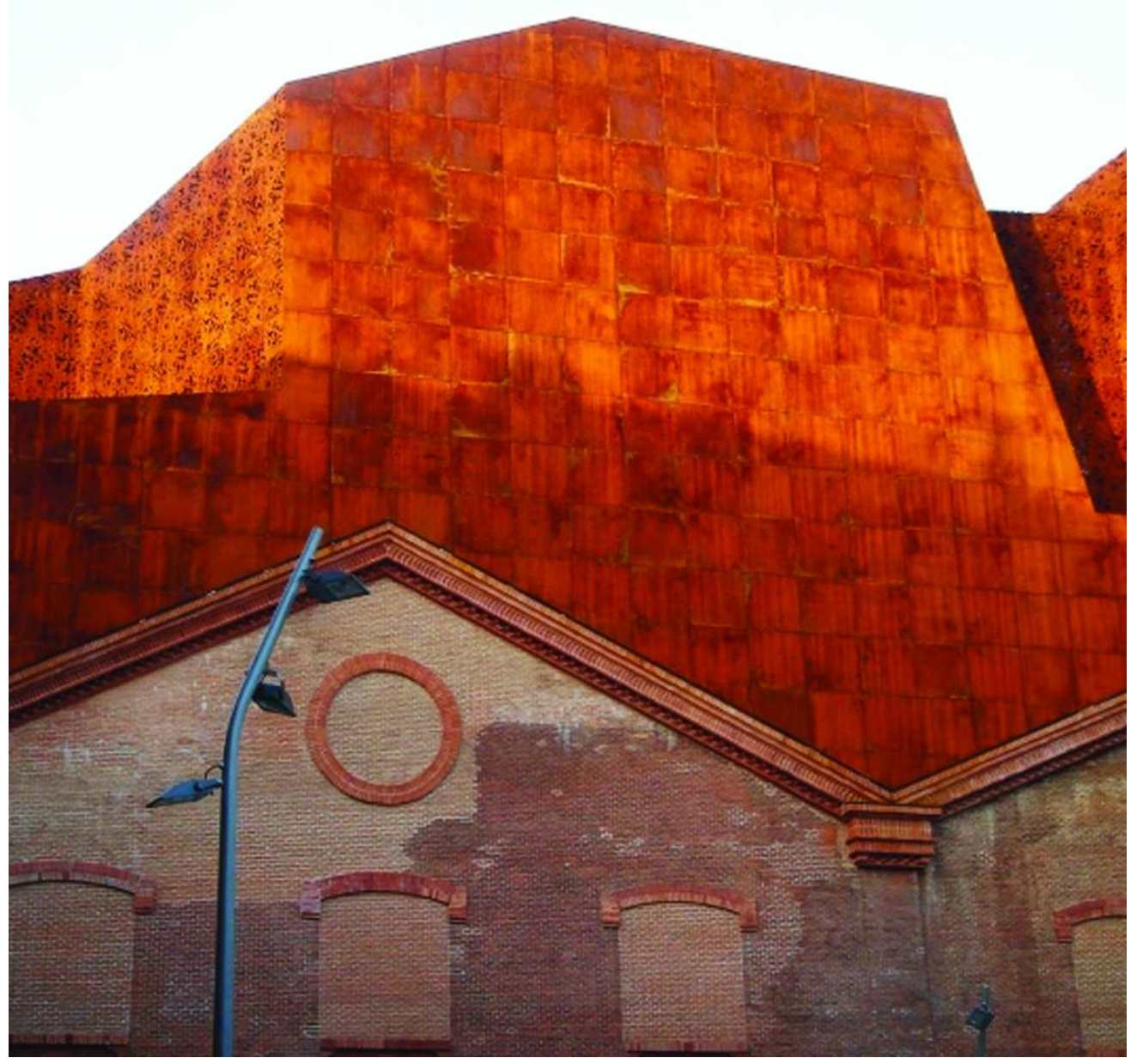

Fig. 21. Caixa-Forum Building, Herzog \& de Meuron, Madrid, 2008. Photo in Public Gallery IMAR, Author Miguel de Guzmán, http://blog.bellostes.com/?s=herzog+y+de+meuron $93 \times 93 \mathrm{~mm}(300 \times 300 \mathrm{DPI})$ 


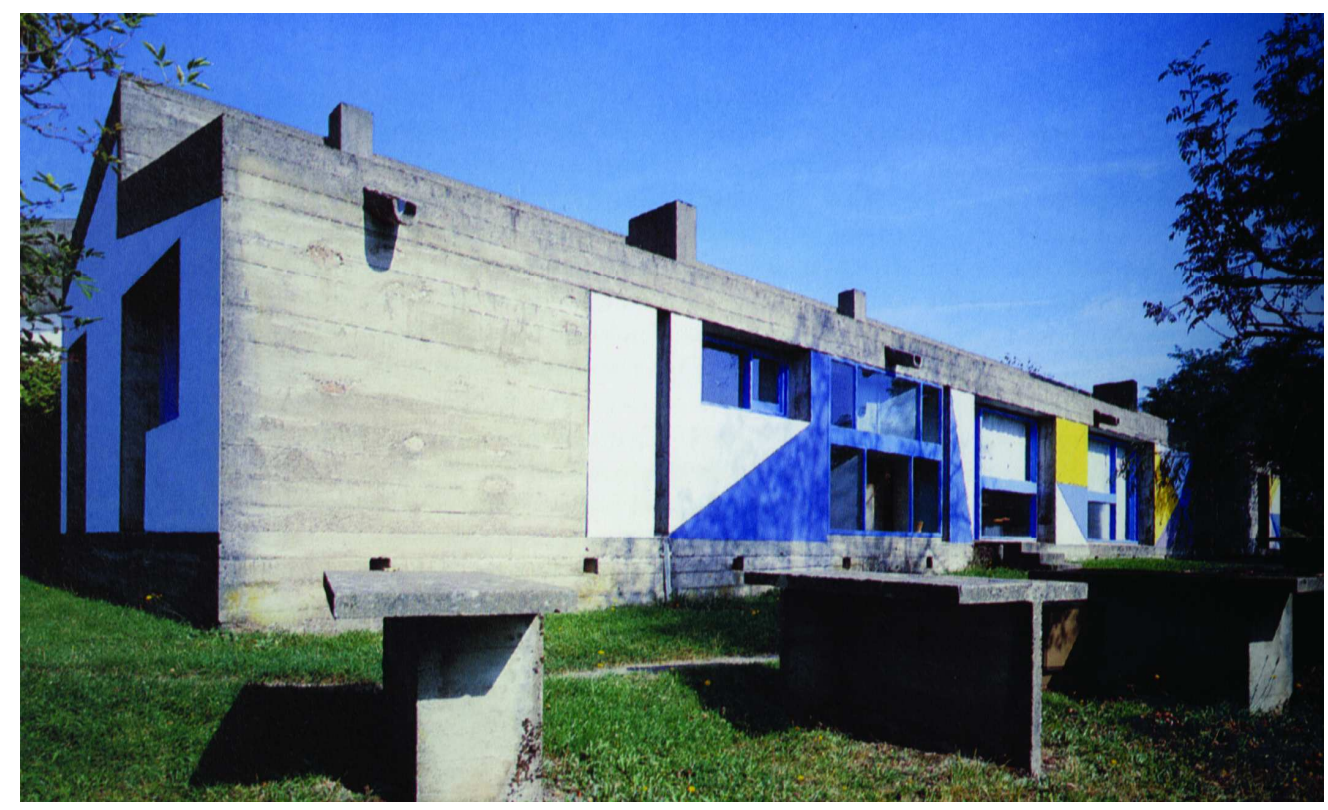

Fig. 22. Maison des Pèlerins, Le Corbusier, Ronchamp, France, 1950-55. $180 \times 109 \mathrm{~mm}$ (300 x 300 DPI) 


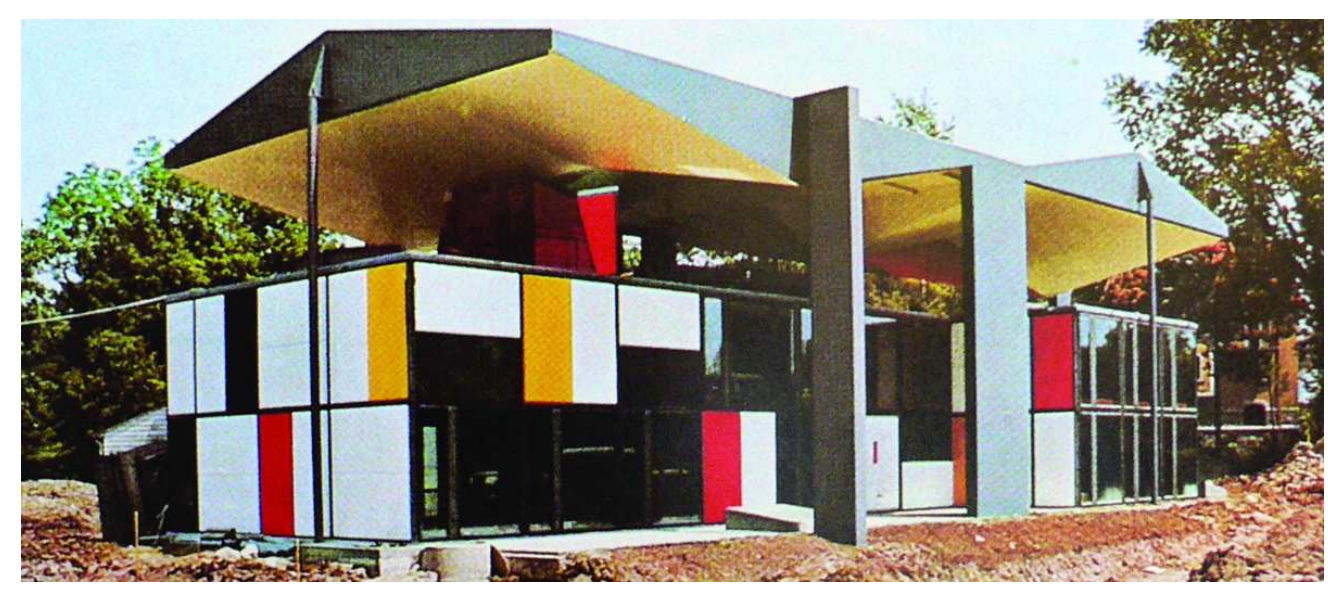

Fig. 23. Heidi Weber Pavilion, Le Corbusier, Zurich, 1965. $101 \times 43 \mathrm{~mm}$ (300 x 300 DPI) 


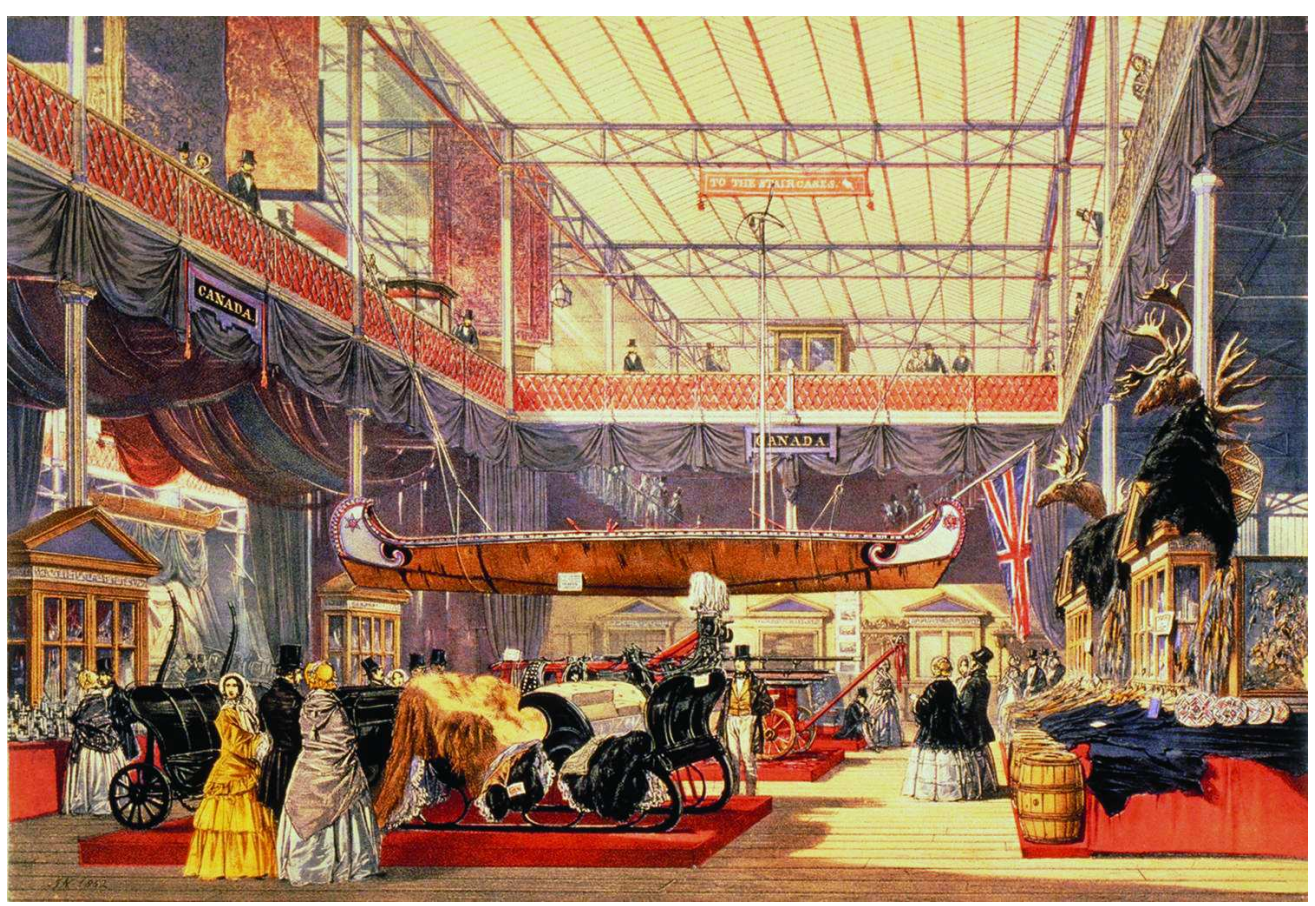

$127 \times 86 \mathrm{~mm}(300 \times 300$ DPI $)$ 


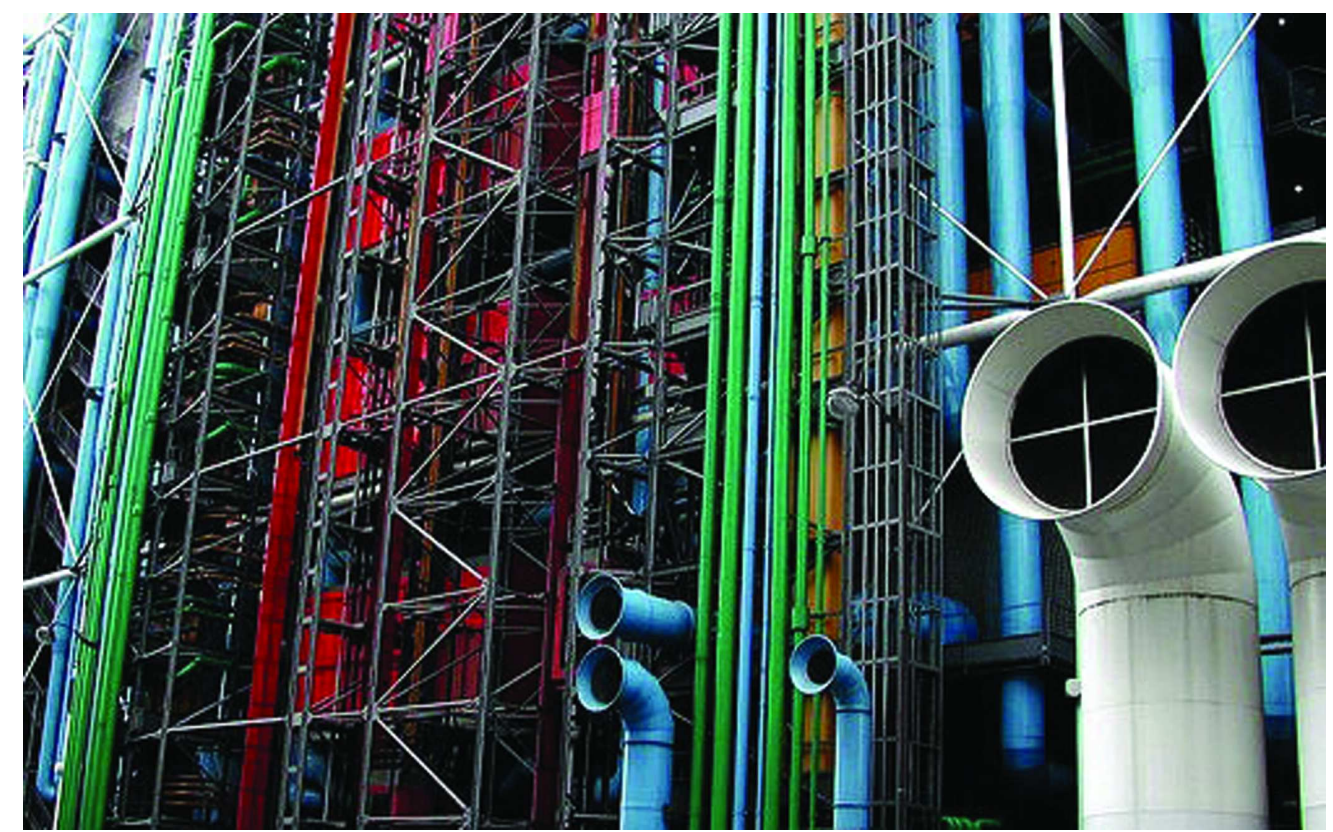

Fig. 25. George Pompidou Arts Centre, Richard Rogers and Renzo Piano, Paris, 1971-1977. $176 \times 110 \mathrm{~mm}(300 \times 300 \mathrm{DPI})$ 


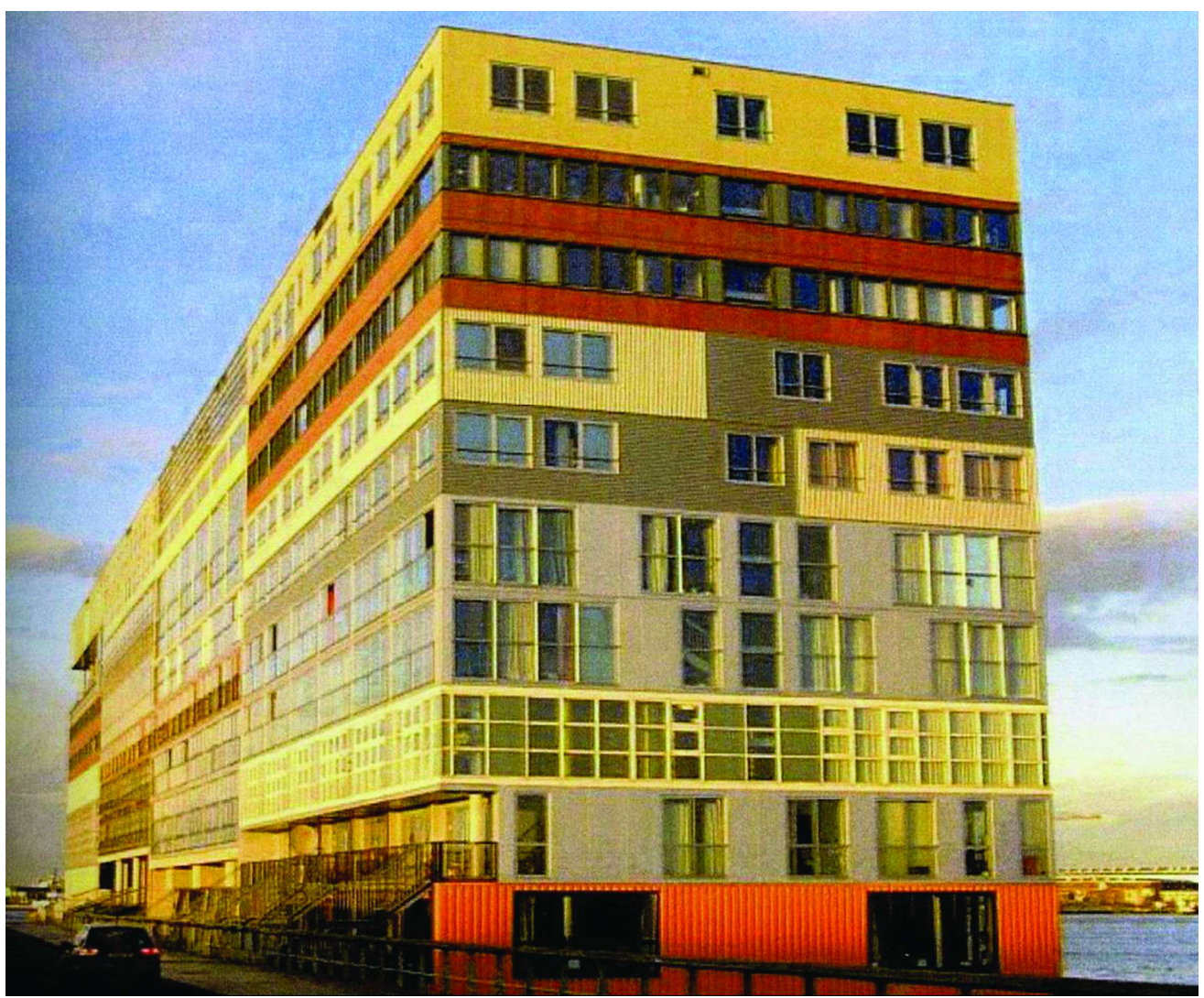

$195 \times 161 \mathrm{~mm}(300 \times 300 \mathrm{DPI})$ 


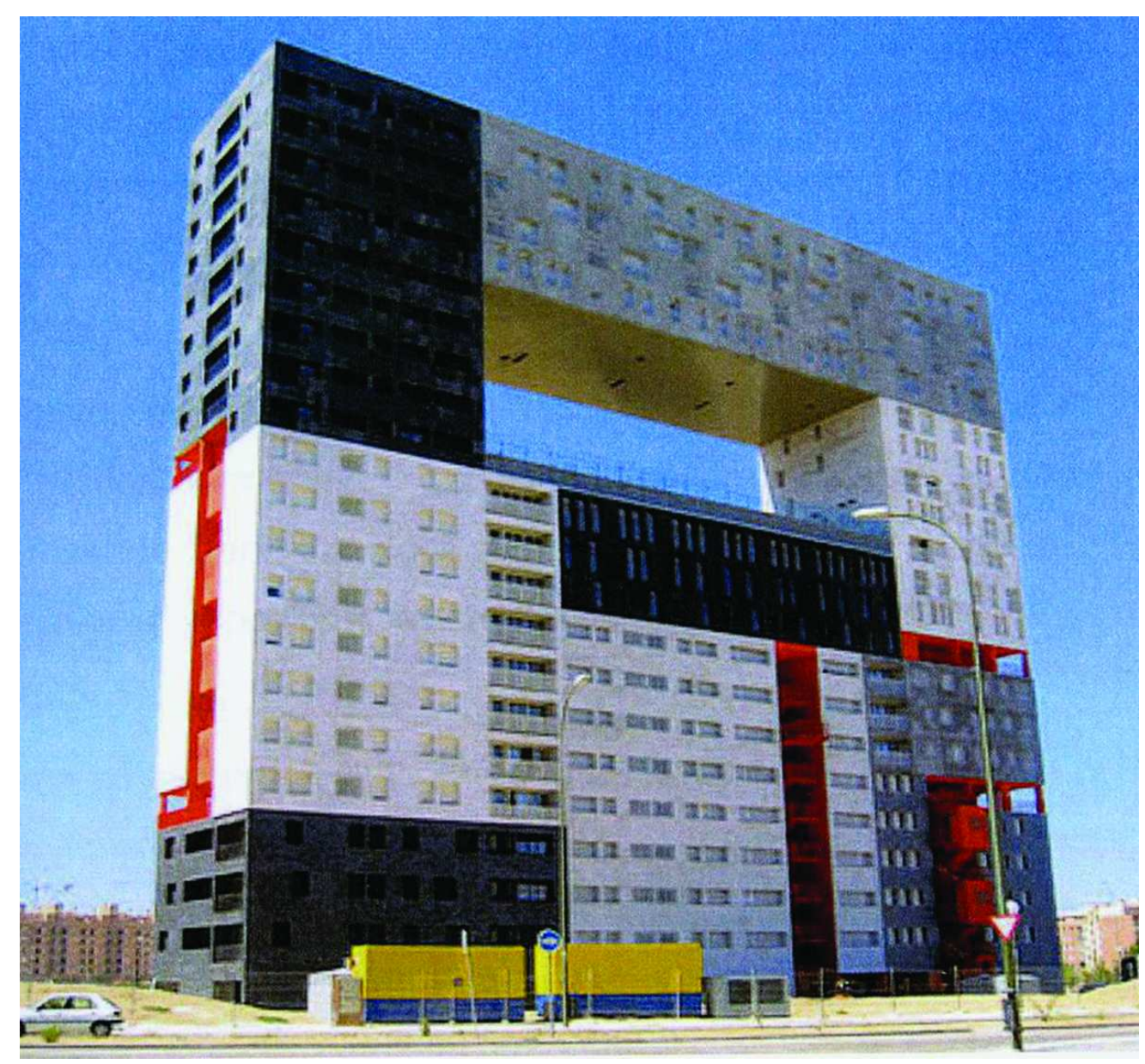

Fig. 27. Mirador Building. MVRDVarchitects, Madrid, 2004. Courtesy MVRDV architects http://www.mvrdv.nl/ $101 \times 94 \mathrm{~mm}(300 \times 300 \mathrm{DPI})$ 


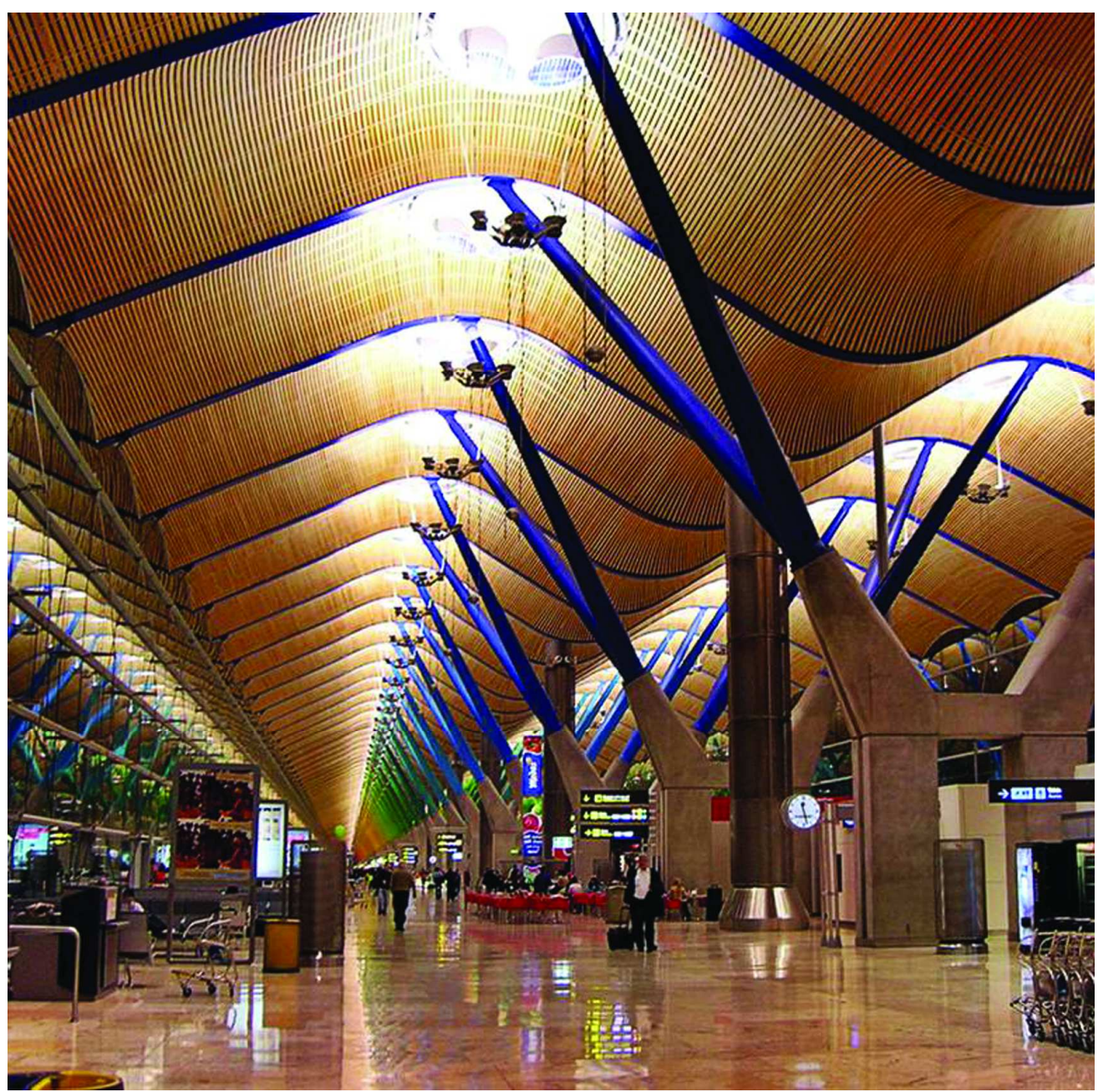

Fig. 28. Terminal T5 at Barajas Airport, Richard Rogers Partnership, Madrid, 2005. $144 \times 143 \mathrm{~mm}(300 \times 300 \mathrm{DPI})$ 


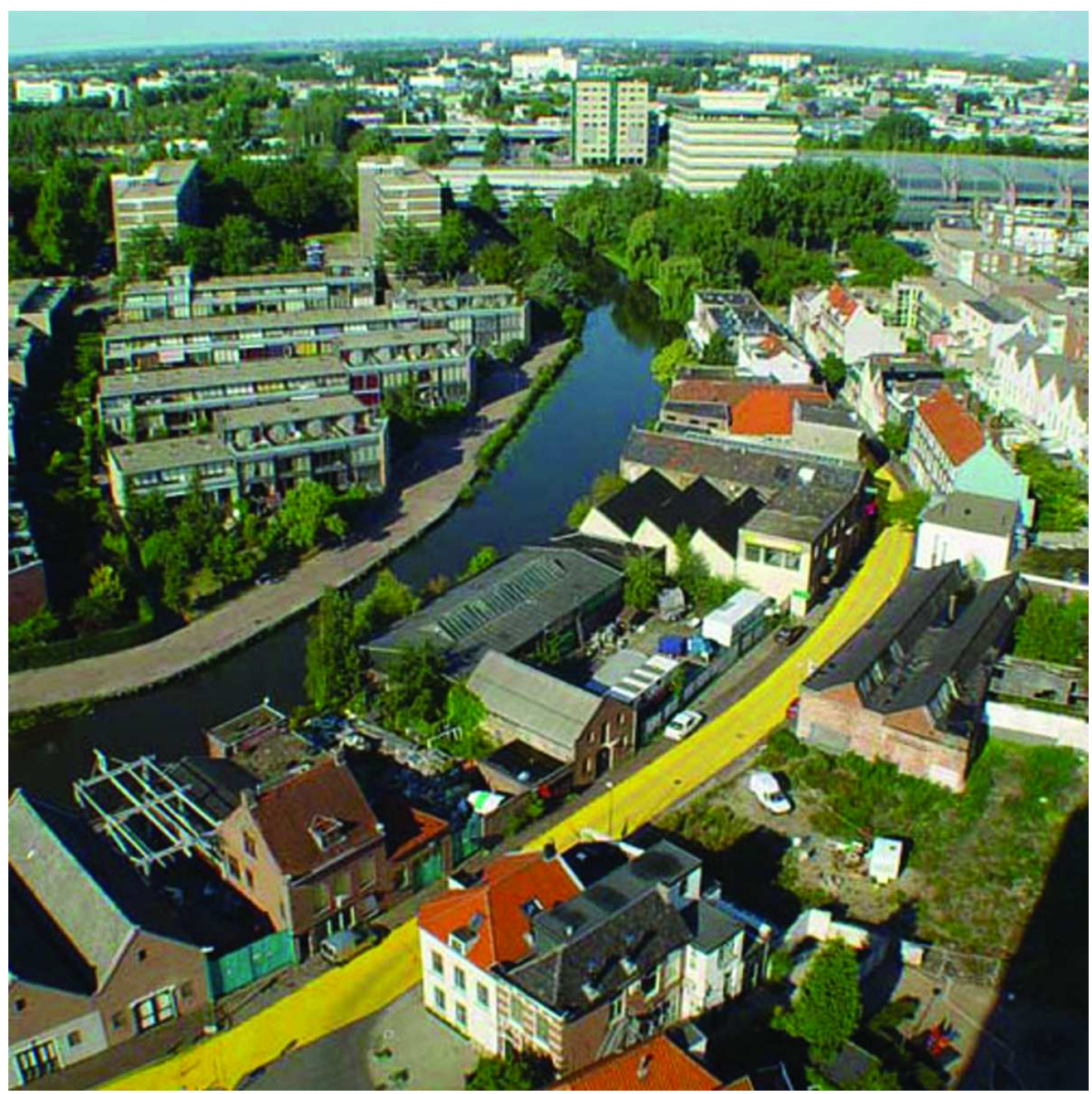

Fig. 29. Yellow Street (Overschiesestraat), Florentijn Hofman, Schiedam, Netherland; 2003. In <http://www.florentijnhofman.nl/> $101 \times 101 \mathrm{~mm}(300 \times 300 \mathrm{DPI})$ 


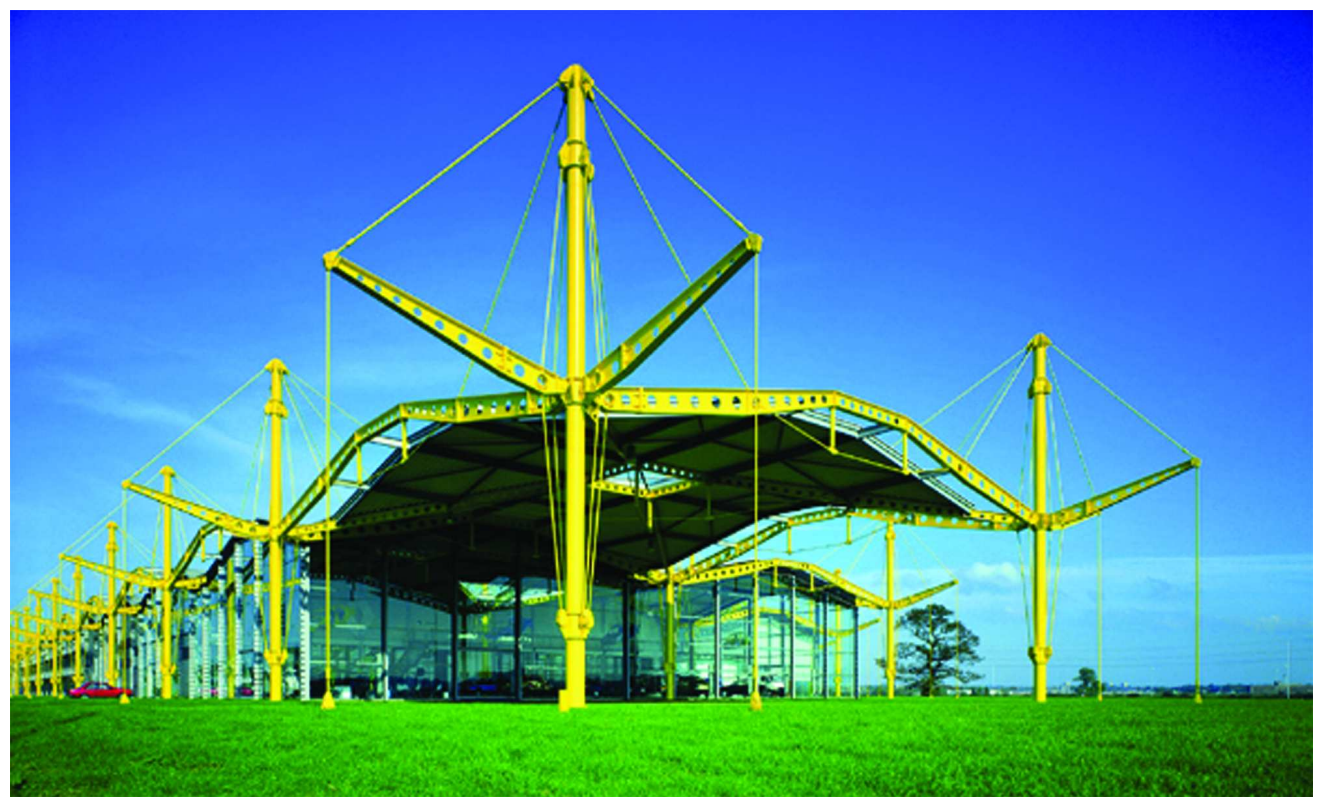

Fig. 30. Renault Centre, N. Foster, Swindon, England, 1982. In $<$ http://www.fosterandpartners.com/> 


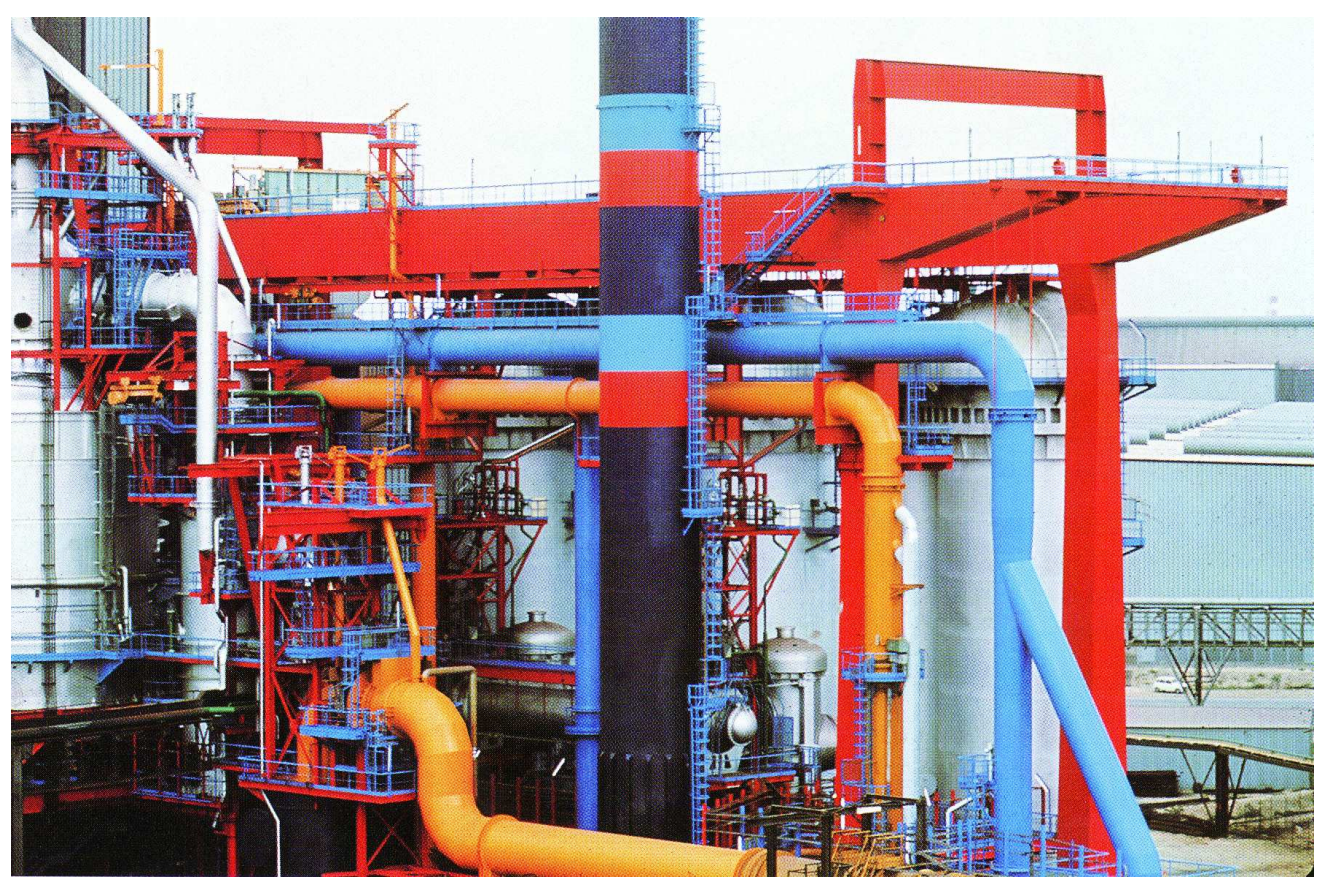

Fig. 31. Solmer Steelworks, Jean Philipe Lenclos, Fos Sur Mer, Marseille (France). In: Linton H. Color in Architecture : Design Methods for Buildings, Interiors, and Urban Spaces. New York \& London: Ed. McGraw-Hill, 1999. pp 267. $151 \times 99 \mathrm{~mm}(300 \times 300 \mathrm{DPI})$ 


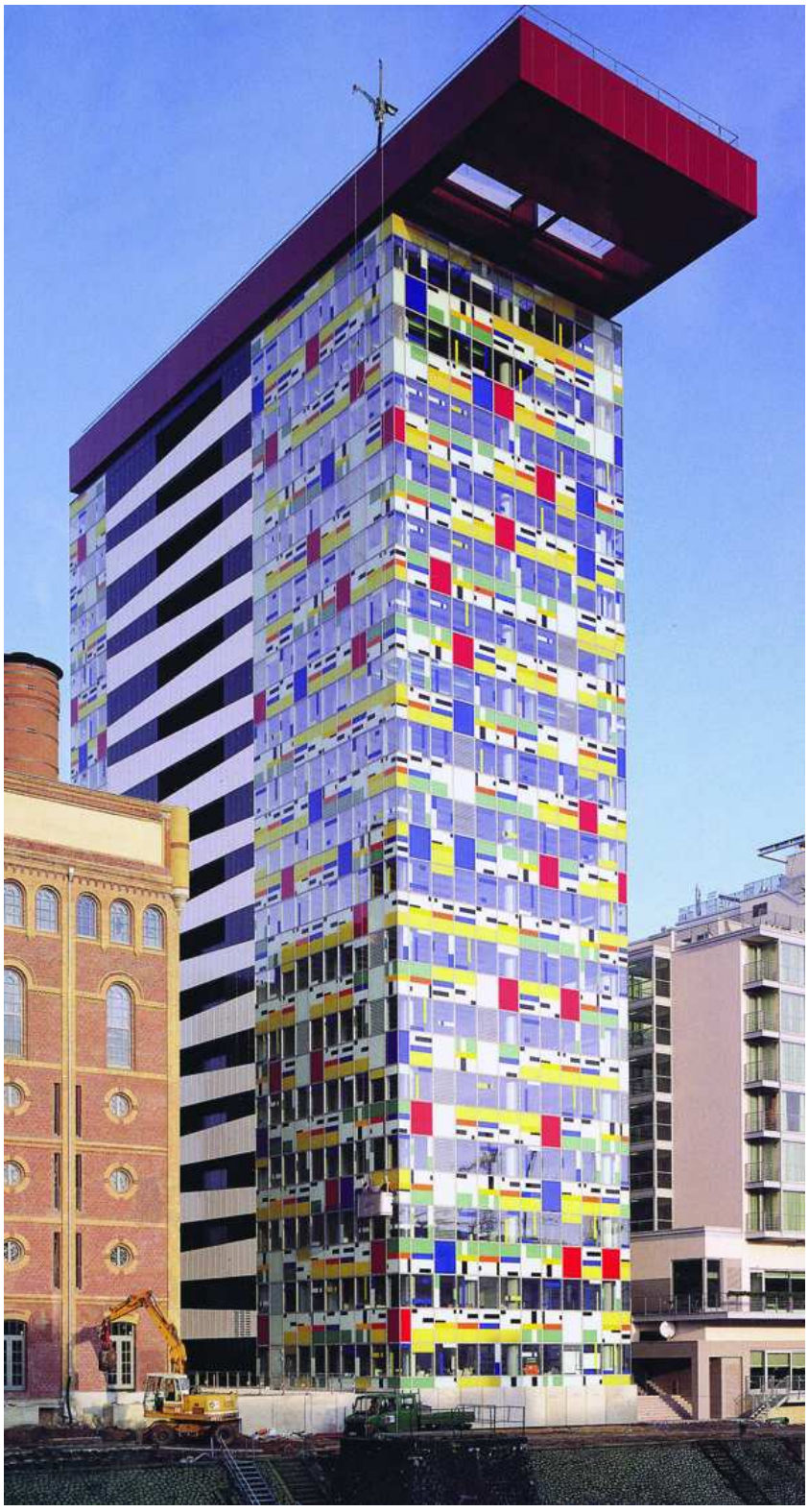

Fig. 32. Colorium, William Alsop, Dusseldorf, Germany, 2001. $50 \times 94 \mathrm{~mm}(300 \times 300 \mathrm{DPI})$ 


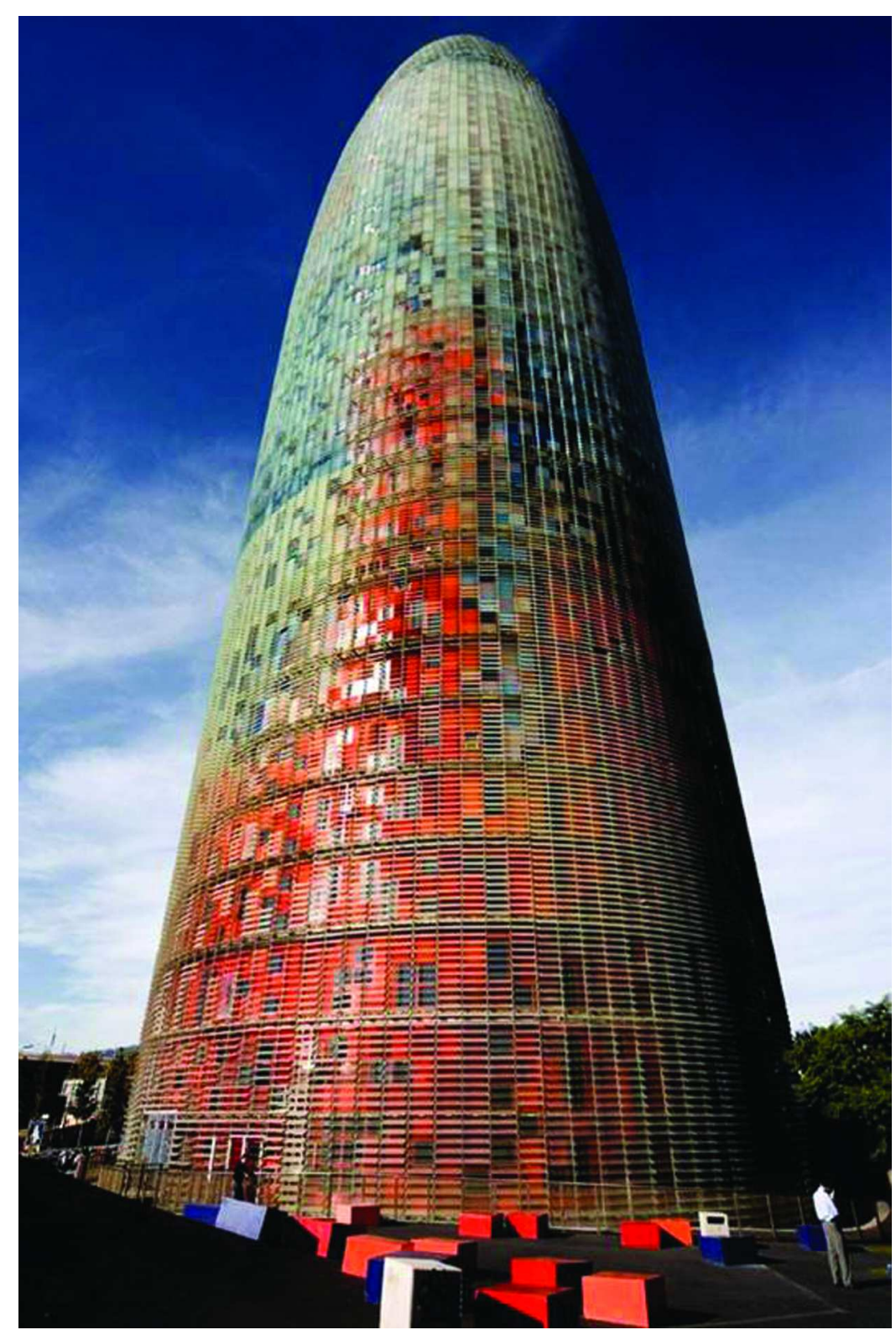

Fig. 33. Agbar Tower, Jean Nouvel, Barcelona, Spain, 2007. $106 \times 159 \mathrm{~mm}$ (300 x $300 \mathrm{DPI})$ 
Fig. 34. MUSAC Contemporary Arts Museum, Emilio Tuñón and Luis Moreno Mansilla, León (Spain), 2004. In: Meyhöfer D. In Full Colour: Recent Buildings and Interiors. Berlin: Ed. Verlagshaus Braun; 2008. p 125.

$126 \times 113 \mathrm{~mm}(300 \times 300 \mathrm{DPI})$ 


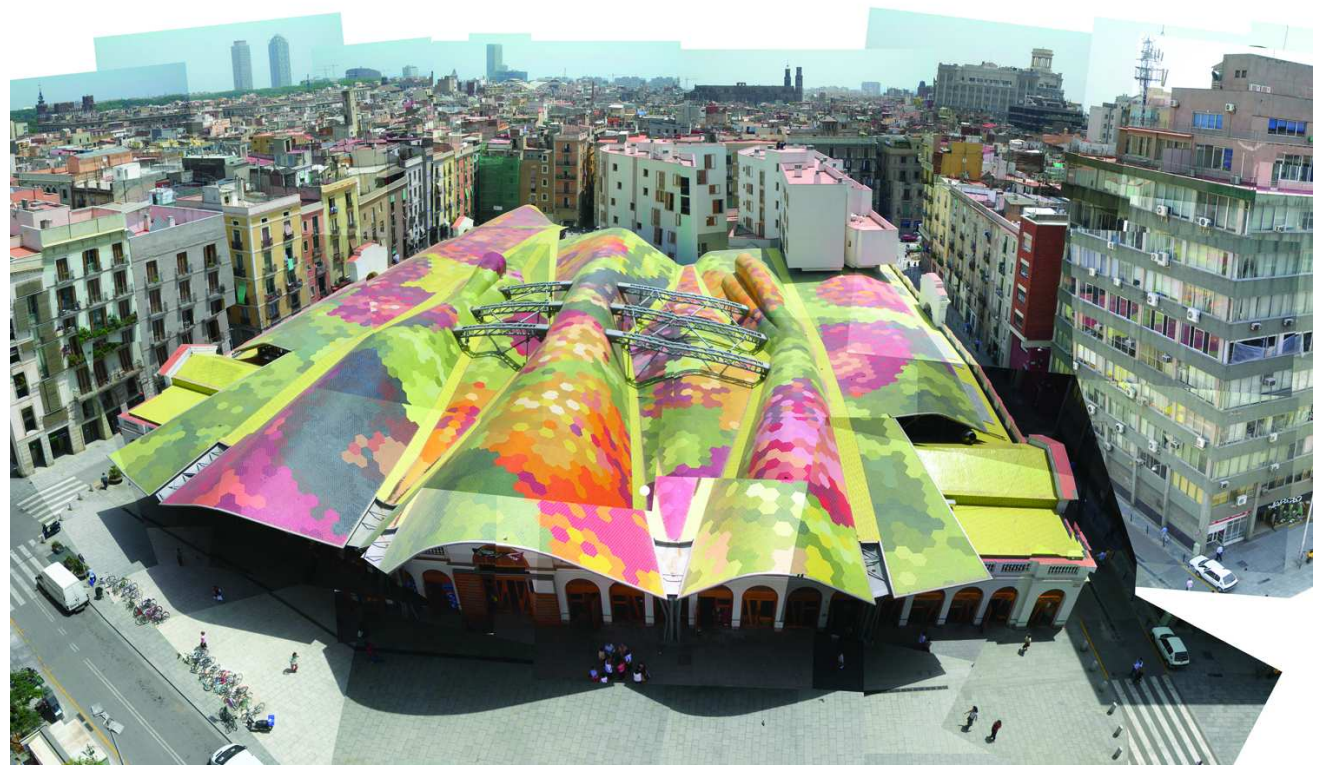

Fig. 35. Santa Caterina Market, EMBT architects (Enric Miralles and Benedetta Tagliabue), Barcelona, Spain, 1997-2004. Photo courtesy Benedetta Tagliebue and Salvador Gilabert. $127 \times 78 \mathrm{~mm}(300 \times 300 \mathrm{DPI})$ 


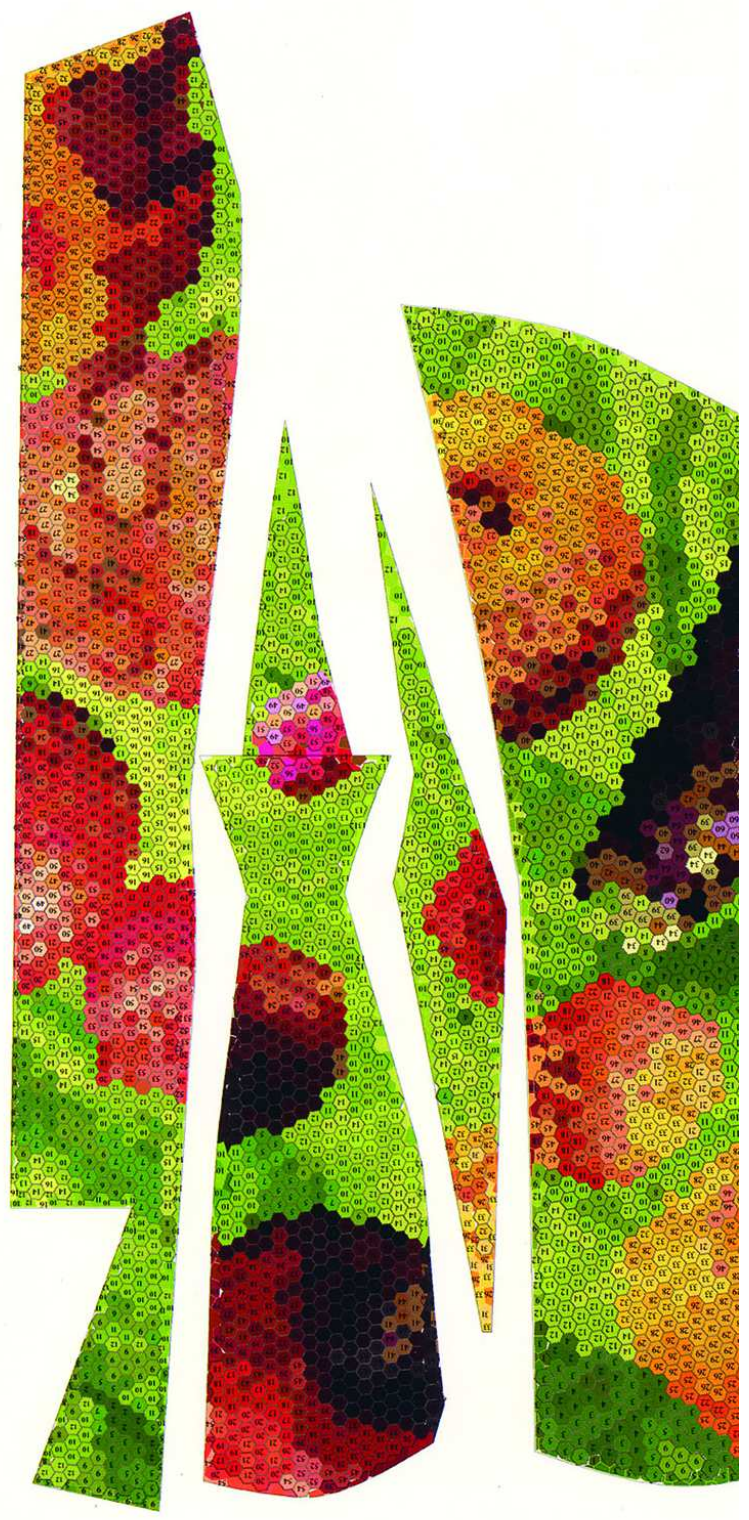

Fig. 36. Collage for Santa Caterina Market roof. Photo courtesy Benedetta Tagliebue and Salvador Gilabert. $63 \times 129 \mathrm{~mm}(300 \times 300 \mathrm{DPI})$ 


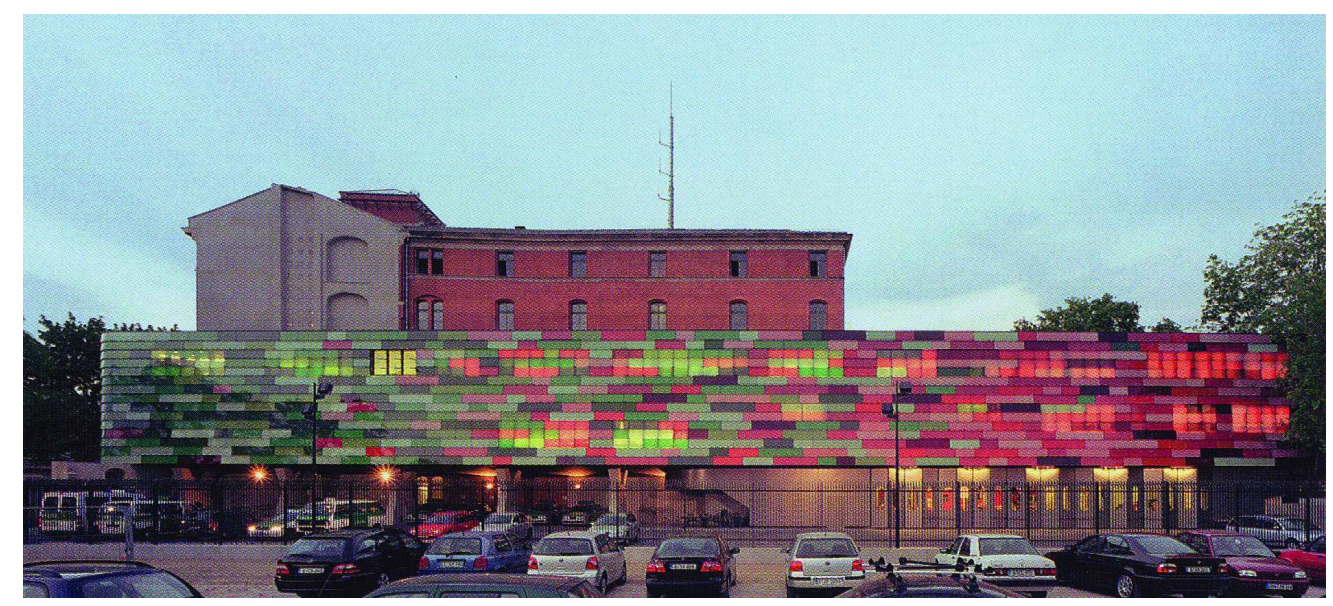

Fig. 37. Fire and Police station, Sauerbruch \& Hutton, Berlin, 1999/ 2004. Courtesy Stucio Sauerbruch \& Hutton <http://www.sauerbruchhutton.de/> $133 \times 60 \mathrm{~mm}(360 \times 360 \mathrm{DPI})$ 